Prepared in cooperation with the Arkansas Natural Resources Commission and the Arkansas Geological Survey

\title{
Water Levels and Water Quality in the Mississippi River Valley Alluvial Aquifer in Eastern Arkansas, 2012
}

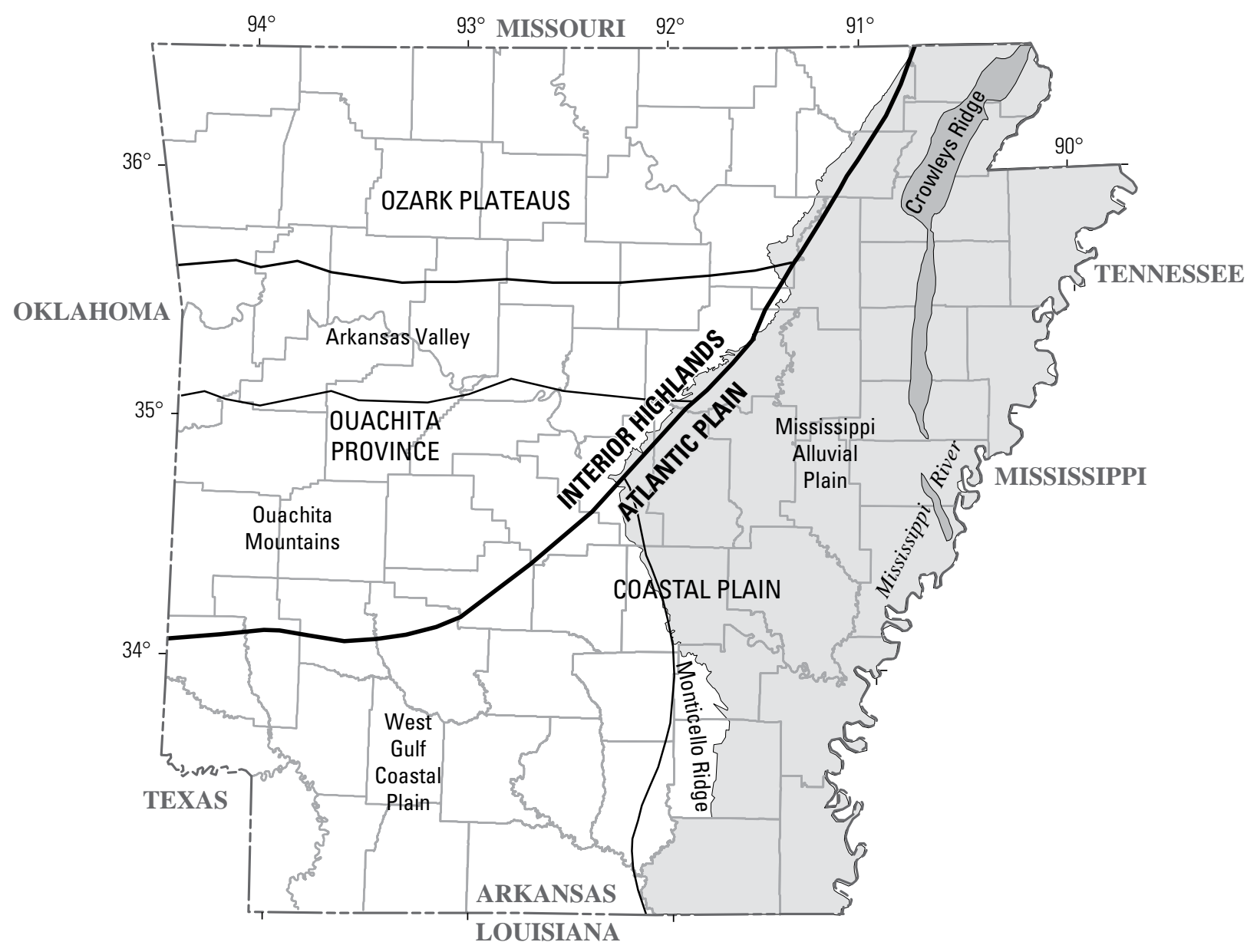

Scientific Investigations Report 2015-5059 



\section{Water Levels and Water Quality in the Mississippi River Valley Alluvial Aquifer in Eastern Arkansas, 2012}

By T.P. Schrader

Prepared in cooperation with the Arkansas Natural Resources Commission and the Arkansas Geological Survey

Scientific Investigations Report 2015-5059 


\title{
U.S. Department of the Interior SALLY JEWELL, Secretary
}

\section{U.S. Geological Survey \\ Suzette M. Kimball, Acting Director}

\author{
U.S. Geological Survey, Reston, Virginia: 2015
}

For more information on the USGS - the Federal source for science about the Earth, its natural and living resources, natural hazards, and the environment—visit http://www.usgs.gov or call 1-888-ASK-USGS.

For an overview of USGS information products, including maps, imagery, and publications, visit http://www.usgs.gov/pubprod/.

Any use of trade, firm, or product names is for descriptive purposes only and does not imply endorsement by the U.S. Government.

Although this information product, for the most part, is in the public domain, it also may contain copyrighted materials as noted in the text. Permission to reproduce copyrighted items must be secured from the copyright owner.

Suggested citation:

Schrader, T.P., 2015, Water levels and water quality in the Mississippi River Valley alluvial aquifer in eastern Arkansas, 2012: U.S. Geological Survey Scientific Investigations Report 2015-5059, 63 p., 2 pls., http://dx.doi. org/10.3133/sir20155059.

ISSN 2328-031X (print)

ISSN 2328-0328 (online)

ISBN 978-1-4113-3923-1 


\section{Contents}

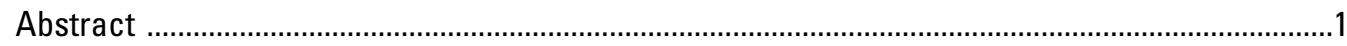

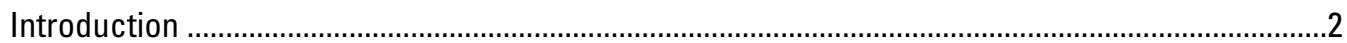

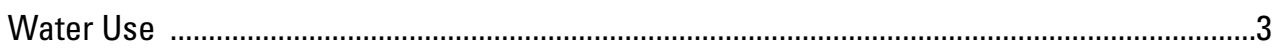

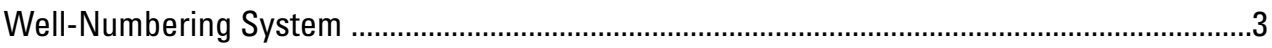

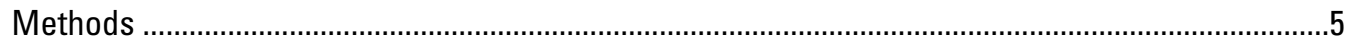

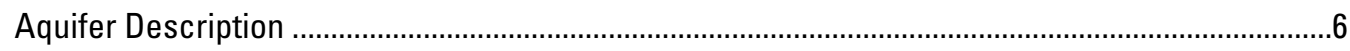

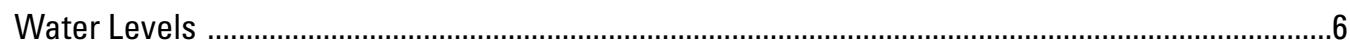

Potentiometric-Surface Map .........................................................................................

Water-Level Difference from 2008 to 2012 …………….....................................................

Long-Term Hydrographs ...............................................................................................

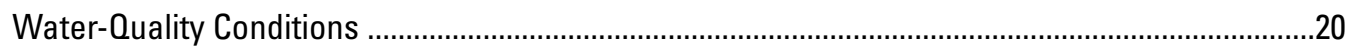

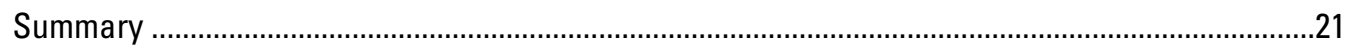

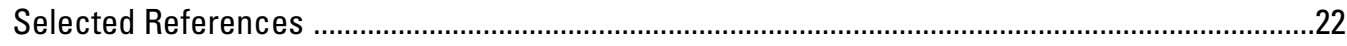

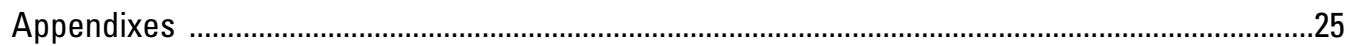

1. Water levels measured in wells completed in the Mississippi River Valley alluvial aquifer in eastern Arkansas, 2012 ....................................................................27

2. Difference in water levels measured from 2008 to 2012 in the Mississippi River Valley alluvial aquifer in eastern Arkansas ...................................................................4

3. Specific conductance, temperature, $\mathrm{pH}$, and chloride data from wells completed in the Mississippi River Valley alluvial aquifer in eastern Arkansas, summmer 2012

\section{Plates}

[In pocket]

1 Map showing potentiometric surface for the Mississippi River Valley alluvial aquifer in Arkansas, 2012

2 Map showing water-level difference for the Mississippi River Valley alluvial aquifer in Arkansas from 2008 to 2012

\section{Figures}

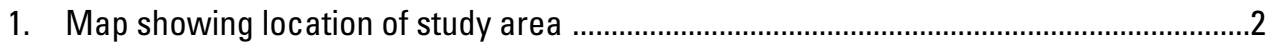

2. Graph showing water withdrawals from the Mississippi River Valley alluvial aquifer in Arkansas, 1965-2010 .............................................................................

3. Diagram showing well-numbering system ..............................................................

4. Water-level hydrographs for selected wells completed in the Mississippi River

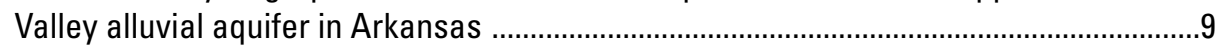

5. Graph showing distribution of specific conductance in samples from the Mississippi River Valley alluvial aquifer in Arkansas, 2012 


\section{Tables}

1. Range, mean, median, and correlation coefficient, $R^{2}$, of annual rise-decline in water level by county for wells in the Mississippi River Valley alluvial aquifer, 1988-2012 .......8

\section{Conversion Factors}

Inch/Pound to International System of Units

\begin{tabular}{|c|c|c|}
\hline Multiply & By & To obtain \\
\hline \multicolumn{3}{|c|}{ Length } \\
\hline foot $(\mathrm{ft})$ & 0.3048 & meter (m) \\
\hline mile (mi) & 1.609 & kilometer (km) \\
\hline \multicolumn{3}{|c|}{ Area } \\
\hline square mile $\left(\mathrm{mi}^{2}\right)$ & 2.590 & square kilometer $\left(\mathrm{km}^{2}\right)$ \\
\hline \multicolumn{3}{|c|}{ Flow rate } \\
\hline foot per year (ft/yr) & 0.3048 & meter per year (m/yr) \\
\hline gallon per minute (gal/min) & 0.06309 & liter per second (L/s) \\
\hline million gallons per day (Mgal/d) & 0.04381 & cubic meter per second $\left(\mathrm{m}^{3} / \mathrm{s}\right)$ \\
\hline
\end{tabular}

Temperature in degrees Celsius $\left({ }^{\circ} \mathrm{C}\right)$ may be converted to degrees Fahrenheit $\left({ }^{\circ} \mathrm{F}\right)$ as ${ }^{\circ} \mathrm{F}=\left(1.8 \times{ }^{\circ} \mathrm{C}\right)+32$.

\section{Datum}

Vertical coordinate information is referenced to the National Geodetic Vertical Datum of 1929 (NGVD 29).

Horizontal coordinate information is referenced to North American Datum of 1983 (NAD 83). Altitude, as used in this report, refers to distance above the vertical datum.

\section{Supplemental Information}

Specific conductance is given in microsiemens per centimeter at 25 degrees Celsius $(\mu \mathrm{S} / \mathrm{cm}$ at $\left.25^{\circ} \mathrm{C}\right)$.

Concentrations of chemical constituents in water are given either in milligrams per liter (mg/L) or micrograms per liter ( $\mu \mathrm{g} / \mathrm{L})$. 


\title{
Water Levels and Water Quality in the Mississippi River Valley Alluvial Aquifer in Eastern Arkansas, 2012
}

\author{
By T.P. Schrader
}

\section{Abstract}

During the spring of 2012, the U.S. Geological Survey, in cooperation with the Arkansas Natural Resources Commission and the Arkansas Geological Survey, measured water levels in 342 wells completed in the Mississippi River Valley alluvial aquifer in eastern Arkansas. The Arkansas Natural Resources Commission measured water levels in 11 wells, and the U.S. Department of Agriculture-Natural Resources Conservation Service measured water levels in 239 wells completed in the alluvial aquifer and provided these data to the Arkansas Natural Resources Commission. In 2010, estimated water withdrawals from the alluvial aquifer in Arkansas totaled about 7,592 million gallons per day. Withdrawals more than doubled between 1985 and 2010, about a 115-percent increase.

The regional direction of groundwater flow is generally to the south and east except where flow is affected by groundwater withdrawals. East of Crowleys Ridge, water flows from north to south along Crowleys Ridge and northeast to southwest along the Mississippi River. West of Crowleys Ridge, water flows from northeast to southwest along Crowleys Ridge from Clay County to Craighead County. From Craighead County to Monroe County, a depression redirects groundwater flow from all directions. A depression in Arkansas, Lonoke, and Prairie Counties alters groundwater flow from all directions. South of the Arkansas River, the flow is towards the southeast, except near depressions in Lincoln and Desha Counties and Desha and Chicot Counties where flow is towards the depression. In 2012, the lowest waterlevel altitude was 73 feet (ft) in Arkansas County. The highest water-level altitude was $288 \mathrm{ft}$ in northeastern Clay County on the western side of Crowleys Ridge.

The 2012 potentiomentric-surface map shows eight depressions, two large depressions and six small depressions. One large depression begins in southeastern Arkansas County, at the Arkansas and Desha County line, extends north into Prairie County, west into Lonoke County, and east into the westernmost part of Monroe County. The area in Lonoke, Prairie, and White Counties in the northwestern half of the depression has a water-level altitude measurement of $90 \mathrm{ft}$ and has expanded into the northern third of Prairie County.

The 2012 potentiometric-surface map shows a general north-south depression with the southern end in central Monroe County through western Lee, St. Francis, Cross,
Poinsett, and Craighead Counties and eastern Woodruff and Jackson Counties. There are two deeper areas in this depression, one at the Monroe and Lee County line, with a low water-level altitude measurement of $123 \mathrm{ft}$, and the second in Poinsett County, with a low water-level altitude measurement of $113 \mathrm{ft}$. The six small depressions are located in northern Ashley County, in southern Desha and northern Chicot Counties, in eastern Lincoln and western Chicot Counties, at the Arkansas and Desha County line, in northern Phillips County, and in southeastern Greene County.

A map showing the difference in water levels was constructed using 541 differences in water levels measured during 2008 and 2012. The difference in measured water levels from 2008 to 2012 ranged from $-27.4 \mathrm{ft}$ to $18.7 \mathrm{ft}$, with a mean of $-1.0 \mathrm{ft}$. The largest decline of $-27.4 \mathrm{ft}$ occurred in Lonoke County, and the largest rise of $18.7 \mathrm{ft}$ occurred in Prairie County. Four areas were predominated by declines - west of Crowleys Ridge from Greene County south to Lee County, including Lawrence and southern Woodruff Counties; east of Crowleys Ridge from Clay County south to Poinsett County and Mississippi County; Lonoke and Jefferson Counties; and Ashley, Chicot, Desha, and Drew Counties. Three areas are predominated by rises in measured water levels-east of Crowleys Ridge in Crittenden, Cross, Lee, and St. Francis Counties; Jackson and northern Woodruff Counties; and Arkansas, Monroe, Phillips, Prairie, and White Counties.

Long-term water-level changes were evaluated using hydrographs from 319 wells in the alluvial aquifer for the period from 1988 to 2012. The annual rise or decline in water level for the entire study area was -0.45 feet per year (ft/yr) with a range from -2.08 to $0.84 \mathrm{ft} / \mathrm{yr}$. Arkansas County had two different rates of annual decline for the two hydrographs shown, about $0.97 \mathrm{ft} / \mathrm{yr}$ and about $0.26 \mathrm{ft} / \mathrm{yr}$.

In Craighead, Cross, Lee, Poinsett, and St. Francis Counties, water levels are declining at a greater rate in areas west of Crowleys Ridge than in areas east of Crowleys Ridge. Two hydrographs are shown in each of Craighead, Cross, Lee, Poinsett, and St. Francis Counties, one on the west side of Crowleys Ridge and one on the east side of Crowleys Ridge. The hydrographs west of Crowleys Ridge have annual waterlevel declines from -0.91 to $-1.24 \mathrm{ft} / \mathrm{yr}$. The hydrographs east of Crowleys Ridge have annual water-level declines from -0.07 to $-0.40 \mathrm{ft} / \mathrm{yr}$. The mean county annual water-level declines for these counties range from -0.55 to $-0.87 \mathrm{ft} / \mathrm{yr}$. 
Water samples were collected in the summer of 2012 from142 wells completed in the alluvial aquifer and measured onsite for specific conductance, temperature, and $\mathrm{pH}$. Samples were collected from 94 wells for dissolved chloride analysis. Specific conductance ranged from 91 microsiemens per centimeter at 25 degrees Celsius $\left(\mu \mathrm{S} / \mathrm{cm}\right.$ at $\left.25^{\circ} \mathrm{C}\right)$ in Drew County to $984 \mu \mathrm{S} / \mathrm{cm}$ at $25^{\circ} \mathrm{C}$ in Monroe County. The mean specific conductance was $547 \mu \mathrm{S} / \mathrm{cm}$ at $25^{\circ} \mathrm{C}$. Temperature ranged from 18.1 degrees Celsius $\left({ }^{\circ} \mathrm{C}\right)$ in Crittenden County to $22.4^{\circ} \mathrm{C}$ in Prairie County. The mean temperature was $22.1^{\circ} \mathrm{C}$. The $\mathrm{pH}$ ranged from 8.3 in Randolph County to 6.2 in Drew County and had a median of 7.3. Dissolved chloride concentrations ranged from 3.34 milligrams per liter $(\mathrm{mg} / \mathrm{L})$ in Randolph County to $182 \mathrm{mg} / \mathrm{L}$ in Lincoln County. The mean chloride concentration was $27.6 \mathrm{mg} / \mathrm{L}$.

\section{Introduction}

The Mississippi Alluvial Plain encompasses an area of approximately 32,000 square miles and includes parts of Arkansas and nearby States. Approximately 54 percent of the Mississippi Alluvial Plain covers the eastern one-third of Arkansas (fig. 1). The Mississippi River Valley alluvial aquifer (herein referred to as the alluvial aquifer) underlies the Mississippi Alluvial Plain in eastern Arkansas. Within Arkansas, the alluvial aquifer extends from the Missouri State line south to the Louisiana State line, and from the Mississippi River west to the Fall Line (the physiographic boundary between the Atlantic Plain and the Interior Highlands) and the Monticello Ridge (a topographic feature in southeastern Arkansas) (fig. 1).

During the spring of 2012, the U.S. Geological Survey (USGS), in cooperation with the Arkansas Natural Resources Commission (ANRC) and the Arkansas Geological Survey, measured water levels in 342 wells completed in the alluvial aquifer in eastern Arkansas. The ANRC measured water levels in 11 wells and the U.S. Department of AgricultureNatural Resources Conservation Service (NRCS) measured water levels in 239 wells completed in the alluvial aquifer and provided these data to the ANRC. The USGS incorporated those data into a database and developed a potentiometricsurface map of the alluvial aquifer for the spring of 2012 using all 592 water-level measurements made by the three agencies. Water samples collected in the summer of 2012 from 142 wells completed in the alluvial aquifer were measured onsite for specific conductance, temperature, and $\mathrm{pH}$. Dissolved chloride samples were collected from 94 wells and were analyzed by

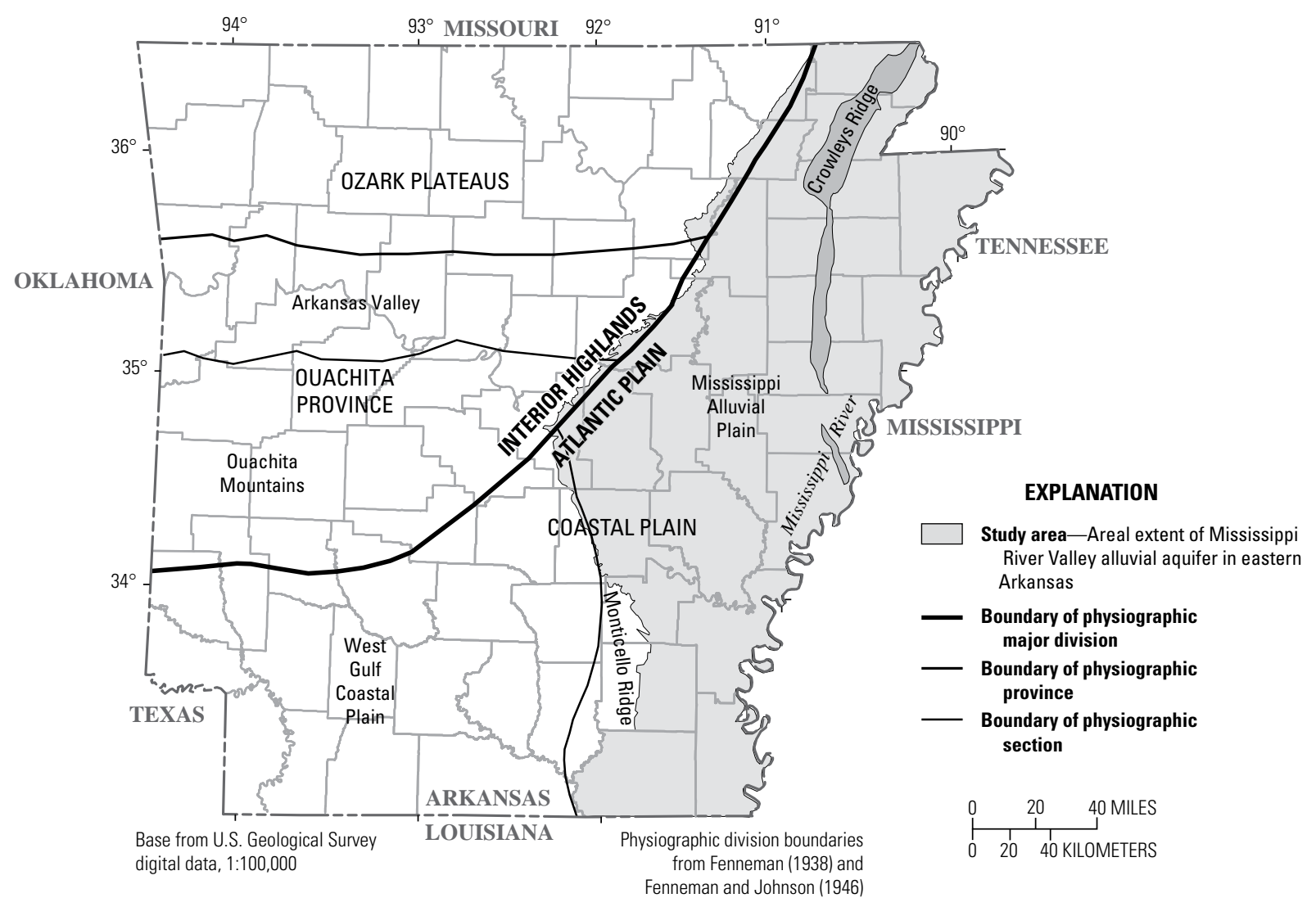

Figure 1. Location of study area. 
the USGS National Water Quality Laboratory. These analyses provided information for a database of selected water-quality data for the alluvial aquifer. Information in this report includes (1) groundwater levels for spring 2012, (2) a potentiometricsurface map, (3) a water-level difference map comparing water levels from 2008 to 2012, (4) selected water-level hydrographs, and (5) a groundwater water-quality data table for the summer of 2012.

\section{Water Use}

The alluvial aquifer is increasingly relied upon for agriculture and aquaculture water supply in eastern Arkansas. Estimated water withdrawals from the alluvial aquifer in Arkansas totaled about 7,592 million gallons per day (Mgal/d) in 2010 (Terrance W. Holland, U.S. Geological Survey, written commun., 2013) and about 1,063 Mgal/d in 1965 (fig. 2) (Halberg and Stephens, 1966), with an increase of about 614 percent. Withdrawals have more than doubled between 1985 and 2010, with an increase of about 115 percent. Starting in 1970 and continuing in 5-year intervals through 2005, estimated water withdrawals from the alluvial aquifer in Arkansas totaled about 1,287 Mgal/d, 2,211 Mgal/d,
3,697 Mgal/d, 3,534 Mgal/d, 4,360 Mgal/d, 5,056 Mgal/d, 6,585 Mgal/d, and 7,252 Mgal/d (Halberg, 1972, 1977;

Holland and Ludwig, 1981; Holland, 1987, 1993, 1999, 2004, 2007).

\section{Well-Numbering System}

The well-numbering system used in this report is based upon the Public Land Survey System used in Arkansas. The component parts of a well number are the township designation; the range designation; the section number; three-letter designation that indicates, respectively, the quarter section, the quarter-quarter section, and the quarter-quarterquarter section in which the well is located; and the sequence number of the well in the quarter-quarter-quarter section. The letters are assigned counterclockwise, beginning with " $\mathrm{A}$ " in the northeast quarter or quarter-quarter or quarter-quarterquarter section in which the well is located. For example, well 01S03W04BBD16 (fig. 3) is located in Township 1 South, Range 3 West, in the southeast quarter of the northwest quarter of the northwest quarter of section 4 . This well is the 16th well in this quarter-quarter-quarter section of section 4 from which data were collected.

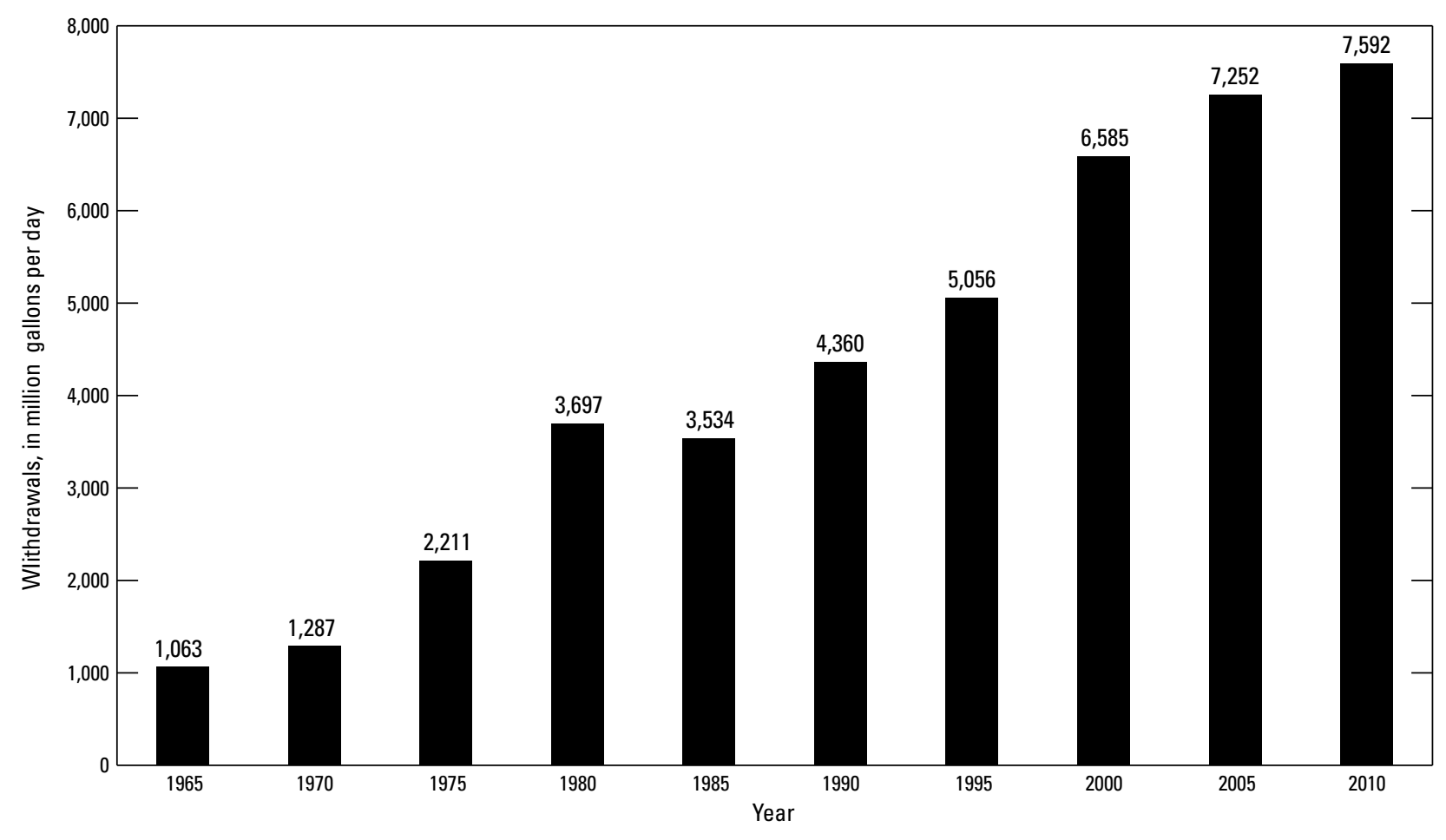

Data compiled from Halberg and Stephens (1966); Halberg (1972, 1977); Holland and Ludwig (1981); Holland (1987, 1993, 1999, 2004, 2007); and Terrance W. Holland (U.S. Geological Survey, written commun., 2013).

Figure 2. Water withdrawals from the Mississippi River Valley alluvial aquifer in Arkansas, 1965-2010. 


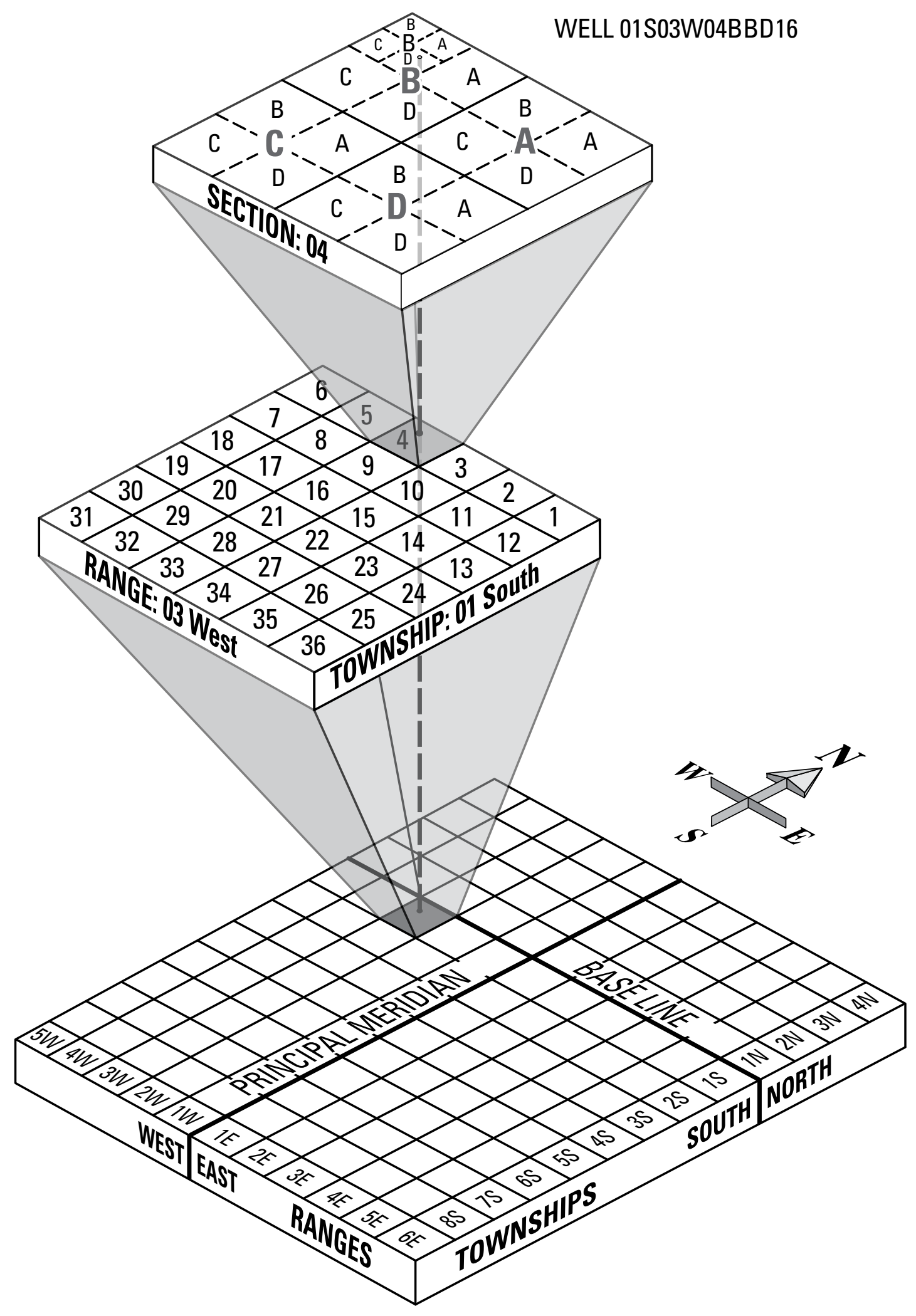

Figure 3. Well-numbering system. 


\section{Methods}

Water levels were measured from March to May 2012 by personnel from the USGS, ANRC, and NRCS from wells completed in the alluvial aquifer. Measurements were made using steel or electric tapes graduated in hundredths of a foot. Water levels were collected according to USGS technical procedures (Cunningham and Schalk, 2011). The steel and electric tapes were calibrated prior to collecting water-level measurements. Calibration was performed by comparing the steel or electric tapes to a standardized steel tape used only for calibration. Tape calibrations are performed annually.

Well locations were verified using Global Positioning System (GPS) receivers to acquire the horizontal-coordinate information, latitude and longitude, based on the North American Datum of 1983 (NAD 83). The latitude and longitude of the wells in Arkansas were recorded from a GPS receiver accurate to one-tenth of a second of latitude and longitude (approximately 10-20 feet [ft]). The latitude and longitude of each well were transferred to topographic maps, and the altitude of each well (National Geodetic Vertical Datum of 1929 [NGVD 29]) was determined from the topographic contours at the location on the map. Altitude is accurate to about 2.5 to $5 \mathrm{ft}$, or half the contour interval on the map. Wells with altitudes reported to the hundredths of a foot had levels measured to the well using surveying equipment.

Two methods are used for calculating the annual rise or decline of water levels. One method is to take the difference between the final and initial water levels and divide by the period of time. This method uses two measurements, and calculated values are dependent solely on the final and initial water levels. A second method uses the linear regression of water levels and time of measurement to calculate the annual rise or decline of water levels. Linear regression is more robust because it includes all the measurements to determine the trend line, resulting in a value that is dependent on all water levels during the period of record. The slope, $\beta$ (equation 1), of the line is the annual rise or decline of water levels. The intercept, $b_{0}$, is the projected water level in the year 1900, the origin for the graph. The predevelopment water level will not be discussed as this condition cannot be demonstrated. The equation of the regression line or line of best fit, $\mathrm{Y}=\mathrm{aX}+\mathrm{b}$, may be written as:

$$
h=\beta t+b_{0}
$$

where

$$
\begin{array}{cl}
\mathrm{h} & \text { is water-level altitude, in feet; } \\
\beta & \text { is the slope of the line, in feet per year; } \\
t & \text { is time, in years; and } \\
b_{0} & \text { is the y-intercept or water-level altitude at } \\
\text { time equal to 1900, in feet. }
\end{array}
$$

Five assumptions are associated with linear regression: (1) $\mathrm{Y}$ is linearly related to $\mathrm{X}$, (2) data used to fit the linear regression are representative of the data of interest, (3) variance of the residuals is constant and does not depend on X or on anything else, (4) the residuals are independent, and (5) the residuals are normally distributed. The assumption of a normal distribution is involved only when testing hypotheses, which requires the residuals from the regression equation to be normally distributed (Helsel and Hirsch, 1992).

The $\mathrm{R}^{2}$ term is the coefficient of determination, the correlation coefficient, or the fraction of variance explained by the regression. The $\mathrm{R}^{2}$ value gives the proportions of the total variability that can be accounted by the independent variable (Helsel and Hirsch, 1992). Values of $\mathrm{R}^{2}$ can range from 0.00 to 1.00. A large value of $\mathrm{R}^{2}$ can indicate a linear change in water level. A low value of $\mathrm{R}^{2}$ can indicate sporadic change in water level.

Water-quality samples were collected for specific conductance, $\mathrm{pH}$, and temperature using the procedures described in the National Field Manual for the Collection of Water-Quality Data (U.S. Geological Survey, variously dated). Samples also were collected for dissolved chloride analysis at the USGS National Water Quality Laboratory (Fishman and Friedman, 1989). Wells were purged a minimum of three-casing volumes at a pumping rate that ranged from 100 to 500 gallons per minute. The purge process is important to obtain an accurate water-quality sample that is representative of the aquifer conditions without the effects of the borehole environment. Casing volumes for the wells were calculated from the well-casing diameter, depth to water, and well depth. The cross-sectional area of the casing was calculated from the casing diameter, and the height of the water column was determined by subtracting the depth to water from the well depth. The area and the height of the water column were multiplied for a casing volume in cubic feet, then converted to gallons. The calculated purge volume at each well was then divided by the pumping rate to determine the minimum pumping time for purging.

During the purge process, specific conductance, $\mathrm{pH}$, and temperature were measured from selected wells using specific-conductance and $\mathrm{pH}$ meters with temperature compensation until measurements stabilized (Fishman and Friedman, 1989). A field meter was calibrated twice daily by comparing the measurements of two specific conductance standards and two $\mathrm{pH}$ calibration standards. Specific conductance is a measure of the electrical conductance of a solution normalized to 25 degress Celsius $\left({ }^{\circ} \mathrm{C}\right)$, an indicator of the presence of charged ionic species or dissolved solids. As the ion concentration increases in groundwater, the conductivity of the groundwater increases. The $\mathrm{pH}$ is a measure of the acidity of the water, an indicator of the hydrogen ion concentration and activity. 
Water Levels and Water Quality in the Mississippi River Valley Alluvial Aquifer in Eastern Arkansas, 2012

\section{Aquifer Description}

The alluvial aquifer comprises alluvial and terrace deposits of Quaternary age (Ackerman, 1996). Lithologically, the Quaternary alluvial and terrace deposits are similar, consisting of unconsolidated sediments that grade from gravel and coarse sand in the lower sections to silt and clay in the upper sections (Boswell and others, 1968). The coarse sediments contained in the lower sections of the alluvial and terrace deposits are capable of sustaining high-yielding wells (Ackerman, 1996). Finer sediments in the upper sections of the alluvial and terrace deposits form a confining unit above much of the aquifer. This confining unit is thin or has been completely removed by erosion in some areas, especially near large rivers within the study area (Gonthier and Mahon, 1993). Channel fill, point bar, and backswamp deposits associated with present or former channels of large rivers have produced abrupt changes in lithology and result in large spatial variations in the hydraulic properties of the aquifer (Joseph, 1999).

Sedimentary rocks and unconsolidated sediments of Tertiary age or older underlie the alluvial aquifer and have been modified by geologic processes into an undulating surface (Mahon and Poynter, 1993). In most areas, these rocks and sediments are less permeable than the overlying alluvial and terrace deposits of Quaternary age and form the confining unit below the alluvial aquifer (Boswell and others, 1968).

In the northern half of the study area, the alluvial and terrace deposits of Quaternary age are separated by Crowleys Ridge (fig. 1), an erosional remnant of deposits of Tertiary age trending north-south from the Missouri-Arkansas border. Crowleys Ridge is a prominent topographic feature on the otherwise low-relief surface of the Mississippi Alluvial Plain and forms a physical barrier to groundwater flow in the alluvial aquifer.

\section{Water Levels}

Water-level measurements in wells completed in the alluvial aquifer (app. 1) were used to produce a regional potentiometric-surface map (pl. 1). The water-level altitudes for the potentiometric-surface map were calculated by subtracting the depth-to-water measurement from the landsurface altitude, then rounding to the nearest foot. All water levels on the potentiometric-surface map (pl. 1), the longterm hydrographs, and appendix 1 are in feet of altitude, referenced to NGVD 29. A difference in water-level map from 2008 to 2012 (pl. 2) was produced by subtracting water-level measurements in 2012 from measurements in 2008. Data from wells that have water-level measurements with a minimum 25-year period of record were used to produce hydrographs. The water-level changes shown in the hydrographs indicate long-term changes in hydrologic conditions. Long-term waterlevel changes shown by many of the hydrographs reflect the development of depressions in the potentiometric surface.

\section{Potentiometric-Surface Map}

The potentiometric-surface map (pl. 1) shows the altitude at which water would have stood in tightly cased wells completed in the alluvial aquifer. The map on plate 1 is based on water-level measurements (342 by USGS, 11 by ANRC, and 239 by NRCS) made in 592 wells during the spring of 2012 (app. 1). The potentiometric surface was mapped using the altitude of the water levels measured in the wells and is represented on the map by contours that connect points of equal altitude. The general direction of groundwater flow is perpendicular to the contours in the direction of decreasing potentiometric-surface altitude. In 2012, the lowest water-level altitude was $73 \mathrm{ft}$ in Arkansas County. The highest water-level altitude was $288 \mathrm{ft}$ in northeastern Clay County on the western side of Crowleys Ridge.

The regional direction of groundwater flow is generally to the south and east except where flow is affected by groundwater withdrawals. The groundwater flow direction is affected over substantial areas by depressions (pl. 1). East of Crowleys Ridge, water flows from north to south along Crowleys Ridge and northeast to southwest along the Mississippi River. West of Crowleys Ridge, water flows from northeast to southwest along Crowleys Ridge from Clay County to Craighead County. From Craighead County to Monroe County, a depression alters groundwater flow from all directions. The depression in Arkansas, Lonoke, and Prairie Counties also alters groundwater flow from all directions. The flow along large sections of the Arkansas, Mississippi, and White Rivers is away from the rivers. South of the Arkansas River, the flow is towards the southeast, except near the depressions in Lincoln and Desha Counties and Desha and Chicot Counties where flow is towards the depressions.

Previous reports described three large depressions in the alluvial aquifer potentiometric surface (Stanton and others, 1998; Joseph, 1999; Schrader, 2001; Reed, 2004; Schrader, 2006, 2008, 2010). A large, elongated area of depression extends across Arkansas, Lonoke, Prairie, and White Counties. Two shallow depressions in Lee, Monroe, St. Francis, and Woodruff Counties and in Craighead, Cross, and Poinsett Counties have now merged into a single depression.

The 2012 potentiomentric-surface map shows eight depressions, two large depressions and six small depressions. One large depression begins in southeastern Arkansas County, at the Arkansas and Desha County line, and extends north into Prairie County, west into Lonoke County, and east into the westernmost part of Monroe County. The area in Arkansas County within the southeastern half of the depression has not expanded horizontally during recent years, although the center of the depression has deepened. The lowest water-level altitude measurement is $73 \mathrm{ft}$. The Arkansas and White Rivers that bound Arkansas County on the southwestern and eastern county lines are hydrologically connected to the alluvial aquifer and provide recharge. The area in Lonoke, Prairie, and White Counties in the northwestern half of the depression has a low water-level altitude measurement of $90 \mathrm{ft}$ and has expanded into the northern third of Prairie County. 
Along the western side of Crowleys Ridge, two previously documented areas of depression expanded and merged into a single depression by 2002 (Reed, 2004). The 2012 potentiometric-surface map shows a general north-south depression with the southern end in central Monroe County extending through western Lee, St. Francis, Cross, Poinsett, and Craighead Counties and eastern Woodruff and Jackson Counties. Two deeper areas occur in this depression, one at the Monroe and Lee County line, with a low water-level altitude measurement of $123 \mathrm{ft}$, and the second in Poinsett County, with a low water-level altitude measurement of $113 \mathrm{ft}$.

Six small depressions are shown in the 2012 potentiometric-surface map. Beginning at the south end of the map, there is a depression in northern Ashley County, with a low water-level altitude measurement of $96 \mathrm{ft}$. The depression in northern Chicot and southern Desha Counties was first evident in the 1998 potentiometric surface (Joseph, 1999) and has a low water-level altitude measurement of $86 \mathrm{ft}$. The depression in eastern Lincoln and western Desha Counties was first evident in the 2002 potentiometric surface (Schrader, 2006) and has a low water-level altitude measurement of $110 \mathrm{ft}$. The depression at the Desha and Arkansas County line was first evident in the 2006 potentiometric surface (Schrader, 2008) and has a low water-level altitude measurement of $113 \mathrm{ft}$. The depression in northern Phillips County is shown for the first time in the 2012 potentiometric surface and has a low water-level altitude measurement of $149 \mathrm{ft}$. The depression in southeastern Greene County was first evident in the 1998 potentiometric surface (Joseph, 1999) and has a low water-level altitude measurement of $214 \mathrm{ft}$. Continued monitoring of the potentiometric surface will determine if these small depressions are the result of short-term variations or long-term changes in the hydrologic conditions in the alluvial aquifer.

\section{Water-Level Difference from 2008 to 2012}

A map showing the difference in water level (pl. 2) was constructed using 541 differences in water levels measured during 2012 (app. 2) and 2008 (Schrader, 2010). Differences in water level were calculated by subtracting the 2012 depth-to-water measurement from the 2008 depth-to-water measurement. Positive values indicate a rise and negative values indicate a decline in water level. Rises in water level are indicated on plate 2 with blue triangles pointing upward; declines in water level are indicated with red triangles pointing downward. The triangle size is scaled to the value of rise or decline.

The difference in measured water levels from 2008 to 2012 ranged from $-27.4 \mathrm{ft}$ to $18.7 \mathrm{ft}$, with a mean of $-1.0 \mathrm{ft}$. The largest decline of $-27.4 \mathrm{ft}$ occurred in Lonoke County and the largest rise of $18.7 \mathrm{ft}$ occurred in Prairie County. Out of the 541 differences on plate 2, 335 were declines (61.9 percent), 16 were no difference (values of $0.0 \mathrm{ft}$; 3.0 percent), and 190 were rises ( 35.1 percent). Four areas are predominated by declines - west of Crowleys Ridge from Greene County south to Lee County, including eastern Lawrence and southern Woodruff Counties; east of Crowleys Ridge from Clay County south to Mississippi and Poinsett Counties; Lonoke and Jefferson Counties; and Desha, Drew, Chicot, and Ashley Counties. Three areas are predominated by rises in measured water levels_-Jackson and northern Woodruff Counties; east of Crowleys Ridge in Crittenden, Cross, St. Francis, and Lee Counties; and White, Prairie, Monroe, Arkansas, and Phillips Counties.

\section{Long-Term Hydrographs}

Long-term water-level changes were evaluated using hydrographs from 319 wells in the alluvial aquifer for the period from 1988 to 2012. The minimum 25-year period is used to show long-term trends not dominated by shortterm variations in climate and localized pumping rates on water levels in a single well. Linear regression was used to calculate the trend in water-level change for each well for this period. The slope of the trend line represents the annual rise or decline in water level during the 25-year period. Negative values denote a decline in water level and positive values indicate a rise. The hydrographs were grouped by county. The number of wells, the range of values for the annual rise or decline in water level, the mean, the median, and the correlation coefficient $\left(\mathrm{R}^{2}\right)$ for each county are listed in table 1 . The mean county annual rises and declines in water level for the entire study area were -0.45 feet per year (ft/yr) with a range from -2.08 to $0.84 \mathrm{ft} / \mathrm{yr}$. Selected hydrographs are shown in figure 4 (wells A-FF, pl. 1).

Long-term water-level changes varied substantially across the study area. The mean rise or decline for Independence and White Counties have an annual rise from 1988 to 2012. The rise in Independence County was determined from the data of one well. Mean county annual declines between $-0.50 \mathrm{ft} / \mathrm{yr}$ and $0.00 \mathrm{ft} / \mathrm{yr}$ occurred in Arkansas, Ashley, Chicot, Clay, Crittenden, Drew, Greene, Jefferson, Mississippi, Monroe, Phillips, Prairie, Pulaski, Randolph, and Woodruff Counties. The mean county annual declines between $-1.00 \mathrm{ft} / \mathrm{yr}$ and $-0.50 \mathrm{ft} / \mathrm{yr}$ occurred in Craighead, Cross, Desha, Jackson, Lee, Lincoln, Lonoke, Poinsett, and St. Francis Counties.

The analysis of long-term water-level changes (19882012) in Arkansas, Lonoke, and Prairie Counties shows the elongation of the depression in these three counties. Arkansas County has two different rates of annual decline for the two hydrographs shown. Well 04S03W32BCB1 (fig. 4A, pl. 1) shows an annual water-level decline of about $0.97 \mathrm{ft} / \mathrm{yr}$ since 1988. Well 04S03W32BCB1 is located near the center of the depression in Arkansas County and generally shows a water-level decline during the 76-year period of record. Well 07S04W01DDD1 (fig. 4B, pl. 1) has an annual water-level rise of about $0.26 \mathrm{ft} / \mathrm{yr}$ since 1988. Well 07S04W01DDD1 is located near the Arkansas River and shows a relatively stable water level to about 1990 with larger fluctuations from 1990 to present. The water level in the Arkansas River 
Table 1. Range, mean, median, and correlation coefficient, $R^{2}$, of annual rise-decline in water level by county for wells in the Mississippi River Valley alluvial aquifer, 1988-2012.

[Annual rise or decline in water level for each well is calculated using linear regression; negative value indicates decline; positive value indicates rise]

\begin{tabular}{|c|c|c|c|c|c|}
\hline County & $\begin{array}{l}\text { Number } \\
\text { of wells }\end{array}$ & $\begin{array}{c}\text { Range of annual } \\
\text { rise-decline } \\
\text { in water level } \\
\text { (feet/year) }\end{array}$ & $\begin{array}{c}\text { Mean annual } \\
\text { rise-decline } \\
\text { in water level } \\
\text { (feet/year) }\end{array}$ & $\begin{array}{c}\text { Median annual } \\
\text { rise-decline } \\
\text { in water level } \\
\text { (feet/year) }\end{array}$ & $\begin{array}{c}\text { Range of } \\
\mathbf{R}^{2} \text { values } \\
\text { for trend line }\end{array}$ \\
\hline Arkansas & 25 & -0.99 to 0.84 & -0.14 & -0.18 & 0.15 to 0.83 \\
\hline Ashley & 13 & -0.77 to 0.11 & -0.31 & -0.33 & 0.17 to 0.87 \\
\hline Chicot & 8 & -1.10 to 0.26 & -0.49 & -0.42 & 0.24 to 0.94 \\
\hline Clay & 19 & -1.06 to -0.01 & -0.32 & -0.18 & 0.16 to 0.96 \\
\hline Craighead & 16 & -1.50 to 0.04 & -0.55 & -0.42 & 0.25 to 0.97 \\
\hline Crittenden & 7 & -0.69 to -0.07 & -0.36 & -0.37 & 0.19 to 0.94 \\
\hline Cross & 23 & -1.20 to -0.18 & -0.87 & -0.95 & 0.33 to 0.99 \\
\hline Desha & 16 & -1.13 to -0.15 & -0.67 & -0.71 & 0.17 to 0.92 \\
\hline Drew & 7 & -0.55 to -0.22 & -0.40 & -0.37 & 0.19 to 0.84 \\
\hline Greene & 8 & -0.77 to 0.04 & -0.25 & -0.22 & 0.08 to 0.93 \\
\hline Independence & 1 & 0.15 to 0.15 & 0.15 & 0.15 & 0.23 to 0.23 \\
\hline Jackson & 6 & -0.80 to -0.26 & -0.65 & -0.75 & 0.68 to 0.97 \\
\hline Jefferson & 8 & -1.21 to -0.15 & -0.44 & -0.38 & 0.16 to 0.91 \\
\hline Lee & 25 & -1.53 to 0.11 & -0.64 & -0.62 & 0.20 to 0.94 \\
\hline Lincoln & 10 & -1.21 to -0.26 & -0.71 & -0.69 & 0.23 to 0.84 \\
\hline Lonoke & 14 & -1.50 to -0.01 & -0.73 & -0.71 & 0.22 to 0.98 \\
\hline Mississippi & 8 & -0.33 to 0.04 & -0.08 & -0.07 & 0.16 to 0.60 \\
\hline Monroe & 19 & -0.84 to 0.26 & -0.27 & -0.26 & 0.18 to 0.95 \\
\hline Phillips & 17 & -0.69 to 0.02 & -0.22 & -0.22 & 0.11 to 0.73 \\
\hline Poinsett & 25 & -2.08 to 0.07 & -0.82 & -0.91 & 0.17 to 0.98 \\
\hline Prairie & 8 & -0.58 to 0.15 & -0.21 & -0.18 & 0.13 to 0.95 \\
\hline Pulaski & 1 & -0.22 to -0.22 & -0.22 & -0.22 & 0.46 to 0.46 \\
\hline Randolph & 4 & -0.51 to -0.04 & -0.28 & -0.29 & 0.18 to 0.72 \\
\hline St. Francis & 7 & -0.91 to -0.18 & -0.66 & -0.66 & 0.35 to 0.97 \\
\hline White & 8 & -0.58 to 0.51 & 0.12 & 0.18 & 0.19 to 0.65 \\
\hline Woodruff & 16 & -0.99 to 0.66 & -0.18 & -0.09 & 0.12 to 0.96 \\
\hline
\end{tabular}

is maintained by a lock and dam system and can be a source of water for the alluvial aquifer in southern and western Arkansas County. Well 04N05W07CDC1 (fig. 4Z, pl. 1) is located in the central part of Prairie County and has an annual decline of about $0.51 \mathrm{ft} / \mathrm{yr}$ since 1988. Well 02S07W10CCB1 (fig. 4T, pl. 1), near the western edge of the depression in Lonoke County, shows an annual water-level decline of about $0.69 \mathrm{ft} / \mathrm{yr}$ since 1988 and shows a nearly continuous waterlevel decline during the 55 years of record. These rates of water-level change indicate that this depression has expanded in an elongated direction north and west into Lonoke and Prairie Counties from 1988 to 2012. Water-level declines in neighboring counties are further evidence of the expansion of the depression centered in Arkansas, Lonoke, and Prairie Counties. In Jefferson County, well 03S08W24BBC1 (fig. 4P, pl. 1) has an annual water-level decline of about $0.58 \mathrm{ft} / \mathrm{yr}$ during the period from 1988 to 2012. Long-term declines in this outlying well indicate that the depression is expanding.

In Craighead, Cross, Lee, Poinsett, and St. Francis Counties water levels are declining at a greater rate west of Crowleys Ridge than east of Crowleys Ridge. Two hydrographs are shown in each of Craighead, Cross, Lee, Poinsett, and St. Francis Counties, one on the west side of Crowleys Ridge and one on the east side of Crowleys Ridge. The hydrographs west of Crowleys Ridge have annual waterlevel declines from - 0.91 to $-1.24 \mathrm{ft} / \mathrm{yr}$ during the period from 1988 to 2012. The hydrographs east of Crowleys Ridge have annual water-level declines from -0.07 to $-0.40 \mathrm{ft} / \mathrm{yr}$ during the period from 1988 to 2012. The mean county annual declines for these counties are from -0.55 to $-0.87 \mathrm{ft} / \mathrm{yr}$ during the period from 1988 to 2012. The annual declines for these counties indicate the two different conditions in each county. 

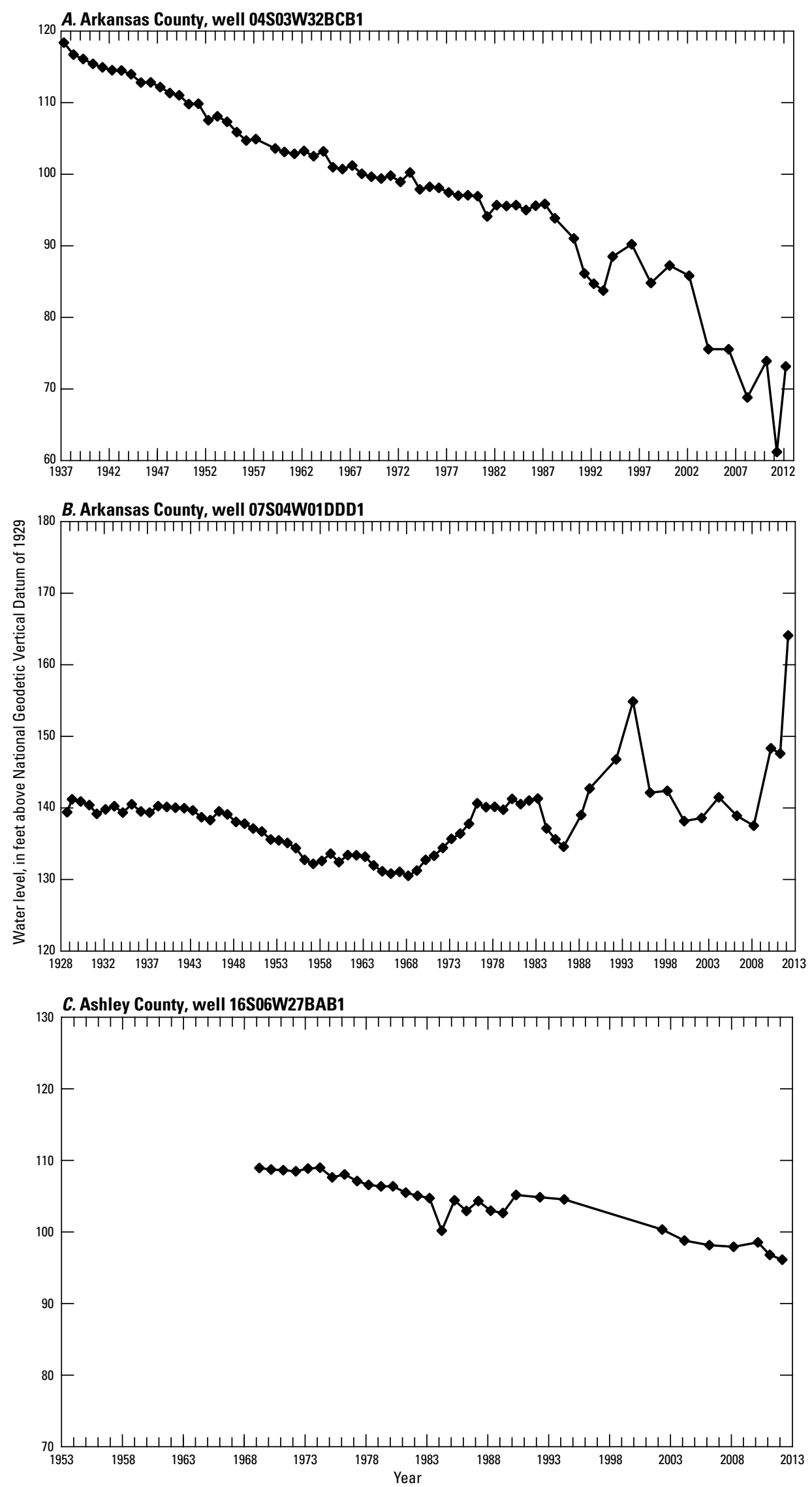

Figure 4. Water-level hydrographs for selected wells completed in the Mississippi River Valley alluvial aquifer in Arkansas. 

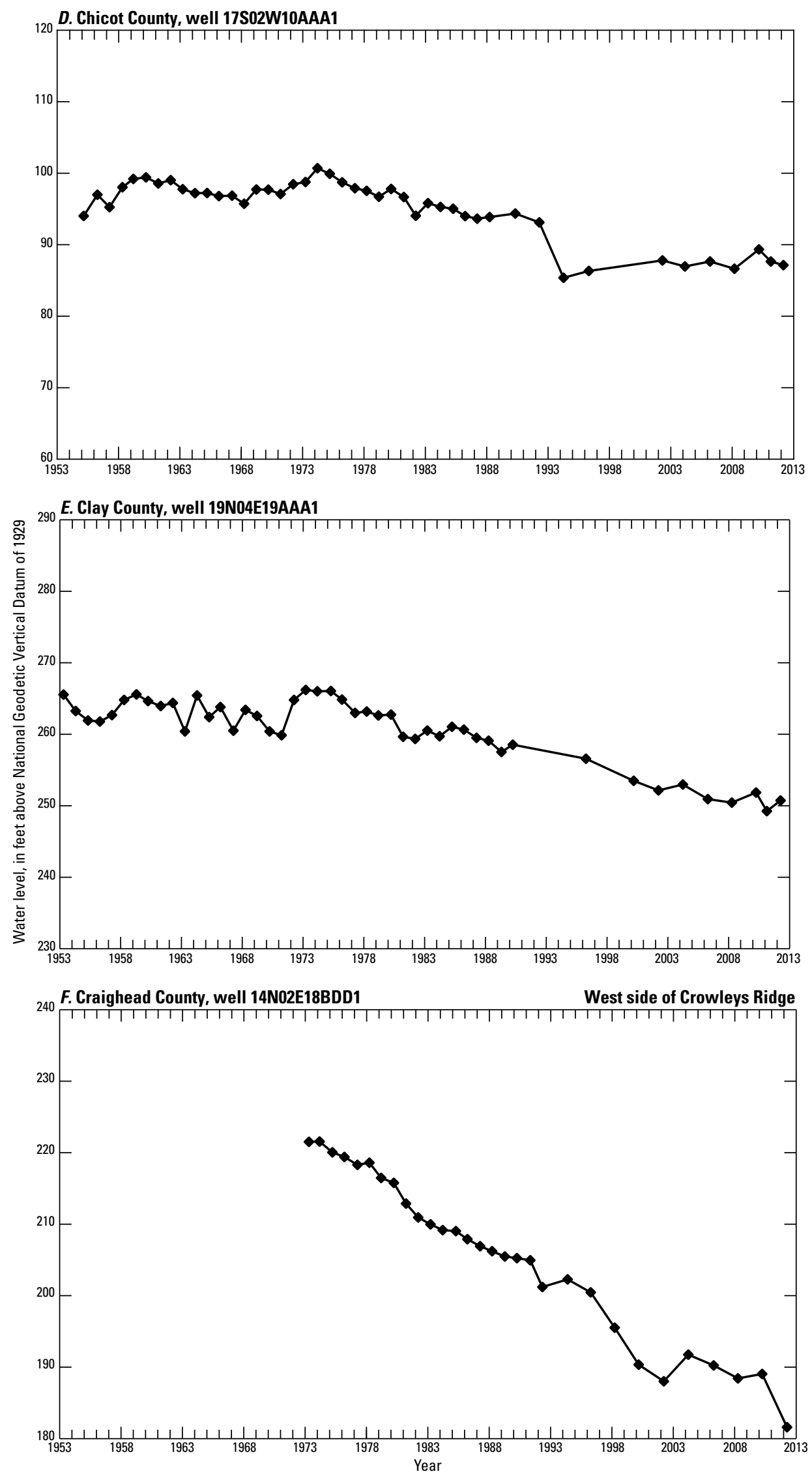

Figure 4. Water-level hydrographs for selected wells completed in the Mississippi River Valley alluvial aquifer in Arkansas.-Continued 

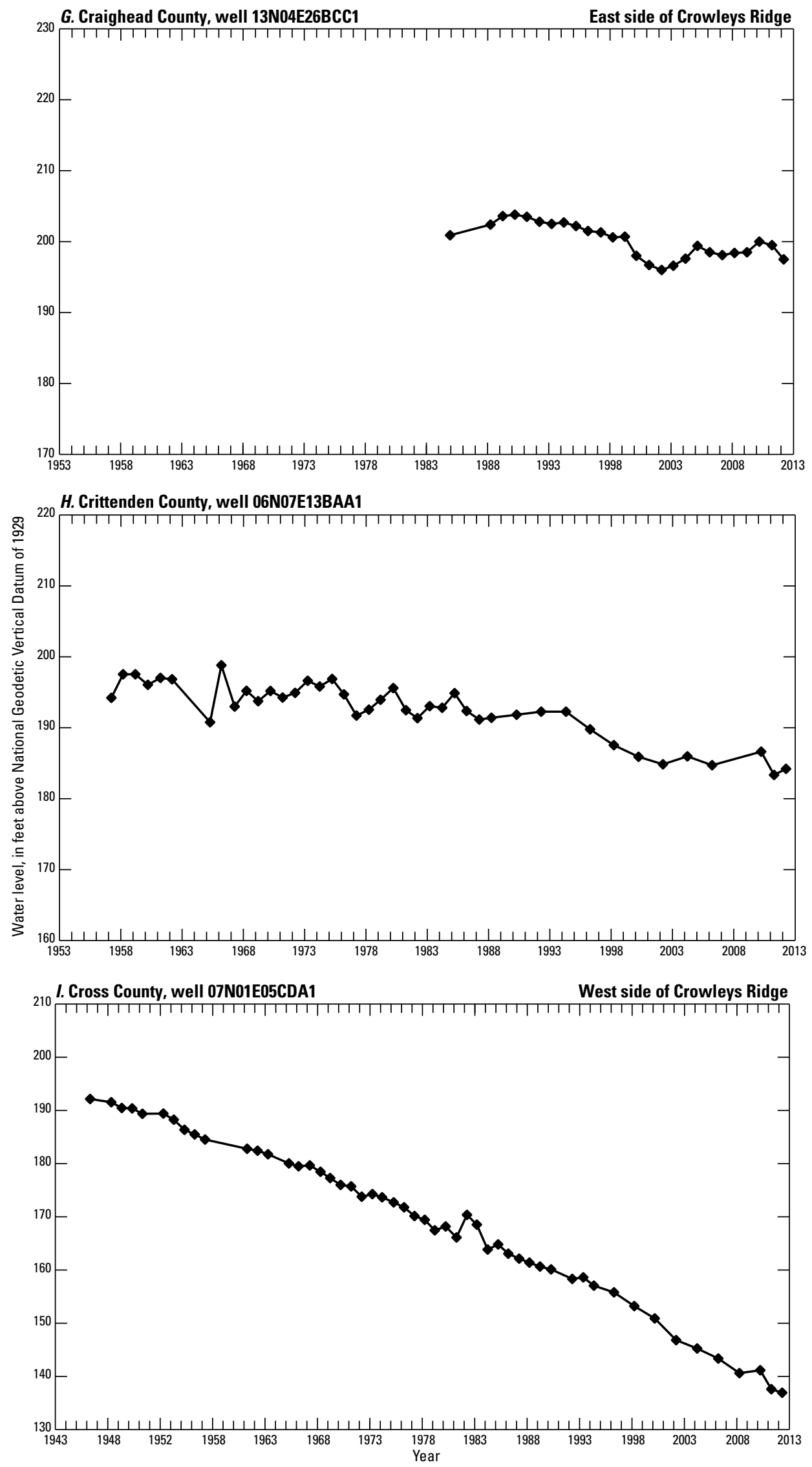

Figure 4. Water-level hydrographs for selected wells completed in the Mississippi River Valley alluvial aquifer in Arkansas.-Continued 

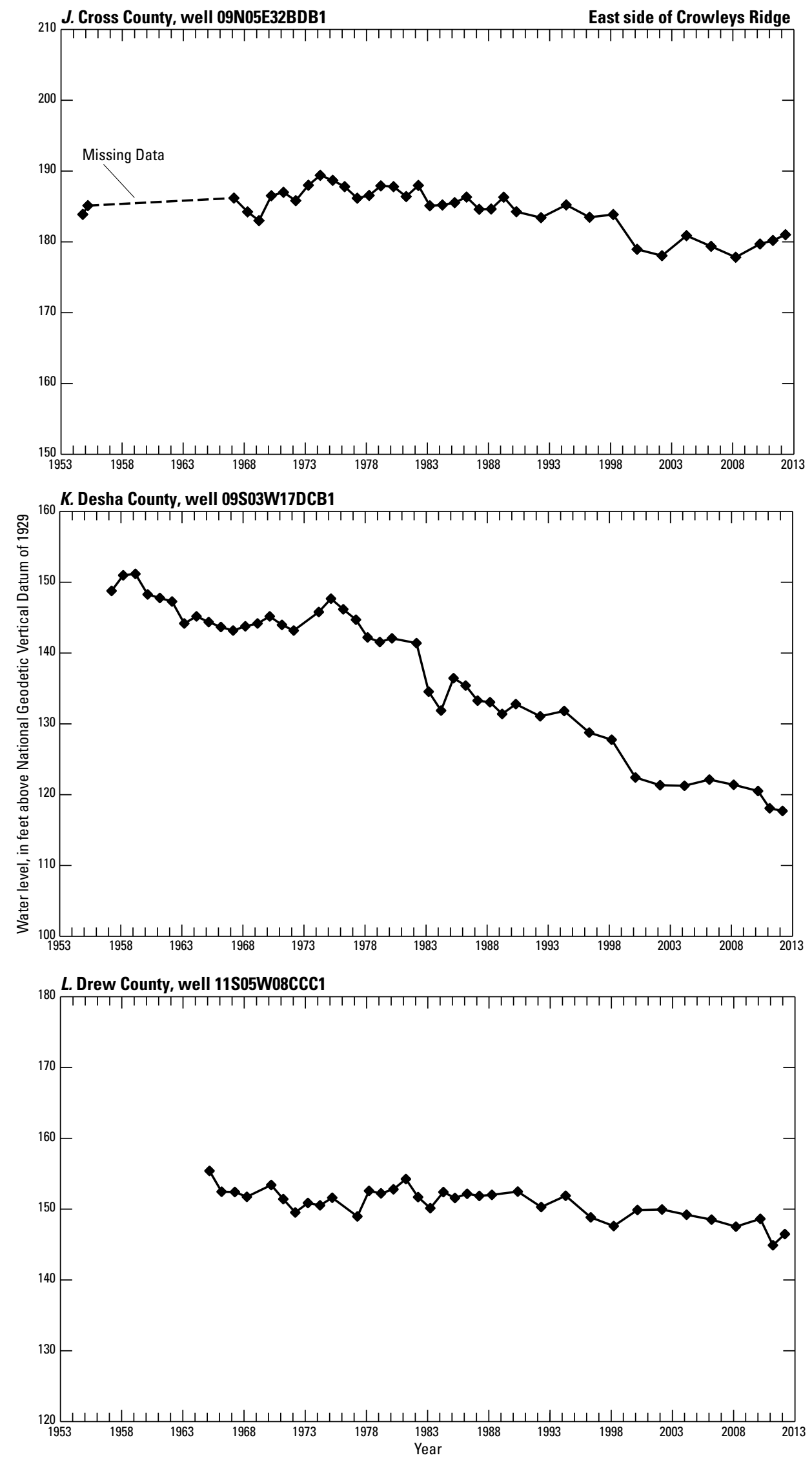

Figure 4. Water-level hydrographs for selected wells completed in the Mississippi River Valley alluvial aquifer in Arkansas.-Continued 

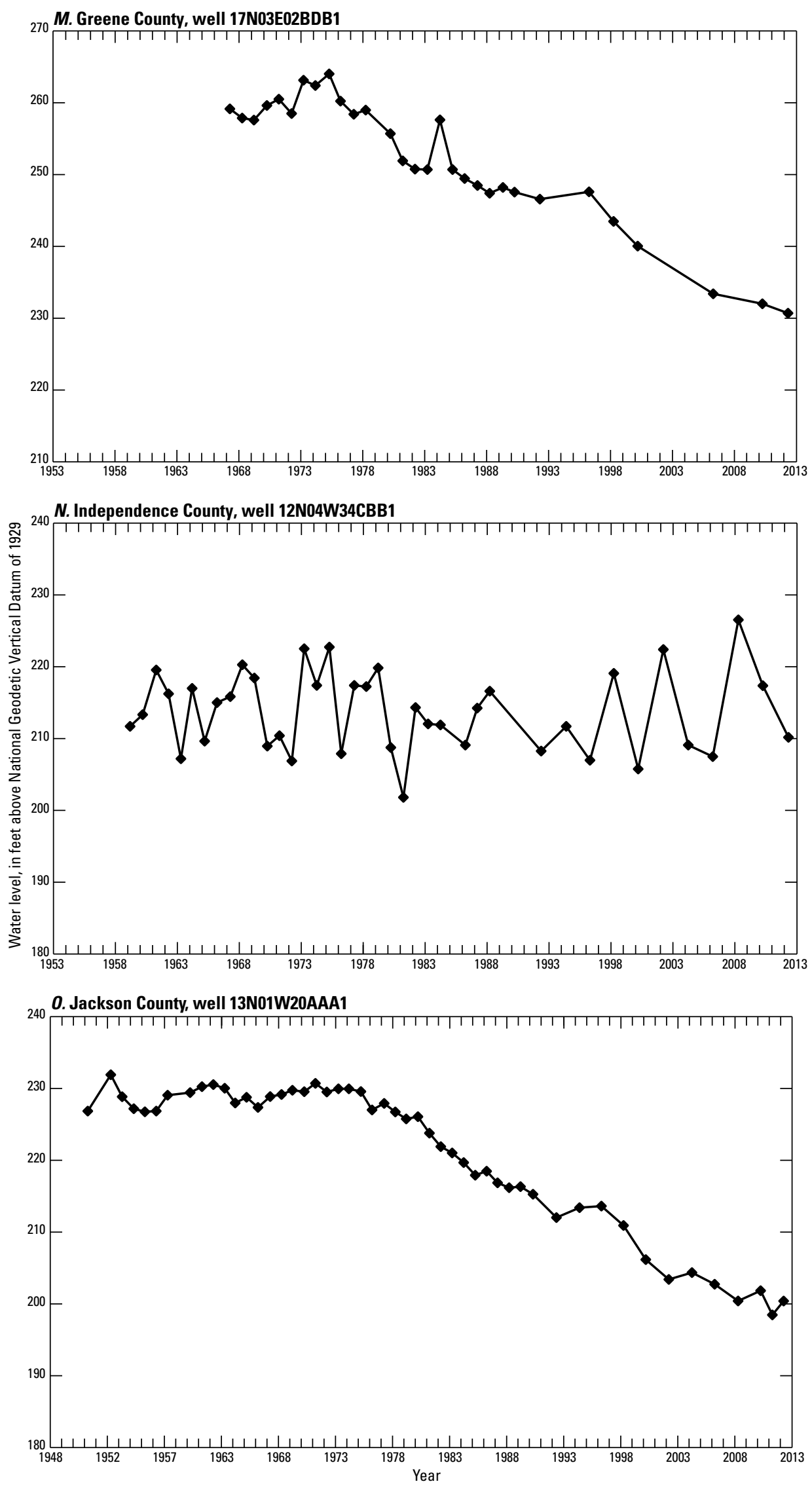

Figure 4. Water-level hydrographs for selected wells completed in the Mississippi River Valley alluvial aquifer in Arkansas.-Continued 

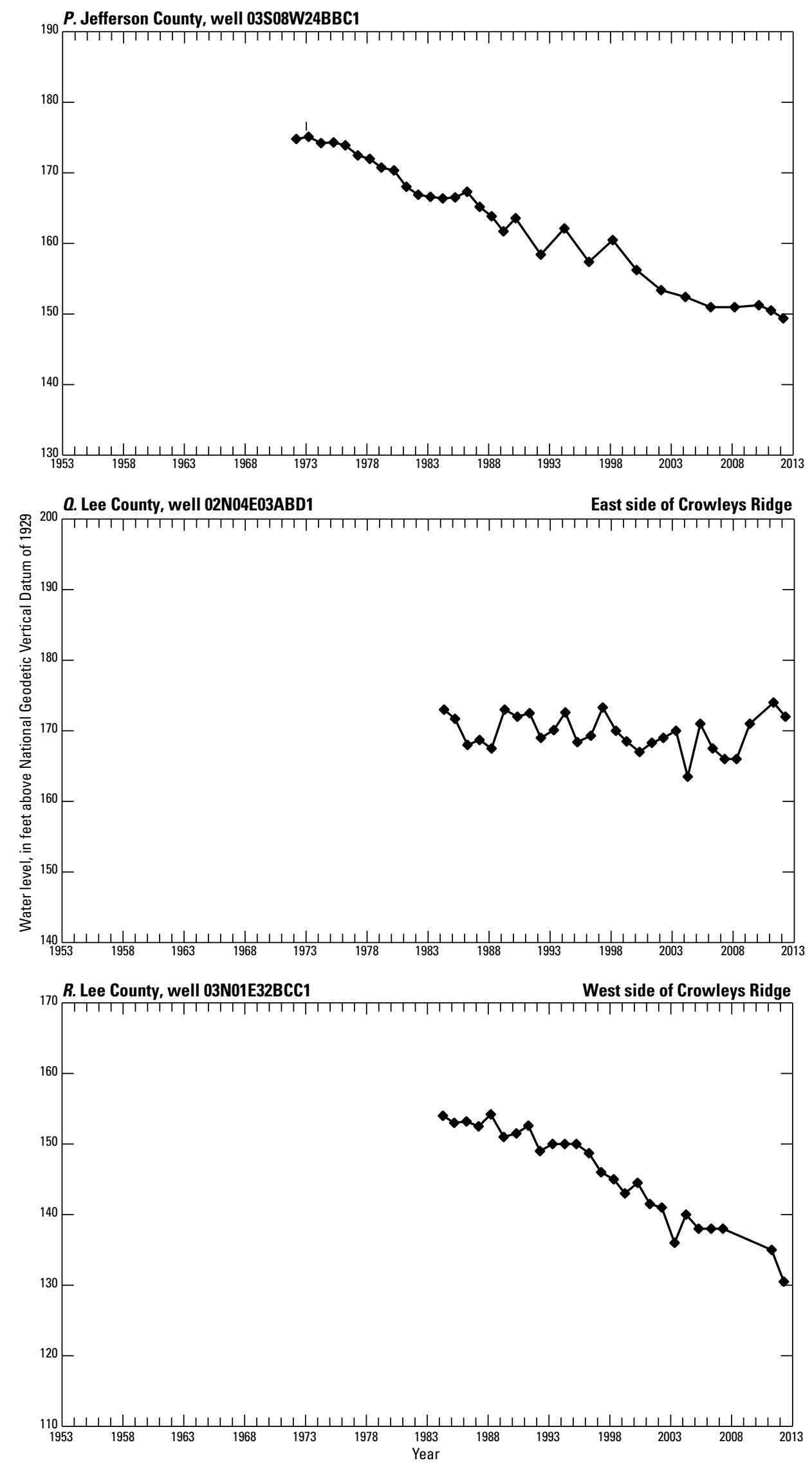

Figure 4. Water-level hydrographs for selected wells completed in the Mississippi River Valley alluvial aquifer in Arkansas.-Continued 

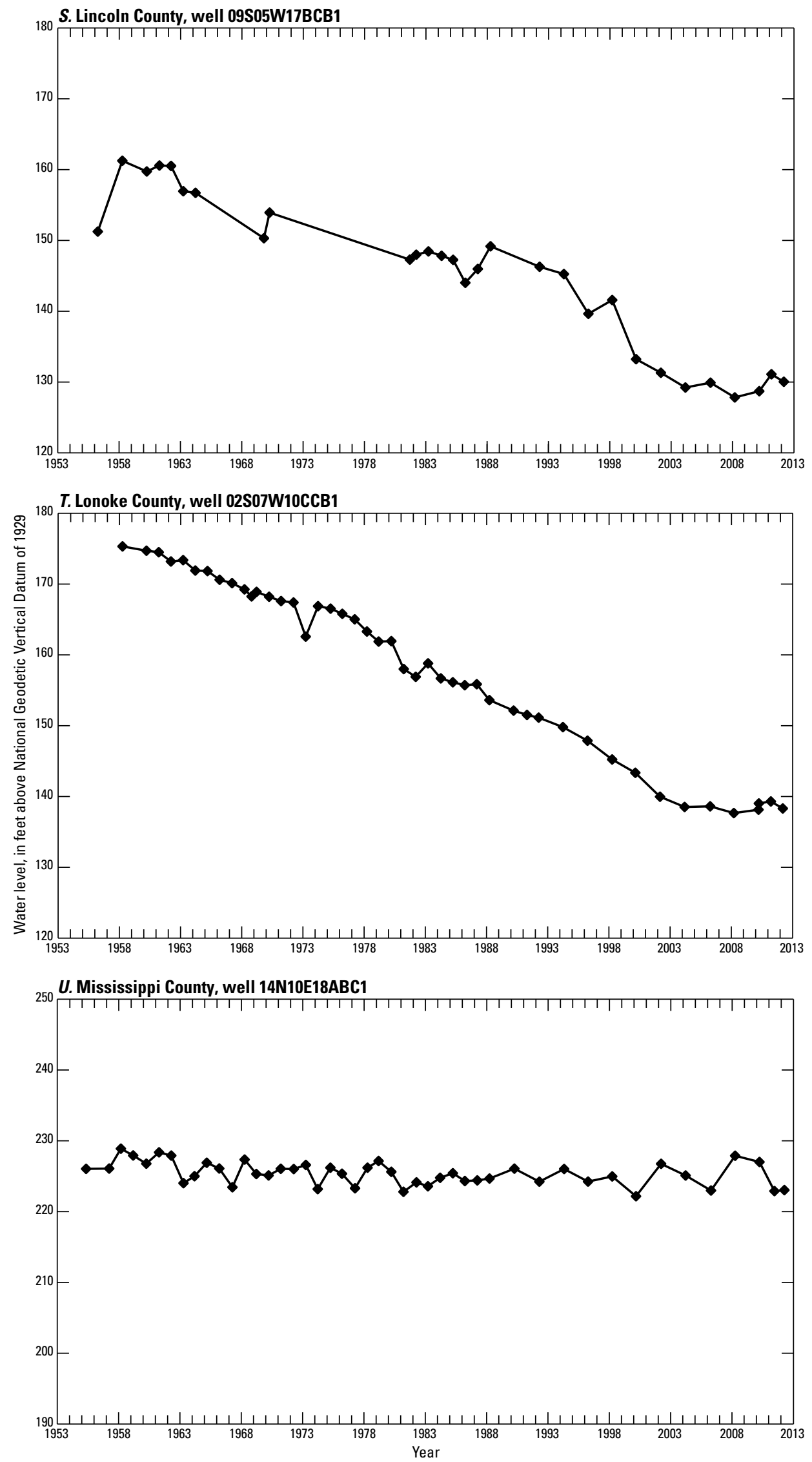

Figure 4. Water-level hydrographs for selected wells completed in the Mississippi River Valley alluvial aquifer in Arkansas.-Continued 

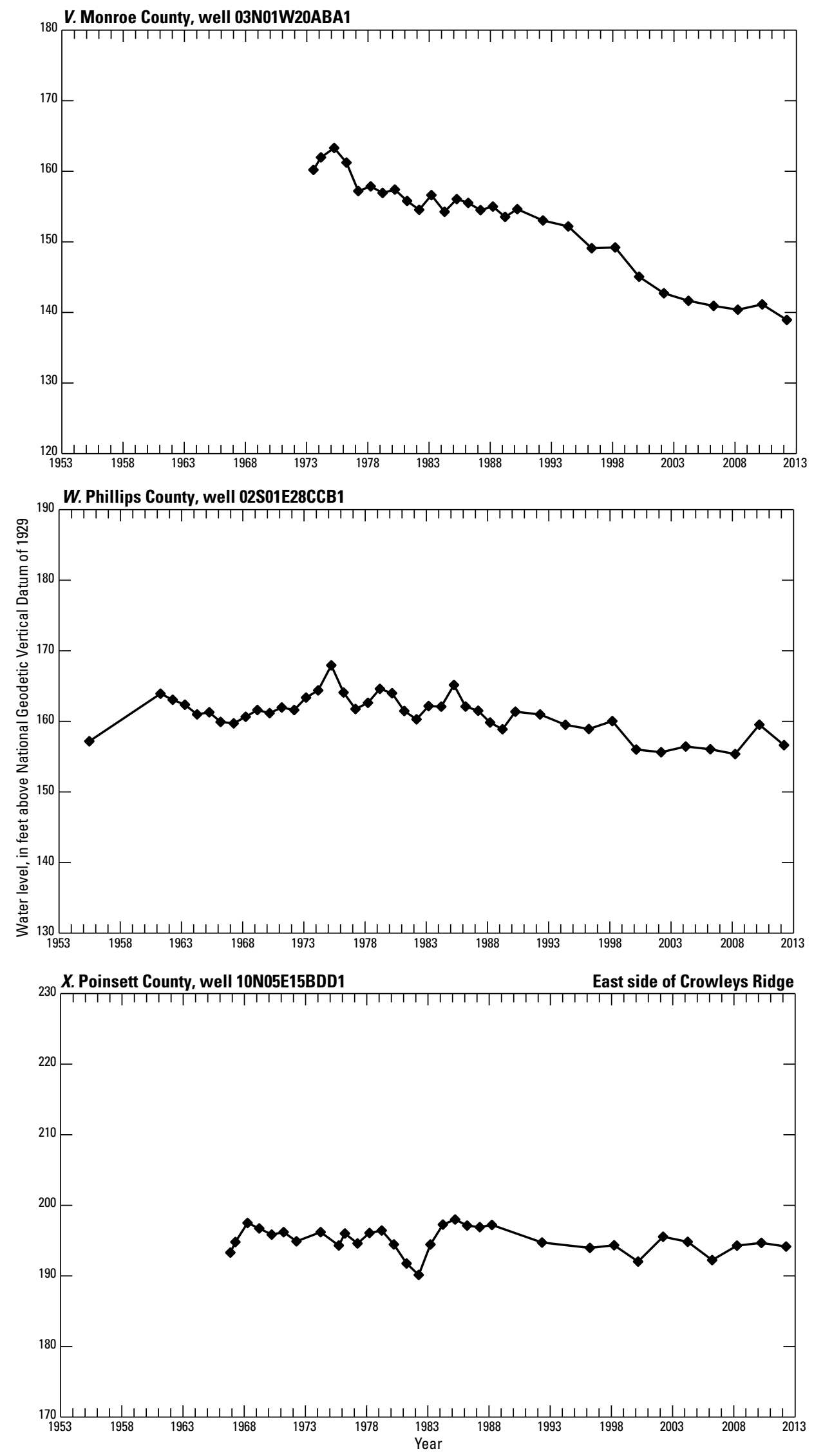

Figure 4. Water-level hydrographs for selected wells completed in the Mississippi River Valley alluvial aquifer in Arkansas.-Continued 

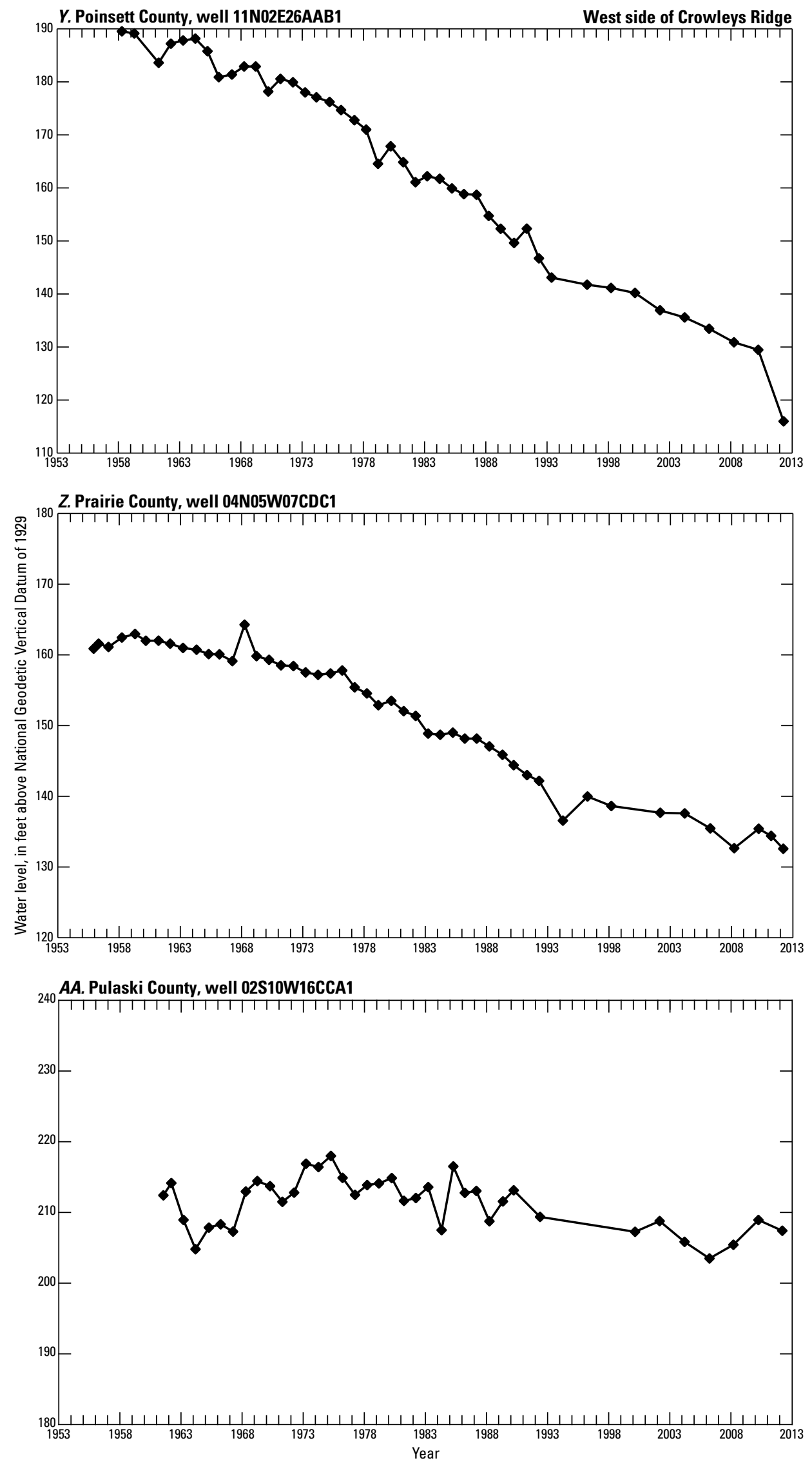

Figure 4. Water-level hydrographs for selected wells completed in the Mississippi River Valley alluvial aquifer in Arkansas.-Continued 

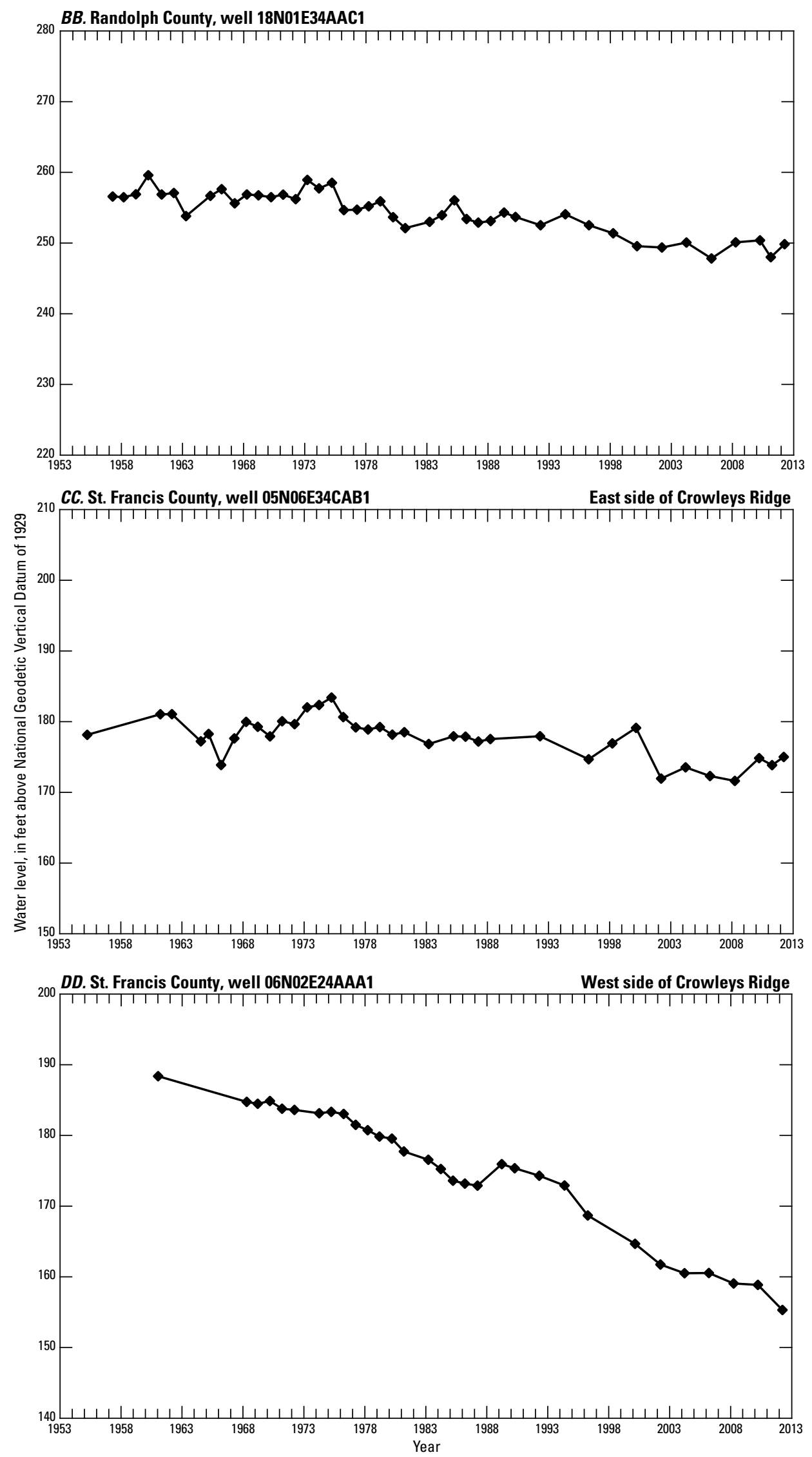

Figure 4. Water-level hydrographs for selected wells completed in the Mississippi River Valley alluvial aquifer in Arkansas.-Continued 


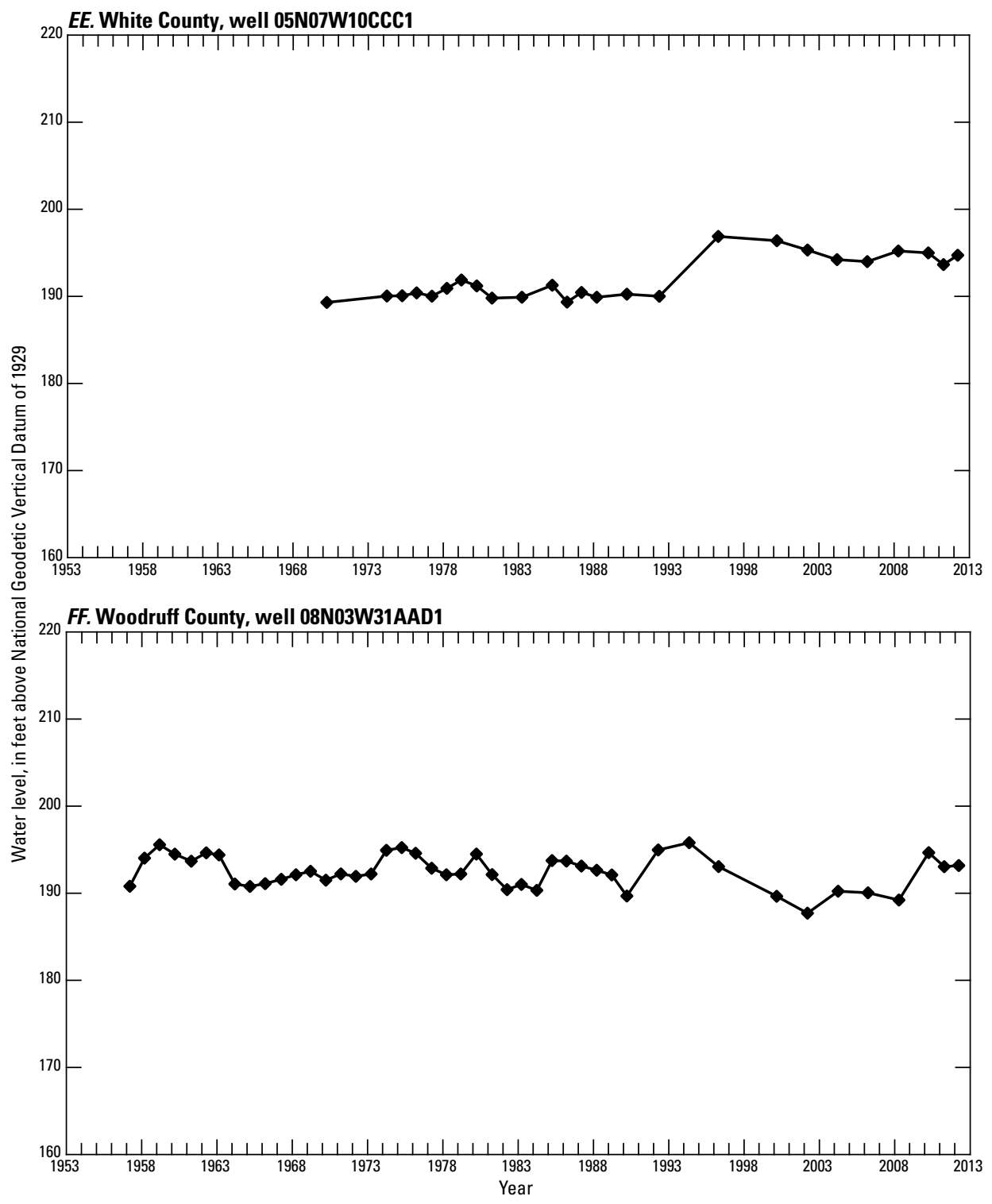

Figure 4. Water-level hydrographs for selected wells completed in the Mississippi River Valley alluvial aquifer in Arkansas.-Continued 


\section{Water-Quality Conditions}

Water samples collected in the summer of 2012 from142 wells completed in the alluvial aquifer were measured onsite for specific conductance, temperature, and $\mathrm{pH}$ (app. 3). Samples were collected from 94 wells for dissolved chloride analysis at the USGS National Water Quality Laboratory (app. 3).

Specific conductance and dissolved chloride have a large range of values and the temperature and $\mathrm{pH}$ have typical ranges for groundwater quality. Specific conductance ranged from 91 microsiemens per centimeter at 25 degrees Celsius ( $\mu \mathrm{S} / \mathrm{cm}$ at $25^{\circ} \mathrm{C}$ ) in Drew County to $984 \mu \mathrm{S} / \mathrm{cm}$ at $25^{\circ} \mathrm{C}$ in Monroe County. The mean specific conductance was $547 \mu \mathrm{S} / \mathrm{cm}$ at $25^{\circ} \mathrm{C}$. The majority of the values are in the $401-600 \mu \mathrm{S} / \mathrm{cm}$ at $25^{\circ} \mathrm{C}$ range (fig. 5). Dissolved chloride concentrations ranged from 3.34 milligrams per liter $(\mathrm{mg} / \mathrm{L})$ in Randolph County to $182 \mathrm{mg} / \mathrm{L}$ in Lincoln County. The mean chloride concentration was $27.6 \mathrm{mg} / \mathrm{L}$. Temperature ranged from $18.1^{\circ} \mathrm{C}$ in Crittenden County to $22.4^{\circ} \mathrm{C}$ in Prairie County. The mean temperature was $20.1^{\circ} \mathrm{C}$. The $\mathrm{pH}$ ranged from 6.2 in Drew County to 8.3 in Randolph County and had a median of 7.3.
Specific-conductance data indicate regionally diverse zones of mineralized water across the study area. Generally, the occurrences of higher specific conductance in the alluvial aquifer are associated with the movement of water containing high concentrations of dissolved solids from sources at depth (Bryant and others, 1985). Water with higher concentrations of dissolved solids may have moved upward where the confining units are thin or absent, along faults, or through unplugged or deteriorated casings of abandoned oil and gas test wells (Fitzpatrick, 1985). Morris and Bush (1986) cite two possible sources of high dissolved-solids concentrations-a zone of groundwater stagnation present in the alluvial aquifer caused by localized restricted horizontal or vertical flow and upward movement of water with higher dissolved-solids concentration from deeper formations in response to pumping. The variability in specific conductance in Lincoln County is explained by the local geomorphology. The specific conductance in Lincoln County ranges from $278 \mu \mathrm{S} / \mathrm{cm}$ to $944 \mu \mathrm{S} / \mathrm{cm}$. Channel deposits have high recharge and permeability, resulting in lower specific conductance. Backswamp deposits have low recharge and permeability and higher evapotranspiration, resulting in higher specific conductance (Kresse and Clark, 2008).

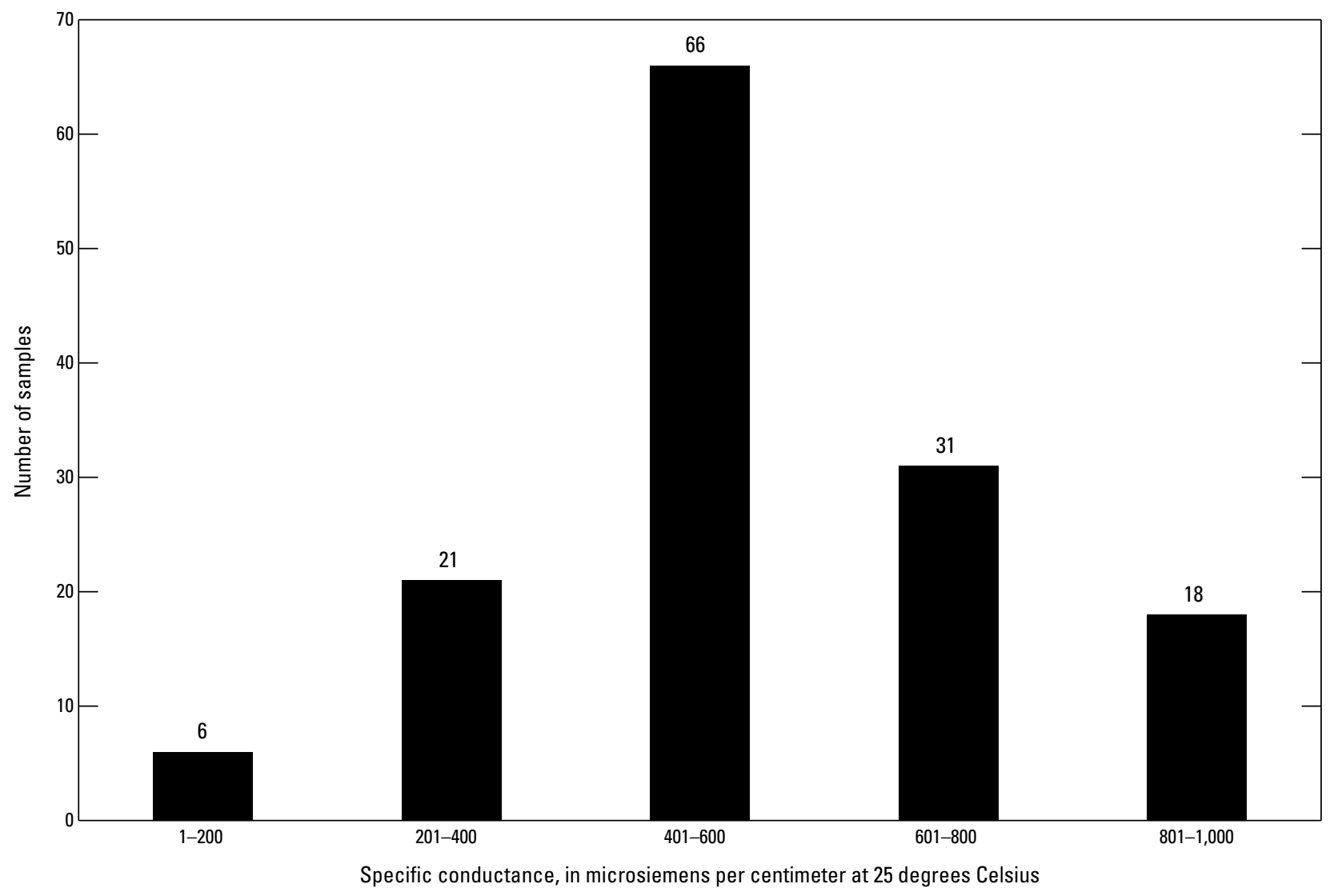

Figure 5. Distribution of specific conductance in samples from the Mississippi River Valley alluvial aquifer in Arkansas, 2012. 


\section{Summary}

The Mississippi Alluvial Plain encompasses an area of approximately 32,000 square miles and includes parts of Arkansas and nearby States. Approximately 54 percent of the Mississippi Alluvial Plain covers the eastern one-third of Arkansas. The Mississippi River Valley alluvial aquifer underlies the Mississippi Alluvial Plain in eastern Arkansas. Within Arkansas, the alluvial aquifer extends from the Missouri State line south to the Louisiana State line, and from the Mississippi River west to the Fall Line and the Monticello Ridge. During the spring of 2012, the U.S. Geological Survey (USGS), in cooperation with the Arkansas Natural Resources Commission (ANRC) and the Arkansas Geological Survey, measured water levels in 342 wells completed in the alluvial aquifer in eastern Arkansas. The ANRC measured water levels in 11 wells and the U.S. Department of AgricultureNatural Resources Conservation Service (NRCS) measured water levels in 239 wells completed in the alluvial aquifer. Information in this report included (1) groundwater levels for spring 2012, (2) a potentiometric-surface map, (3) a water-level difference map comparing water levels from 2008 to 2012, (4) selected water-level hydrographs, and (5) a groundwater water-quality data table for the summer of 2012.

The alluvial aquifer comprises alluvial and terrace deposits of Quaternary age. Lithologically, the Quaternary alluvial and terrace deposits are similar, consisting of unconsolidated sediments that grade from gravel and coarse sand in the lower sections to silt and clay in the upper sections. The coarse sediments contained in the lower sections of the alluvial and terrace deposits are capable of sustaining highyielding wells. Finer sediments in the upper sections of the alluvial and terrace deposits form a confining unit above much of the aquifer. Channel fill, point bar, and backswamp deposits associated with present or former channels of large rivers have produced abrupt changes in lithology and result in large spatial variations in the hydraulic properties of the aquifer.

The alluvial aquifer is increasingly relied upon for agriculture and aquaculture in eastern Arkansas. Water withdrawals from the alluvial aquifer have increased from about 1,063 million gallons per day (Mgal/d) in 1965 to about 7,592 Mgal/d in 2010, an increase of about 614 percent. Withdrawals have more than doubled between 1985 and 2010, an increase of about 115 percent since 1985.

The regional direction of groundwater flow is generally to the south and east except where flow is affected by groundwater withdrawals. East of Crowleys Ridge, water flows from north to south along Crowleys Ridge and northeast to southwest along the Mississippi River. West of Crowleys Ridge, water flows from northeast to southwest along Crowleys Ridge from Clay County to Craighead County. From Craighead County to Monroe County, a depression alters groundwater flow from all directions. A depression in Arkansas, Lonoke, and Prairie Counties alters groundwater flow from all directions. South of the Arkansas River, the flow is towards the southeast, except near the depressions in Lincoln and Desha Counties and Desha and Chicot Counties where flow is towards the depression.

The potentiometric-surface map is based on waterlevel measurements (342 by USGS, 11 by ANRC, and 239 by NRCS) made in 592 wells during the spring of 2012. In 2012, the lowest water-level altitude was 73 feet (ft) in Arkansas County. The highest water-level altitude was $288 \mathrm{ft}$ in northeastern Clay County on the western side of Crowleys Ridge.

The potentiomentric-surface map shows eight depressions, two large depressions and six small depressions. One large depression begins in southeastern Arkansas County, at the Arkansas and Desha County line, extends north into Prairie County, west into Lonoke County and east into the westernmost part of Monroe County. The low water-level altitude measurement in the depression area is $73 \mathrm{ft}$. The area in Lonoke and Prairie Counties in the northwestern half of the depression has a low water-level altitude measurement of $90 \mathrm{ft}$ and expands into the northern third of Prairie County.

The potentiometric-surface map shows a general northsouth depression with the southern end in central Monroe County extending through western Lee, St. Francis, Cross, Poinsett, and Craighead Counties and eastern Woodruff and Jackson Counties. There are two deeper areas in this depression, one at the Monroe and Lee County line, with a low water-level altitude measurement of $123 \mathrm{ft}$, and the second in Poinsett County, with a low water-level altitude measurement of $113 \mathrm{ft}$.

Six small depressions are shown in the potentiometricsurface map - in northern Ashley County, in southern Desha and northern Chicot Counties, in eastern Lincoln and western Chicot Counties, at the Arkansas and Desha County line, in northern Phillips County, and in southeastern Greene County. Continued monitoring of the potentiometric surface will determine if these small depressions are the result of short-term variations or long-term changes in the hydrologic conditions in the alluvial aquifer.

A map showing the difference in water level was constructed using 541 differences in water levels measured during 2008 and 2012. The difference in measured water levels from 2008 to 2012 ranged from -27.4 ft in Lonoke County to $18.7 \mathrm{ft}$ in Prairie County, with a mean of $-1.0 \mathrm{ft}$. Four areas were predominated by declines-west of Crowleys Ridge from Greene County south to Lee County, including Lawrence and southern Woodruff Counties; east of Crowleys Ridge from Clay County south to Poinsett and Mississippi Counties; Lonoke and Jefferson Counties; and Ashley, Chicot, Desha, and Drew Counties. Three areas are predominated by rises in measured water levels-Jackson and northern Woodruff Counties; east of Crowleys Ridge in Crittenden, Cross, St. Francis, and Lee Counties; and White, Prairie, Monroe, Arkansas, and Phillips Counties.

Long-term water-level changes were evaluated using hydrographs from 319 wells in the alluvial aquifer for 
the period from 1988 to 2012. The mean rise or decline for Independence and White Counties had an annual rise from 1988 to 2012. The rise in Independence County was determined from the data of one well. The mean county annual declines between -0.50 feet per year (ft/yr) and $0.00 \mathrm{ft} / \mathrm{yr}$ occurred in Arkansas, Ashley, Chicot, Clay, Crittenden, Drew, Greene, Jefferson, Mississippi, Monroe, Phillips, Prairie, Pulaski, Randolph, and Woodruff Counties. The mean county annual declines between $-1.00 \mathrm{ft} / \mathrm{yr}$ and $-0.50 \mathrm{ft} / \mathrm{yr}$ occurred in Craighead, Cross, Desha, Jackson, Lee, Lincoln, Lonoke, Poinsett, and St. Francis Counties. The mean county annual rises and declines in water level for the entire study area were $-0.45 \mathrm{ft} / \mathrm{yr}$ with a range from -2.08 to $0.84 \mathrm{ft} / \mathrm{yr}$.

Arkansas County has two different rates of annual decline for the two hydrographs shown. Well 04S03W32BCB1 shows an annual water-level decline of about $0.97 \mathrm{ft} / \mathrm{yr}$ since 1988 . Well 07S04W01DDD1 has an annual water-level rise of about $0.26 \mathrm{ft} / \mathrm{yr}$ since 1988 .

In Craighead, Cross, Lee, Poinsett, and St. Francis Counties, water levels are declining at a greater rate west of Crowleys Ridge than water levels are declining east of Crowleys Ridge. Two hydrographs are shown in each of Craighead, Cross, Lee, Poinsett, and St. Francis Counties, one on the west side of Crowleys Ridge and one on the east side of Crowleys Ridge. The hydrographs west of Crowleys Ridge have annual water-level declines from -0.91 to $-1.24 \mathrm{ft} / \mathrm{yr}$ during the period from 1988 to 2012. The hydrographs east of Crowleys Ridge have annual water-level declines from -0.07 to $-0.40 \mathrm{ft} / \mathrm{yr}$ during the period from 1988 to 2012 . The mean county annual decline for these counties was from -0.55 to $-0.87 \mathrm{ft} / \mathrm{yr}$ during the period from 1988 to 2012.

Water samples were collected in the summer of 2012 from 142 wells completed in the alluvial aquifer and measured onsite for specific conductance, temperature, and $\mathrm{pH}$. Samples were collected from 94 wells for dissolved chloride analysis at the USGS National Water Quality Laboratory. Specific conductance ranged from 91 microsiemens per centimeter at 25 degrees Celsius $\left(\mu \mathrm{S} / \mathrm{cm}\right.$ at $\left.25{ }^{\circ} \mathrm{C}\right)$ in Drew County to $984 \mu \mathrm{S} / \mathrm{cm}$ at $25^{\circ} \mathrm{C}$ in Monroe County. The mean specific conductance was $547 \mu \mathrm{S} / \mathrm{cm}$ at $25^{\circ} \mathrm{C}$. Dissolved chloride concentrations ranged from 3.34 milligrams per liter (mg/L) in Randolph County to $182 \mathrm{mg} / \mathrm{L}$ in Lincoln County. The mean chloride concentration was $27.6 \mathrm{mg} / \mathrm{L}$.Temperature ranged from 18.1 degrees Celsius $\left({ }^{\circ} \mathrm{C}\right)$ in Crittenden County to $22.4^{\circ} \mathrm{C}$ in Prairie County. The mean temperature was $22.1^{\circ} \mathrm{C}$. The $\mathrm{pH}$ ranged from 6.2 in Drew County to 8.3 in Randolph County and had a median of 7.3.

\section{Selected References}

Ackerman, D.J., 1996, Hydrology of the Mississippi River Valley alluvial aquifer, south-central United States-A preliminary assessment of the regional flow system: U.S. Geological Survey Professional Paper 1416-D, 56 p.
Boswell, E.H., Cushing, E.M., and Hosman, R.L., 1968, Quaternary aquifers in the Mississippi Embayment, with a discussion of Quality of the water, by H.G. Jeffery: U.S. Geological Survey Professional Paper 448-E, 15 p.

Bryant, C.T., Ludwig, A.H., and Morris, E.E., 1985, Ground water problems in Arkansas: U.S. Geological Survey WaterResources Investigations Report 85-4010, 24 p.

Cunningham, W.L., and Schalk, C.W., comps., 2011, Groundwater technical procedures of the U.S. Geological Survey: U.S. Geological Survey Techniques and Methods, book 1, chap. A1, $151 \mathrm{p}$.

Fenneman, N.M., 1938, Physiography of Eastern United States: New York, McGraw-Hill Book Co. Inc., 689 p.

Fenneman, N.M., and Johnson, D.W., 1946, Physical divisions of the United States (Map): Washington, D.C., U.S. Geological Survey, scale 1:7,000,000.

Fishman, M.J., and Friedman, L.C., 1989, Methods for determination of inorganic substances in water and fluvial sediments: U.S. Geological Survey Techniques of WaterResources Investigations, book 5, chap. A1, 545 p.

Fitzpatrick, D.J., 1985, Occurrence of saltwater in the alluvial aquifer in the Boeuf-Tensas Basin, Arkansas: U.S. Geological Survey Water-Resources Investigation Report 85-4029, 1 sheet.

Gonthier, G.J., and Mahon, G.L., 1993, Thickness of the Mississippi River Valley confining unit, eastern Arkansas: U.S. Geological Survey Water-Resources Investigation Report 92-4121, 4 sheets.

Halberg, H.N., 1972, Use of water in Arkansas, 1970: Arkansas Geological Commission Water Resources Summary Number 7, 17 p.

Halberg, H.N., 1977, Use of water in Arkansas, 1975: Arkansas Geological Commission Water Resources Summary Number 9, 28 p.

Halberg, H.N., and Stephens, J.W., 1966, Use of water in Arkansas, 1965: Arkansas Geological Commission Water Resources Summary Number 5, 12 p.

Helsel, D.R., and Hirsch, R.M., 1992, Statistical methods in water resources: New York, N.Y., Elsevier Science Publishing Co., 522 p.

Holland, T.W., 1987, Use of water in Arkansas, 1985: Arkansas Geological Commission Water Resources Summary Number 14, 30 p.

Holland, T.W., 1993, Use of water in Arkansas, 1990: U.S. Geological Survey Open-File Report 93-48, pamphlet. 
Holland, T.W., 1999, Water use in Arkansas, 1995: U.S. Geological Survey Open-File Report 99-188, 1 sheet.

Holland, T.W., 2004, Estimated water use in Arkansas, 2000: U.S. Geological Survey Scientific Investigations Report 2004-5230, 31 p.

Holland, T.W., 2007, Water use in Arkansas, 2005: U.S. Geological Survey Scientific Investigations Report $2007-$ 5241, 31 p.

Holland, T.W., and Ludwig, A.H., 1981, Use of water in Arkansas, 1980: Arkansas Geological Commission Water Resources Summary Number 14, 30 p.

Kresse, T.M., and Clark, B.R., 2008, Occurrence, distribution, sources, and trends of elevated chloride concentrations in the Mississippi River Valley alluvial aquifer in southeastern Arkansas: U.S. Geological Survey Scientific Investigations Report 2008-5193, 34 p.

Joseph, R.L., 1999, Status of water levels and selected water-quality conditions in the Mississippi River Valley alluvial aquifer in eastern Arkansas, 1998: U.S. Geological Survey Water-Resources Investigations Report 99-4035, $54 \mathrm{p}$.

Mahon, G.L., and Poynter, D.T., 1993, Development, calibration, and testing of ground-water flow models for the Mississippi River Valley alluvial aquifer in eastern Arkansas using one-square mile cells: U.S. Geological Survey WaterResources Investigations Report 92-4106, 33 p.

Morris, E.E., and Bush, W.V., 1986, Extent and source of saltwater intrusion into the alluvial aquifer near Brinkley, Arkansas, 1984: U.S. Geological Survey Water-Resources Investigations Report 85-4322, 123 p.
Reed, T.B., 2004, Status of water levels and selected waterquality conditions in the Mississippi River Valley alluvial aquifer in eastern Arkansas, 2002: U.S. Geological Survey Scientific Investigations Report 2004-5129, 53 p.

Schrader, T.P., 2001, Status of water levels and selected waterquality conditions in the Mississippi River Valley alluvial aquifer in eastern Arkansas, 2000: U.S. Geological Survey Water-Resources Investigations Report 01-4124, 52 p.

Schrader, T.P., 2006, Status of water levels and selected waterquality conditions in the Mississippi River Valley alluvial aquifer in eastern Arkansas, 2004: U.S. Geological Survey Scientific Investigations Report 2006-5128, 82 p.

Schrader, T.P., 2008, Water levels and selected water-quality conditions in the Mississippi River Valley alluvial aquifer in eastern Arkansas, 2006: U.S. Geological Survey Scientific Investigations Report 2008-5092, 72 p.

Schrader, T.P., 2010, Water levels and selected water-quality conditions in the Mississippi River Valley alluvial aquifer in eastern Arkansas, 2008: U.S. Geological Survey Scientific Investigations Report 2010-5140, 71 p.

Stanton, G.P., Joseph, R.L., and Pugh, A.L., 1998, Status of water levels and selected water-quality conditions in the Mississippi River Valley alluvial aquifer in eastern Arkansas, 1994-1996: U.S. Geological Survey WaterResources Investigations Report 98-4131, 72 p.

U.S. Geological Survey, variously dated, National field manual for the collection of water-quality data: U.S. Geological Survey Techniques of Water-Resources Investigations, book 9, chaps. A1-A9, available at http://pubs.water.usgs. gov/twri9A. 



\section{Appendixes}



Appendix 1. Water levels measured in wells completed in the Mississippi River Valley alluvial aquifer in eastern Arkansas, 2012.

[USGS, U.S. Geological Survey; NRCS, Natural Resources Conservation Service, ANRC, Arkansas Natural Resources Commission; --, no data; NGVD 29, National Geodetic Vertical Datum of 1929; Horizontal coordinate information is referenced to the North American Datum of 1983 (NAD 83)]

\begin{tabular}{|c|c|c|c|c|c|c|c|c|}
\hline Station name & $\begin{array}{c}\text { Latitude } \\
\text { (degrees, } \\
\text { minutes, } \\
\text { seconds) }\end{array}$ & $\begin{array}{l}\text { Longitude } \\
\text { (degrees, } \\
\text { minutes, } \\
\text { seconds) }\end{array}$ & $\begin{array}{l}\text { Source } \\
\text { of data }\end{array}$ & $\begin{array}{l}\text { Depth } \\
\text { of well } \\
\text { (feet) }\end{array}$ & $\begin{array}{l}\text { Land-surface } \\
\text { datum altitude } \\
\text { (feet above } \\
\text { NGVD 29) }\end{array}$ & $\begin{array}{l}\text { Depth to water } \\
\text { (feet below } \\
\text { land-surface } \\
\text { datum) }\end{array}$ & $\begin{array}{c}\text { Water-level } \\
\text { altitude } \\
\text { (feet above } \\
\text { NGVD 29) }\end{array}$ & $\begin{array}{c}\text { Date of } \\
\text { measurement }\end{array}$ \\
\hline \multicolumn{9}{|c|}{ Arkansas County } \\
\hline 02S04W11DBB1 & 343233 & 912415 & USGS & 152 & 213.04 & 100.08 & 113 & 03/15/2012 \\
\hline 02S05W15AAB1 & 343213 & 913127 & USGS & 180 & 213 & 123.23 & 90 & 03/15/2012 \\
\hline 03S02W27ABB1 & 342448 & 911251 & USGS & 87 & 197 & 62.76 & 134 & 03/14/2012 \\
\hline 03S03W05CCD1 & 342737 & 912132 & USGS & 150 & 201 & 99.78 & 101 & 03/14/2012 \\
\hline 03S03W18CCC1 & 342553 & 912251 & USGS & 152.5 & 196 & 100.58 & 95 & 03/15/2012 \\
\hline 03S03W27BBC1 & 342455 & 911944 & USGS & 120 & 195 & 93.09 & 102 & 03/15/2012 \\
\hline 03S04W02BBB1 & 342831 & 912454 & USGS & 116 & 197.63 & 93.35 & 104 & 03/15/2012 \\
\hline 03S04W03DCA16 & 342753 & 912515 & USGS & 126 & 205 & 101.29 & 104 & 04/24/2012 \\
\hline 03S04W03DCA6 & 342753 & 912517 & USGS & 122.3 & 204 & 100.41 & 104 & 03/15/2012 \\
\hline 03S04W03DDA1 & 342750 & 912460 & USGS & 127 & 202 & 105.19 & 97 & 03/15/2012 \\
\hline 03S05W03CCC1 & 342752 & 913227 & USGS & 110 & 215 & 103.88 & 111 & 03/15/2012 \\
\hline 03S05W13CBA2 & 342630 & 913007 & USGS & 136.25 & 211 & 106.98 & 104 & 03/15/2012 \\
\hline 03S06W35ADD1 & 342411 & 913652 & USGS & -- & 190 & 59.93 & 130 & 03/15/2012 \\
\hline 04S01W04ACD2 & 342233 & 910733 & USGS & 52.4 & 155 & 8.24 & 147 & 03/14/2012 \\
\hline 04S01W19AAD1 & 342012 & 910919 & USGS & 157.2 & 196 & 62.44 & 134 & 03/14/2012 \\
\hline 04S01W31DCB1 & 341753 & 910949 & USGS & 130 & 179 & 50.04 & 129 & 03/14/2012 \\
\hline 04S02W29CCC1 & 341846 & 911539 & USGS & 140 & 191 & 85.20 & 106 & 03/14/2012 \\
\hline 04S03W17ADD1 & 342102 & 912058 & USGS & -- & 200 & 111.77 & 88 & 03/15/2012 \\
\hline 04S03W32BCB1 & 341820 & 912202 & USGS & -- & 192 & 118.85 & 73 & 03/15/2012 \\
\hline 04S04W02ABB1 & 342313 & 912424 & USGS & 155 & 200 & 110.06 & 90 & 03/15/2012 \\
\hline 04S04W35ABC1 & 341835 & 912437 & NRCS & -- & 193 & 91.2 & 102 & 03/06/2012 \\
\hline 04S06W15DBB1 & 342122 & 913827 & USGS & 100 & 190 & 34.42 & 156 & 03/15/2012 \\
\hline 05S01W16BAB1 & 341552 & 910729 & USGS & -- & 183 & 45.90 & 137 & 03/14/2012 \\
\hline 05S02W16ABD1 & 341552 & 911358 & USGS & 154 & 190 & 80.31 & 110 & 03/14/2012 \\
\hline 05S03W09CBA1 & 341624 & 912046 & USGS & 180.5 & 196 & 114.71 & 81 & 03/15/2012 \\
\hline 05S04W07CCC1 & 341555 & 912932 & USGS & 120 & 194 & 73.88 & 120 & 03/15/2012 \\
\hline 05S04W32BBA1 & 341316 & 912822 & USGS & -- & 191 & 56.62 & 134 & 03/15/2012 \\
\hline 05S06W02DDD1 & 341724 & 913651 & USGS & 60 & 182.93 & 21.98 & 161 & 03/15/2012 \\
\hline 05S06W07DDC1 & 341642 & 914130 & USGS & 32 & 180.48 & -3.20 & 184 & 03/15/2012 \\
\hline 06S02W23DCD1 & 340853 & 911206 & USGS & -- & 188 & 74.20 & 114 & 03/14/2012 \\
\hline 06S03W10BBA1 & 341136 & 911954 & USGS & 155 & 184 & 79.36 & 105 & 03/14/2012 \\
\hline 06S03W27AAA1 & 340858 & 911913 & USGS & 132 & 183.14 & 68.28 & 115 & 03/14/2012 \\
\hline 06S03W32ADD1 & 340740 & 912115 & USGS & 135.5 & 180 & 56.82 & 123 & 03/14/2012 \\
\hline 07S02W04BBB1 & 340707 & 911452 & USGS & -- & 176 & 49.26 & 127 & 03/14/2012 \\
\hline 07S02W17BBA1 & 340530 & 911539 & USGS & 95 & 184 & 48.89 & 135 & 03/14/2012 \\
\hline 07S03W18CCD1 & 340435 & 912316 & USGS & -- & 186.18 & 41.34 & 145 & 03/14/2012 \\
\hline 07S03W32BBC1 & 340240 & 912216 & USGS & 128 & 176.92 & 24.22 & 153 & 03/14/2012 \\
\hline
\end{tabular}


Appendix 1. Water levels measured in wells completed in the Mississippi River Valley alluvial aquifer in eastern Arkansas, 2012.Continued

[USGS, U.S. Geological Survey; NRCS, Natural Resources Conservation Service, ANRC, Arkansas Natural Resources Commission; --, no data; NGVD 29, National Geodetic Vertical Datum of 1929; Horizontal coordinate information is referenced to the North American Datum of 1983 (NAD 83)]

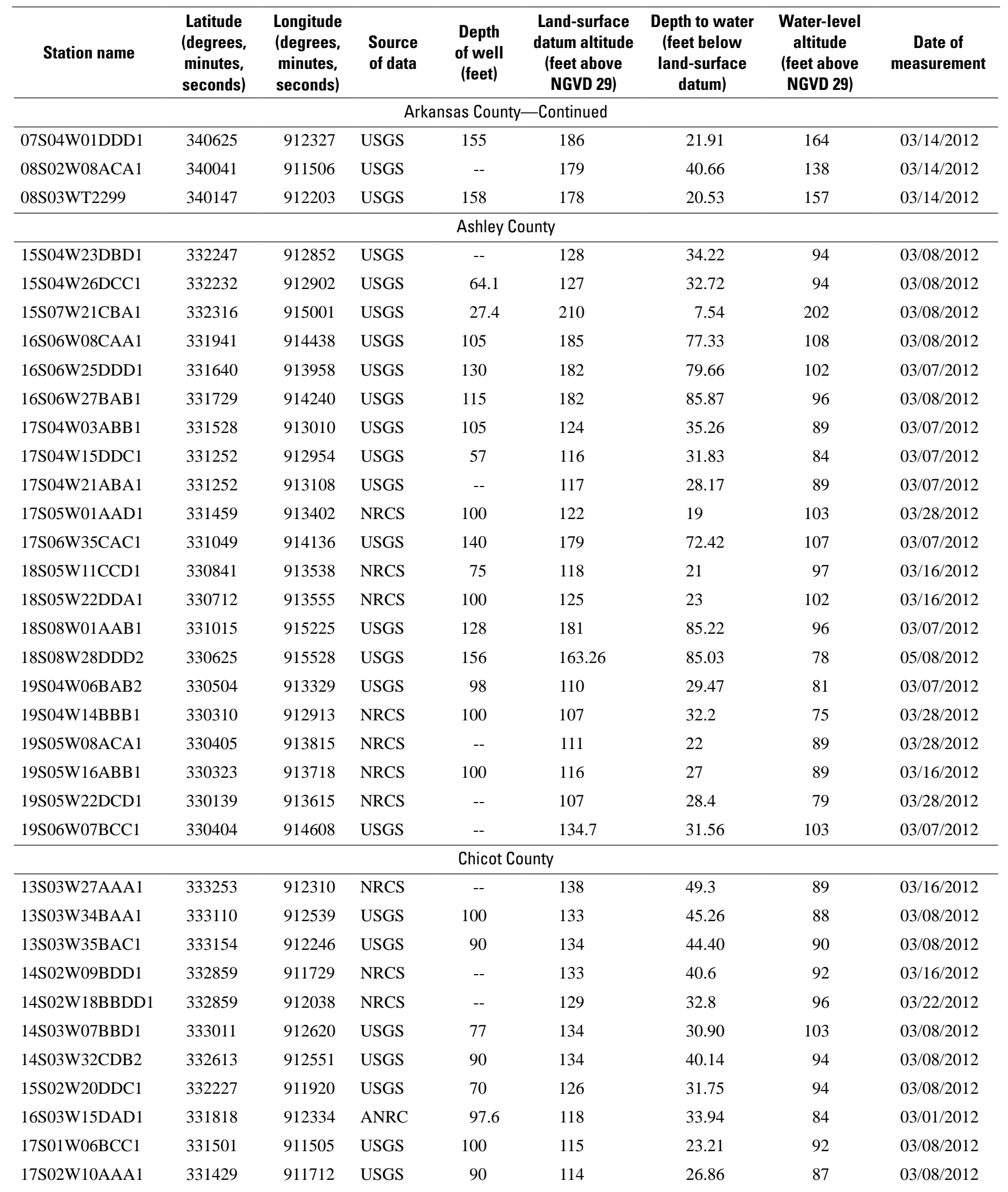


Appendix 1. Water levels measured in wells completed in the Mississippi River Valley alluvial aquifer in eastern Arkansas, 2012.Continued

[USGS, U.S. Geological Survey; NRCS, Natural Resources Conservation Service, ANRC, Arkansas Natural Resources Commission; --, no data; NGVD 29, National Geodetic Vertical Datum of 1929; Horizontal coordinate information is referenced to the North American Datum of 1983 (NAD 83)]

\begin{tabular}{|c|c|c|c|c|c|c|c|c|}
\hline Station name & $\begin{array}{l}\text { Latitude } \\
\text { (degrees, } \\
\text { minutes, } \\
\text { seconds) }\end{array}$ & $\begin{array}{l}\text { Longitude } \\
\text { (degrees, } \\
\text { minutes, } \\
\text { seconds) }\end{array}$ & $\begin{array}{l}\text { Source } \\
\text { of data }\end{array}$ & $\begin{array}{l}\text { Depth } \\
\text { of well } \\
\text { (feet) }\end{array}$ & $\begin{array}{l}\text { Land-surface } \\
\text { datum altitude } \\
\text { (feet above } \\
\text { NGVD 29) }\end{array}$ & $\begin{array}{l}\text { Depth to water } \\
\text { (feet below } \\
\text { land-surface } \\
\text { datum) }\end{array}$ & $\begin{array}{c}\text { Water-level } \\
\text { altitude } \\
\text { (feet above } \\
\text { NGVD 29) }\end{array}$ & $\begin{array}{c}\text { Date of } \\
\text { measurement }\end{array}$ \\
\hline 17S03W18CBC1 & 331257 & 912736 & NRCS & -- & 117 & 35.6 & 81 & 03/27/2012 \\
\hline 17S03W28DBA1 & 331127 & 912441 & USGS & 95 & 110 & 25.63 & 84 & 03/08/2012 \\
\hline 19S03W14ABB1 & 330304 & 912251 & USGS & 95 & 111 & 24.22 & 87 & 03/08/2012 \\
\hline \multicolumn{9}{|c|}{ Clay County } \\
\hline 18N08E03DAB1 & 361323 & 901153 & USGS & 105 & 257 & 7.27 & 250 & $04 / 11 / 2012$ \\
\hline 18N08E11BAA1 & 361253 & 901117 & NRCS & 100 & 259 & 7.6 & 251 & 04/03/2012 \\
\hline 19N05E15BBD1 & 361716 & 903152 & NRCS & 110 & 289 & 37.3 & 252 & 04/02/2012 \\
\hline 19N06E18DBC1 & 361642 & 902815 & NRCS & -- & 297 & 41.1 & 256 & 04/03/2012 \\
\hline 19N07E25BCB1 & 361519 & 901700 & NRCS & -- & 268 & 16.6 & 251 & 04/03/2012 \\
\hline 19N08E08DCA1 & 361729 & 901402 & NRCS & -- & 270 & 4.9 & 265 & 04/03/2012 \\
\hline 19N09E19CDC1 & 361539 & 900908 & NRCS & -- & 265 & 6.9 & 258 & 04/03/2012 \\
\hline 20N03E25BAA1 & 362112 & 904225 & NRCS & 100 & 288 & 8.8 & 279 & 04/02/2012 \\
\hline 20N04E03ADA1 & 362425 & 903725 & NRCS & -- & 290 & 13.9 & 276 & 04/02/2012 \\
\hline 20N05E22CAD1 & 362118 & 903132 & NRCS & -- & 290 & 29 & 261 & $04 / 02 / 2012$ \\
\hline 20N09E09ABC1 & 362306 & 900642 & NRCS & -- & 279 & 5.4 & 274 & 04/03/2012 \\
\hline 20N09E33DDC1 & 361904 & 900628 & NRCS & -- & 270 & 6.4 & 264 & 04/03/2012 \\
\hline 21N03E15CBC1 & 362738 & 904453 & NRCS & 90 & 292 & 10.8 & 281 & 04/02/2012 \\
\hline 21N03E36CDD1 & 362450 & 904214 & NRCS & -- & 290 & 10.5 & 280 & $04 / 02 / 2012$ \\
\hline 21N04E09DBC1 & 362828 & 903853 & NRCS & -- & 291 & 12 & 279 & 04/02/2012 \\
\hline 21N05E17ABB1 & 362755 & 903329 & USGS & 105 & 298 & 24.36 & 274 & 04/11/2012 \\
\hline 21N05E22BAB1 & 362704 & 903132 & NRCS & 105 & 288 & 2.1 & 286 & 04/02/2012 \\
\hline 21N06E11BBB1 & 362839 & 902421 & NRCS & 100 & 296 & 14.8 & 281 & 04/03/2012 \\
\hline 21N06E28BB1 & 362605 & 902608 & USGS & 130 & 292.5 & 19.90 & 273 & 04/11/2012 \\
\hline 21N07E01DDC1 & 362835 & 901607 & NRCS & 90 & 303 & 25.2 & 278 & 04/03/2012 \\
\hline 21N08E03CDB1 & 362848 & 901217 & NRCS & -- & 308 & 20.4 & 288 & 04/03/2012 \\
\hline 21N08E18CCC1 & 362651 & 901550 & USGS & 110 & 324 & 43.03 & 281 & 04/11/2012 \\
\hline 21N09E31BDA1 & 362447 & 900851 & NRCS & 100 & 284 & 5.2 & 279 & 04/03/2012 \\
\hline
\end{tabular}


Appendix 1. Water levels measured in wells completed in the Mississippi River Valley alluvial aquifer in eastern Arkansas, 2012.Continued

[USGS, U.S. Geological Survey; NRCS, Natural Resources Conservation Service, ANRC, Arkansas Natural Resources Commission; --, no data; NGVD 29, National Geodetic Vertical Datum of 1929; Horizontal coordinate information is referenced to the North American Datum of 1983 (NAD 83)]

\begin{tabular}{|c|c|c|c|c|c|c|c|c|}
\hline Station name & $\begin{array}{l}\text { Latitude } \\
\text { (degrees, } \\
\text { minutes, } \\
\text { seconds) }\end{array}$ & $\begin{array}{c}\text { Longitude } \\
\text { (degrees, } \\
\text { minutes, } \\
\text { seconds) }\end{array}$ & $\begin{array}{l}\text { Source } \\
\text { of data }\end{array}$ & $\begin{array}{l}\text { Depth } \\
\text { of well } \\
\text { (feet) }\end{array}$ & $\begin{array}{c}\text { Land-surface } \\
\text { datum altitude } \\
\text { (feet above } \\
\text { NGVD 29) }\end{array}$ & $\begin{array}{c}\text { Depth to water } \\
\text { (feet below } \\
\text { land-surface } \\
\text { datum) }\end{array}$ & $\begin{array}{c}\text { Water-level } \\
\text { altitude } \\
\text { (feet above } \\
\text { NGVD 29) }\end{array}$ & $\begin{array}{c}\text { Date of } \\
\text { measurement }\end{array}$ \\
\hline \multicolumn{9}{|c|}{ Craighead County } \\
\hline 13N01E23CAB1 & 354430 & 905736 & NRCS & 118 & 245 & 72.2 & 173 & 04/04/2012 \\
\hline 13N01E23DAA1 & 354435 & 905652 & USGS & 118 & 242 & 74.07 & 168 & 04/10/2012 \\
\hline 13N03E29AAA1 & 354403 & 904713 & USGS & 122 & 251 & 111.31 & 140 & 04/10/2012 \\
\hline 13N04E12ABB1 & 354635 & 903656 & USGS & 110 & 231 & 25.61 & 205 & 04/09/2012 \\
\hline 13N04E15DBA1 & 354521 & 903857 & NRCS & 130 & 230 & 25.7 & 204 & 03/20/2012 \\
\hline 13N04E26BCC1 & 354340 & 903829 & NRCS & 100 & 225 & 27.5 & 198 & 03/20/2012 \\
\hline 13N07E02CAB1 & 354642 & 901901 & NRCS & 120 & 226 & 10.0 & 216 & 03/20/2012 \\
\hline 13N07E05ABB1 & 354716 & 902158 & NRCS & 100 & 225 & 7.3 & 218 & 03/20/2012 \\
\hline 13N07E20BBA1 & 354440 & 902216 & USGS & 22.3 & 223.2 & 4.92 & 218 & 04/10/2012 \\
\hline 13N07E35BCD1 & 354233 & 901837 & NRCS & 120 & 221 & 14.0 & 207 & 03/20/2012 \\
\hline 14N01E03ACB1 & 355246 & 905816 & NRCS & 96 & 249 & 55.5 & 194 & 04/04/2012 \\
\hline 14N01E10BAB1 & 355204 & 905828 & NRCS & 96 & 246 & 59.4 & 187 & 04/04/2012 \\
\hline 14N01E31DCA1 & 354817 & 910121 & NRCS & 126 & 251 & 66.5 & 185 & 04/04/2012 \\
\hline 14N02E18BDD1 & 355041 & 905419 & USGS & 120 & 242 & 60.40 & 182 & 04/10/2012 \\
\hline 14N07E26DBB1 & 354834 & 901843 & USGS & 100 & 228 & 7.05 & 221 & 04/10/2012 \\
\hline 15N02E12DCB1 & 355626 & 904930 & NRCS & 120 & 250 & 37.7 & 212 & 04/04/2012 \\
\hline 15N05E22BAB1 & 355513 & 903241 & NRCS & 197 & 260 & 36.2 & 224 & 03/20/2012 \\
\hline 15N06E04BAD1 & 355744 & 902706 & NRCS & 104 & 239 & 17.5 & 222 & 03/20/2012 \\
\hline 15N06E20DDD1 & 355426 & 902739 & USGS & -- & 234 & 9.73 & 224 & 04/10/2012 \\
\hline 15N07E35DCB1 & 355241 & 901831 & NRCS & 120 & 231 & 14.5 & 217 & 03/20/2012 \\
\hline \multicolumn{9}{|c|}{ Crittenden County } \\
\hline 04N07E21AAD1 & 345644 & 902121 & USGS & 82.1 & 202 & 9.87 & 192 & $04 / 09 / 2012$ \\
\hline 05N07E28CBA1 & 350121 & 902140 & USGS & -- & 201 & 16.06 & 185 & 04/09/2012 \\
\hline 05N07E34BAB1 & 350059 & 902030 & USGS & 100 & 203 & 14.36 & 189 & 04/09/2012 \\
\hline 05N08E11CCD2 & 350345 & 901308 & USGS & 63 & 211 & 24.91 & 186 & 04/09/2012 \\
\hline 06N07E13BAA1 & 350850 & 901808 & USGS & 130 & 205 & 20.79 & 184 & 04/09/2012 \\
\hline 07N07E05DAD1 & 351504 & 902129 & USGS & 132 & 215 & 30.98 & 184 & 04/09/2012 \\
\hline
\end{tabular}


Appendix 1. Water levels measured in wells completed in the Mississippi River Valley alluvial aquifer in eastern Arkansas, 2012.Continued

[USGS, U.S. Geological Survey; NRCS, Natural Resources Conservation Service, ANRC, Arkansas Natural Resources Commission; --, no data; NGVD 29, National Geodetic Vertical Datum of 1929; Horizontal coordinate information is referenced to the North American Datum of 1983 (NAD 83)]

\begin{tabular}{|c|c|c|c|c|c|c|c|c|}
\hline Station name & $\begin{array}{l}\text { Latitude } \\
\text { (degrees, } \\
\text { minutes, } \\
\text { seconds) }\end{array}$ & $\begin{array}{l}\text { Longitude } \\
\text { (degrees, } \\
\text { minutes, } \\
\text { seconds) }\end{array}$ & $\begin{array}{l}\text { Source } \\
\text { of data }\end{array}$ & $\begin{array}{l}\text { Depth } \\
\text { of well } \\
\text { (feet) }\end{array}$ & $\begin{array}{l}\text { Land-surface } \\
\text { datum altitude } \\
\text { (feet above } \\
\text { NGVD 29) }\end{array}$ & $\begin{array}{l}\text { Depth to water } \\
\text { (feet below } \\
\text { land-surface } \\
\text { datum) }\end{array}$ & $\begin{array}{c}\text { Water-level } \\
\text { altitude } \\
\text { (feet above } \\
\text { NGVD 29) }\end{array}$ & $\begin{array}{c}\text { Date of } \\
\text { measurement }\end{array}$ \\
\hline 07N07E31CCC1 & 351042 & 902359 & USGS & 110 & 207 & 36.53 & 170 & 04/09/2012 \\
\hline 07N09E05CDD1 & 351453 & 900934 & USGS & 120 & 214 & 9.46 & 205 & 04/09/2012 \\
\hline 08N07E14DAA2 & 351854 & 901833 & USGS & -- & 219 & 32.62 & 186 & 04/09/2012 \\
\hline 08N07E35BBC1 & 351630 & 901933 & ANRC & 140.8 & 221 & 32.56 & 188 & 03/14/2012 \\
\hline 09N07E10DDA1 & 352448 & 901925 & USGS & 60 & 221 & 28.84 & 192 & 04/09/2012 \\
\hline 09N07E31BAB1 & 352160 & 902327 & USGS & 110 & 221 & 33.20 & 188 & 04/09/2012 \\
\hline 07N01E05CDA1 & 351518 & 910049 & USGS & 140 & 217 & 80.07 & 137 & 05/01/2012 \\
\hline 07N01E05DCA1 & 351514 & 910033 & NRCS & 160 & 215 & 78.5 & 137 & 04/02/2012 \\
\hline 07N01E06CAA1 & 351530 & 910154 & NRCS & -- & 220 & 76.6 & 143 & 04/02/2012 \\
\hline 07N01E11AAA1 & 351501 & 905705 & USGS & 120 & 217 & 80.28 & 137 & 05/01/2012 \\
\hline 07N01E33BBA1 & 351134 & 910010 & NRCS & -- & 215 & 72 & 143 & 04/02/2012 \\
\hline 07N02E02CDD1 & 351508 & 905113 & ANRC & 149.9 & 225 & 84.14 & 141 & 03/14/2012 \\
\hline 07N02E10ABB1 & 351504 & 905217 & NRCS & -- & 230 & 92 & 138 & 04/02/2012 \\
\hline 07N02E12BBC1 & 351447 & 905040 & NRCS & 100 & 225 & 81 & 144 & $04 / 02 / 2012$ \\
\hline 07N04E27BDA1 & 351220 & 903926 & NRCS & -- & 203 & 26.5 & 177 & 04/02/2012 \\
\hline 07N05E02AAB1 & 351600 & 903103 & NRCS & -- & 210 & 42.5 & 168 & 04/02/2012 \\
\hline 07N05E16ACA1 & 351358 & 903352 & NRCS & -- & 210 & 35 & 175 & 04/02/2012 \\
\hline 07N05E19CCC1 & 351238 & 903645 & USGS & -- & 207 & 35.96 & 171 & 05/01/2012 \\
\hline 07N05E25ABA1 & 351229 & 903045 & USGS & 140 & 205 & 38.28 & 167 & 05/01/2012 \\
\hline 08N01E02CDD1 & 352023 & 905736 & NRCS & -- & 226 & 93 & 133 & 04/03/2012 \\
\hline 08N01E16DBB1 & 351855 & 905933 & NRCS & 140 & 225 & 90.5 & 135 & 04/03/2012 \\
\hline 08N01E17CAD1 & 351852 & 910046 & NRCS & -- & 220 & 78 & 142 & 04/03/2012 \\
\hline 08N02E12DCC1 & 351938 & 905002 & NRCS & -- & 230 & 98 & 132 & 04/03/2012 \\
\hline 08N02E17AAA1 & 351923 & 905354 & NRCS & -- & 225 & 94 & 131 & 04/02/2012 \\
\hline 08N05E17CAA1 & 351904 & 903508 & NRCS & -- & 211 & 32 & 179 & 04/02/2012 \\
\hline 08N05E32ADD1 & 351632 & 903440 & USGS & -- & 204 & 27.23 & 177 & 05/01/2012 \\
\hline 09N01E04ACD1 & 352608 & 905914 & NRCS & 140 & 225 & 93.5 & 132 & 04/03/2012 \\
\hline
\end{tabular}


Appendix 1. Water levels measured in wells completed in the Mississippi River Valley alluvial aquifer in eastern Arkansas, 2012.Continued

[USGS, U.S. Geological Survey; NRCS, Natural Resources Conservation Service, ANRC, Arkansas Natural Resources Commission; --, no data; NGVD 29, National Geodetic Vertical Datum of 1929; Horizontal coordinate information is referenced to the North American Datum of 1983 (NAD 83)]

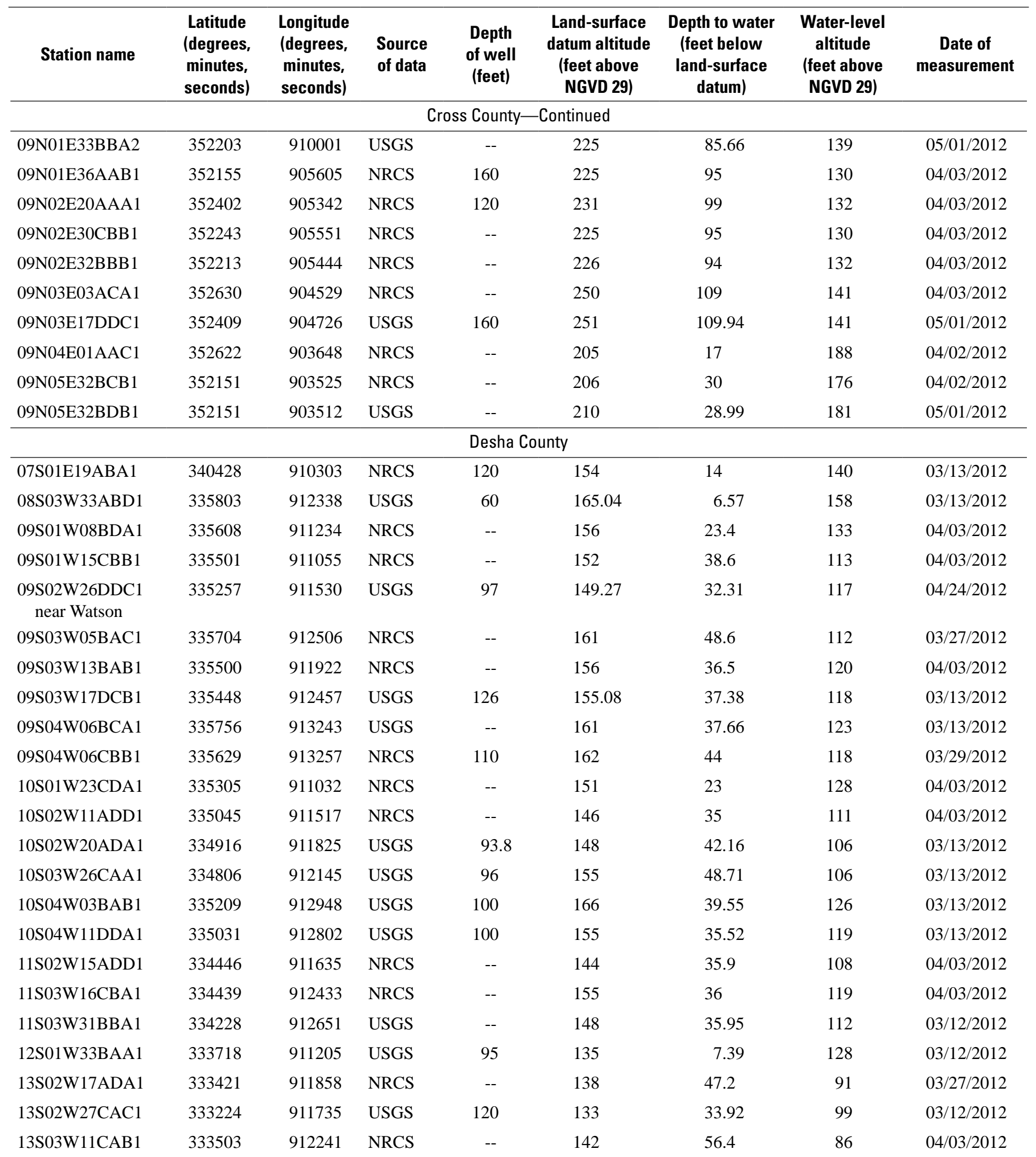


Appendix 1. Water levels measured in wells completed in the Mississippi River Valley alluvial aquifer in eastern Arkansas, 2012.Continued

[USGS, U.S. Geological Survey; NRCS, Natural Resources Conservation Service, ANRC, Arkansas Natural Resources Commission; --, no data; NGVD 29, National Geodetic Vertical Datum of 1929; Horizontal coordinate information is referenced to the North American Datum of 1983 (NAD 83)]

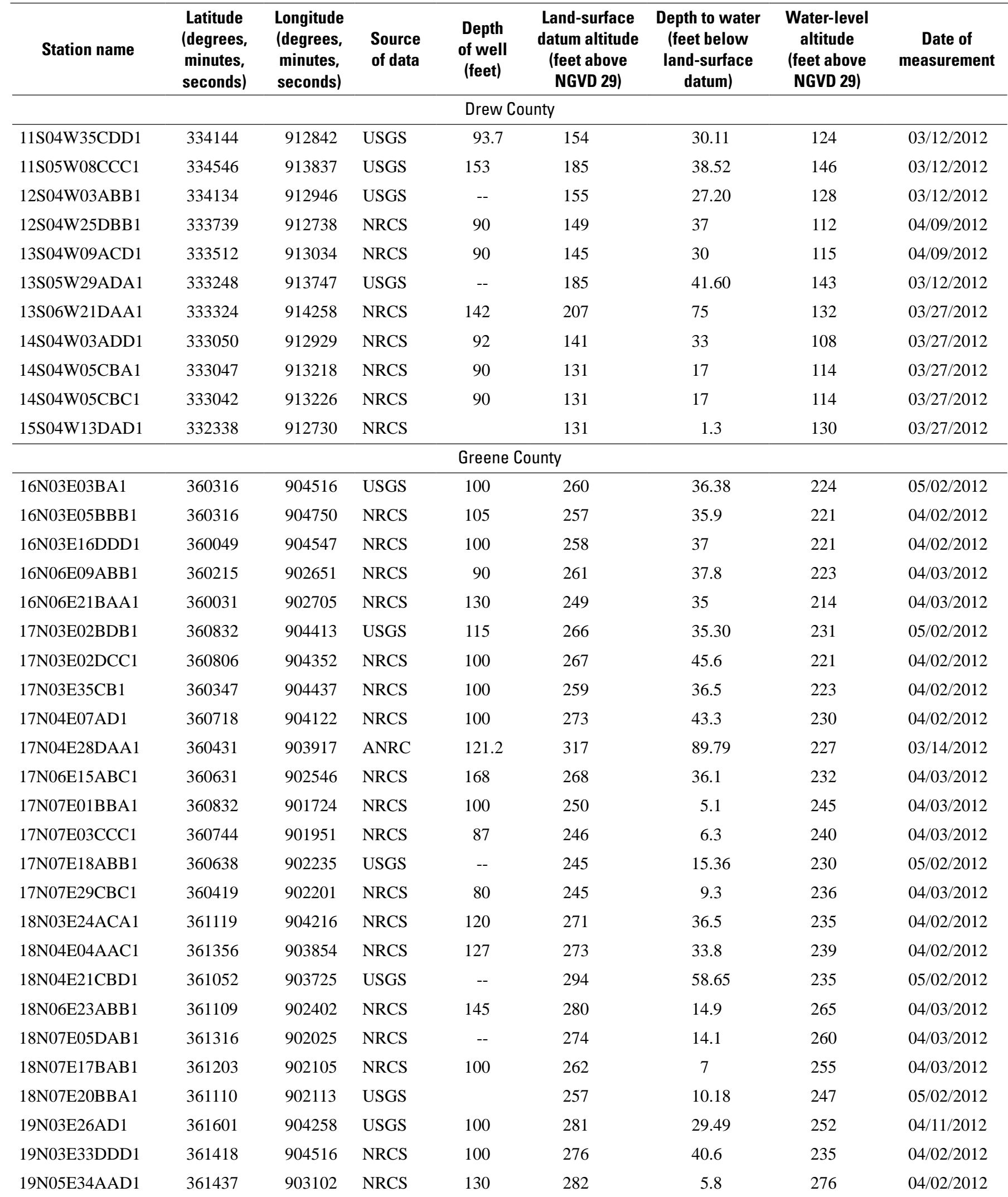


Appendix 1. Water levels measured in wells completed in the Mississippi River Valley alluvial aquifer in eastern Arkansas, 2012.Continued

[USGS, U.S. Geological Survey; NRCS, Natural Resources Conservation Service, ANRC, Arkansas Natural Resources Commission; --, no data; NGVD 29, National Geodetic Vertical Datum of 1929; Horizontal coordinate information is referenced to the North American Datum of 1983 (NAD 83)]

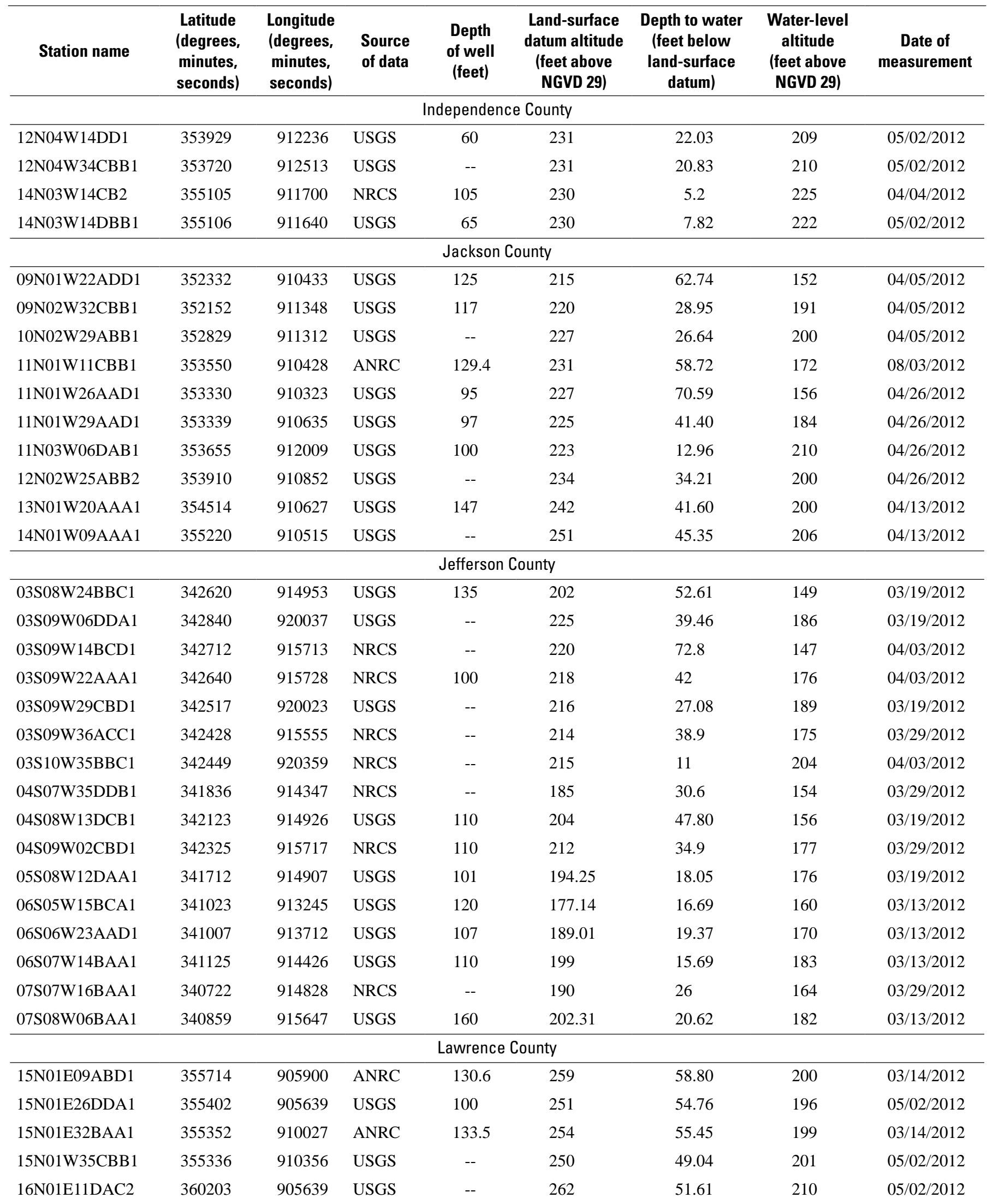


Appendix 1. Water levels measured in wells completed in the Mississippi River Valley alluvial aquifer in eastern Arkansas, 2012.Continued

[USGS, U.S. Geological Survey; NRCS, Natural Resources Conservation Service, ANRC, Arkansas Natural Resources Commission; --, no data; NGVD 29, National Geodetic Vertical Datum of 1929; Horizontal coordinate information is referenced to the North American Datum of 1983 (NAD 83)]

\begin{tabular}{|c|c|c|c|c|c|c|c|c|}
\hline Station name & $\begin{array}{l}\text { Latitude } \\
\text { (degrees, } \\
\text { minutes, } \\
\text { seconds) }\end{array}$ & $\begin{array}{l}\text { Longitude } \\
\text { (degrees, } \\
\text { minutes, } \\
\text { seconds) }\end{array}$ & $\begin{array}{l}\text { Source } \\
\text { of data }\end{array}$ & $\begin{array}{l}\text { Depth } \\
\text { of well } \\
\text { (feet) }\end{array}$ & $\begin{array}{l}\text { Land-surface } \\
\text { datum altitude } \\
\text { (feet above } \\
\text { NGVD 29) }\end{array}$ & $\begin{array}{l}\text { Depth to water } \\
\text { (feet below } \\
\text { land-surface } \\
\text { datum) }\end{array}$ & $\begin{array}{c}\text { Water-level } \\
\text { altitude } \\
\text { (feet above } \\
\text { NGVD 29) }\end{array}$ & $\begin{array}{c}\text { Date of } \\
\text { measurement }\end{array}$ \\
\hline 01N01E04AAB1 & 344358 & 910015 & NRCS & 140 & 175 & 37.5 & 138 & 04/28/2012 \\
\hline 01N01E09CCC1 & 344215 & 910054 & NRCS & 140 & 182 & 36 & 146 & 04/19/2012 \\
\hline 01N02E11BAB1 & 344255 & 905208 & NRCS & 140 & 202 & 37 & 165 & 04/19/2012 \\
\hline 01N02E22CBA1 & 344056 & 905318 & NRCS & 140 & 200 & 30.5 & 170 & 04/19/2012 \\
\hline 01N02E33CBB1 & 343858 & 905434 & NRCS & 140 & 186 & 30.5 & 156 & 04/19/2012 \\
\hline 01N02E33CCB1 & 343851 & 905433 & NRCS & 140 & 185 & 15.5 & 170 & 04/19/2012 \\
\hline 02N01E21BAA1 & 344633 & 910005 & NRCS & 140 & 185 & 37.5 & 148 & 04/28/2012 \\
\hline 02N01E23BAA2 & 344632 & 905820 & USGS & 137 & 202 & 53.60 & 148 & 04/02/2012 \\
\hline 02N01W12BAA1 & 344828 & 910330 & USGS & 95 & 185 & 46.84 & 138 & 04/02/2012 \\
\hline 02N01W34DDC1 & 344410 & 910520 & NRCS & 140 & 180 & 57 & 123 & 04/28/2012 \\
\hline 02N02E08ADC1 & 344807 & 905339 & USGS & 120 & 201 & 46.35 & 155 & 04/02/2012 \\
\hline 02N02E36DDC1 & 344355 & 905020 & NRCS & 140 & 205 & 36 & 169 & 04/19/2012 \\
\hline 02N03E08AAD1 & 344811 & 904838 & USGS & 100 & 211 & 43.50 & 168 & 04/02/2012 \\
\hline 02N03E09DDD1 & 344723 & 904707 & NRCS & 120 & 220 & 49.6 & 170 & 04/28/2012 \\
\hline 03N01E32BCC1 & 344951 & 910150 & NRCS & 140 & 200 & 69.5 & 131 & 04/19/2012 \\
\hline 03N02E12CDC1 & 345239 & 905053 & NRCS & 140 & 210 & 45 & 165 & 04/19/2012 \\
\hline 03N02E13BBA1 & 345237 & 905107 & USGS & 65 & 212 & 50.22 & 162 & 04/02/2012 \\
\hline 03N02E21CBC1 & 345111 & 905428 & NRCS & 140 & 209 & 56.5 & 153 & 04/28/2012 \\
\hline 03N02E29DAD1 & 345014 & 905430 & USGS & 135 & 205 & 46.51 & 158 & 04/02/2012 \\
\hline 03N03E05CDD1 & 345327 & 904837 & NRCS & 110 & 204 & 40 & 164 & 04/19/2012 \\
\hline 03N03E18DAB1 & 345206 & 904919 & NRCS & 140 & 196 & 27 & 169 & 04/28/2012 \\
\hline 03N03E32CAB1 & 344933 & 904926 & USGS & 116 & 204 & 48.99 & 155 & 04/02/2012 \\
\hline 03N04E07CBB1 & 345245 & 904312 & NRCS & 140 & 200 & 16 & 184 & 04/28/2012 \\
\hline 03N05E14DDA1 & 345148 & 903203 & USGS & 120 & 193 & 11.57 & 181 & 04/02/2012 \\
\hline 03N05E26ADC1 & 345020 & 903215 & NRCS & 140 & 185 & 4.5 & 181 & 04/19/2012 \\
\hline
\end{tabular}


Appendix 1. Water levels measured in wells completed in the Mississippi River Valley alluvial aquifer in eastern Arkansas, 2012.Continued

[USGS, U.S. Geological Survey; NRCS, Natural Resources Conservation Service, ANRC, Arkansas Natural Resources Commission; --, no data; NGVD 29, National Geodetic Vertical Datum of 1929; Horizontal coordinate information is referenced to the North American Datum of 1983 (NAD 83)]

\begin{tabular}{|c|c|c|c|c|c|c|c|c|}
\hline Station name & $\begin{array}{c}\text { Latitude } \\
\text { (degrees, } \\
\text { minutes, } \\
\text { seconds) }\end{array}$ & $\begin{array}{c}\text { Longitude } \\
\text { (degrees, } \\
\text { minutes, } \\
\text { seconds) }\end{array}$ & $\begin{array}{l}\text { Source } \\
\text { of data }\end{array}$ & $\begin{array}{l}\text { Depth } \\
\text { of well } \\
\text { (feet) }\end{array}$ & $\begin{array}{c}\text { Land-surface } \\
\text { datum altitude } \\
\text { (feet above } \\
\text { NGVD 29) }\end{array}$ & $\begin{array}{c}\text { Depth to water } \\
\text { (feet below } \\
\text { land-surface } \\
\text { datum) }\end{array}$ & $\begin{array}{l}\text { Water-level } \\
\text { altitude } \\
\text { (feet above } \\
\text { NGVD 29) }\end{array}$ & $\begin{array}{c}\text { Date of } \\
\text { measurement }\end{array}$ \\
\hline \multicolumn{9}{|c|}{ Lincoln County } \\
\hline 07S06W03CCA2 & 340828 & 914114 & NRCS & 110 & 190 & 16 & 174 & 03/28/2012 \\
\hline 07S07W36CBD1 & 340411 & 914529 & NRCS & 123 & 183 & 42 & 141 & 03/27/2012 \\
\hline 08S04W08BBB2 & 340254 & 913101 & USGS & 65.2 & 171 & 20.13 & 151 & 03/13/2012 \\
\hline 08S04W29ABC1 & 340021 & 913044 & NRCS & 100 & 176 & 32 & 144 & 03/28/2012 \\
\hline 08S04W31CBA1 & 335901 & 913150 & USGS & 99 & 161.9 & 35.75 & 126 & 03/13/2012 \\
\hline 08S05W12AAD1 & 340246 & 913214 & NRCS & 83 & 165 & 32 & 133 & 03/28/2012 \\
\hline 09S05W14ABC1 & 335553 & 913439 & USGS & 98 & 172.5 & 41.95 & 131 & 03/12/2012 \\
\hline 09S05W17BCB1 & 335552 & 913820 & USGS & 97 & 171 & 40.96 & 130 & 03/12/2012 \\
\hline 09S05W19CCC1 & 335428 & 913941 & NRCS & 110 & 171 & 40 & 131 & 03/26/2012 \\
\hline 09S06W04BCD1 & 335821 & 914346 & USGS & 62.6 & 181 & 43.21 & 138 & 03/12/2012 \\
\hline 09S06W04BDD1 & 335759 & 914335 & NRCS & 100 & 178 & 45 & 133 & 03/26/2012 \\
\hline 10S05W05BCB1 & 335228 & 913833 & USGS & 127 & 172 & 28.23 & 144 & 03/12/2012 \\
\hline 10S05W06DCC1 & 335155 & 913908 & USGS & 65 & 175 & 29.82 & 145 & 03/12/2012 \\
\hline \multicolumn{9}{|c|}{ Lonoke County } \\
\hline 01S07W19DDB1 & 343609 & 914746 & USGS & 151.9 & 206 & 86.82 & 119 & 03/20/2012 \\
\hline 01S08W24CDD1 & 343606 & 914912 & USGS & 127 & 210 & 83.64 & 126 & 03/20/2012 \\
\hline 01S09W02DDD1 & 343857 & 915624 & NRCS & -- & 230 & 83 & 147 & 03/29/2012 \\
\hline 01S09W36CCC1 & 343435 & 915619 & USGS & 95 & 220 & 62.94 & 157 & 03/19/2012 \\
\hline 01S10W01ACB1 & 343927 & 920215 & USGS & -- & 236 & 43.47 & 193 & 03/19/2012 \\
\hline 01S10W11CAB1 & 343841 & 920337 & USGS & 105.5 & 235 & 29.35 & 206 & 03/19/2012 \\
\hline 02N07W07DAA1 & 344845 & 914707 & NRCS & -- & 232 & 138 & 94 & 03/29/2012 \\
\hline 02N07W16BAB1 & 344815 & 914540 & USGS & 184 & 240 & 144.93 & 95 & 03/20/2012 \\
\hline 02N08W16ABC1 & 344806 & 915114 & USGS & 170 & 230 & 126.87 & 103 & 03/20/2012 \\
\hline 02N08W23CAB1 & 344659 & 915118 & NRCS & -- & 229 & 135 & 94 & 03/29/2012 \\
\hline 02N08W27DCC1 & 344543 & 915106 & ANRC & 176.6 & 230 & 131.96 & 98 & 04/10/2012 \\
\hline 02N10W15ACC1 & 344807 & 920353 & NRCS & 135 & 241 & 28 & 213 & 03/29/2012 \\
\hline 02N10W23BCA1 & 344725 & 920322 & USGS & -- & 242 & 11.46 & 231 & 03/20/2012 \\
\hline
\end{tabular}


Appendix 1. Water levels measured in wells completed in the Mississippi River Valley alluvial aquifer in eastern Arkansas, 2012.Continued

[USGS, U.S. Geological Survey; NRCS, Natural Resources Conservation Service, ANRC, Arkansas Natural Resources Commission; --, no data; NGVD 29, National Geodetic Vertical Datum of 1929; Horizontal coordinate information is referenced to the North American Datum of 1983 (NAD 83)]

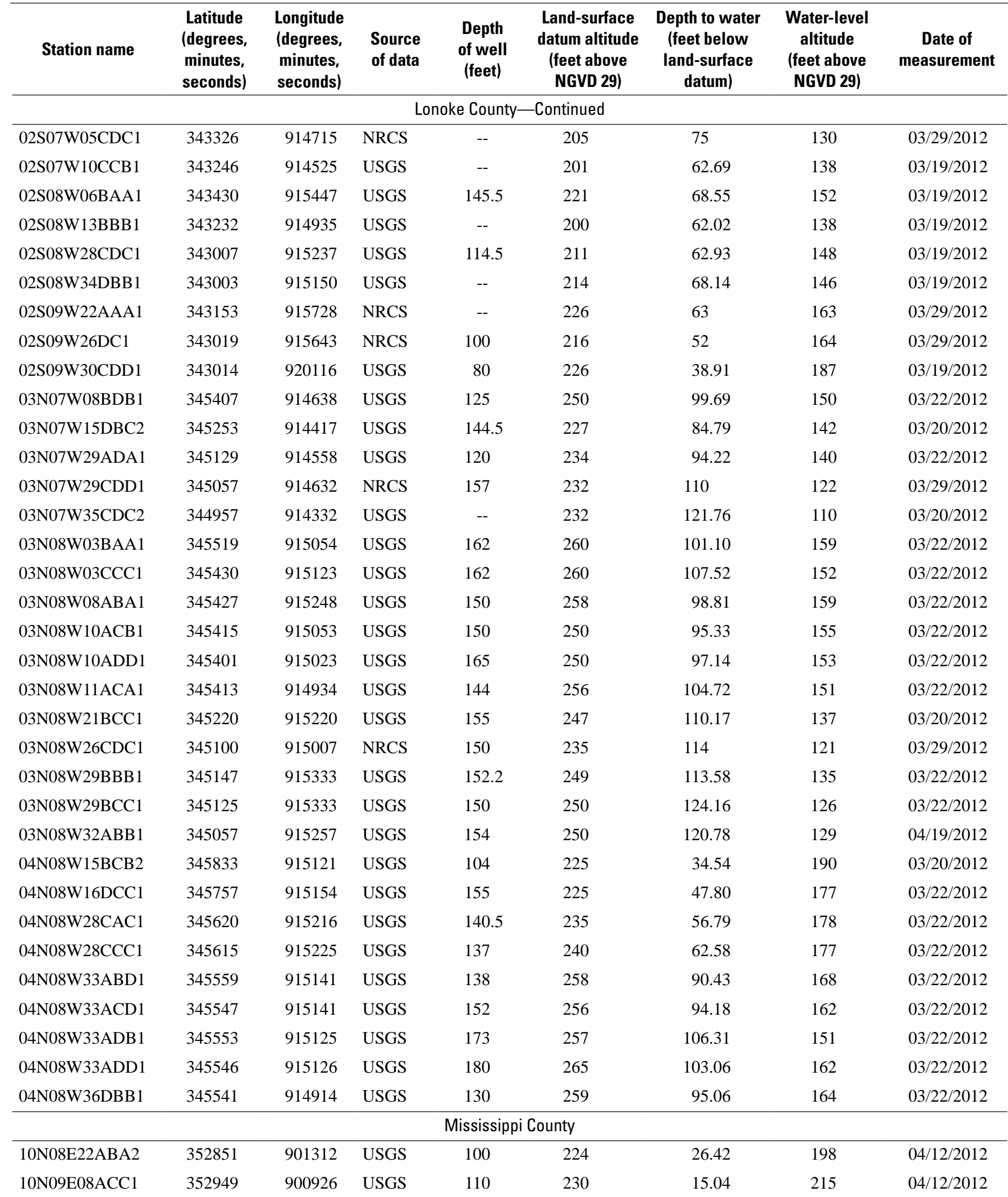


Appendix 1. Water levels measured in wells completed in the Mississippi River Valley alluvial aquifer in eastern Arkansas, 2012.Continued

[USGS, U.S. Geological Survey; NRCS, Natural Resources Conservation Service, ANRC, Arkansas Natural Resources Commission; --, no data; NGVD 29, National Geodetic Vertical Datum of 1929; Horizontal coordinate information is referenced to the North American Datum of 1983 (NAD 83)]

\begin{tabular}{|c|c|c|c|c|c|c|c|c|}
\hline Station name & $\begin{array}{l}\text { Latitude } \\
\text { (degrees, } \\
\text { minutes, } \\
\text { seconds) }\end{array}$ & $\begin{array}{l}\text { Longitude } \\
\text { (degrees, } \\
\text { minutes, } \\
\text { seconds) }\end{array}$ & $\begin{array}{l}\text { Source } \\
\text { of data }\end{array}$ & $\begin{array}{c}\text { Depth } \\
\text { of well } \\
\text { (feet) }\end{array}$ & $\begin{array}{l}\text { Land-surface } \\
\text { datum altitude } \\
\text { (feet above } \\
\text { NGVD 29) }\end{array}$ & $\begin{array}{c}\text { Depth to water } \\
\text { (feet below } \\
\text { land-surface } \\
\text { datum) }\end{array}$ & $\begin{array}{c}\text { Water-level } \\
\text { altitude } \\
\text { (feet above } \\
\text { NGVD 29) }\end{array}$ & $\begin{array}{c}\text { Date of } \\
\text { measurement }\end{array}$ \\
\hline \multicolumn{9}{|c|}{ Mississippi County-Continued } \\
\hline 11N09E34BBB1 & 353218 & 900715 & USGS & 94 & 235 & 16.99 & 218 & 04/12/2012 \\
\hline 12N08E08BCB1 & 354047 & 901559 & USGS & 120 & 225 & 9.64 & 215 & 04/12/2012 \\
\hline 14N08E12DAB1 & 355104 & 901052 & USGS & -- & 235 & 6.12 & 229 & 04/12/2012 \\
\hline 14N10E18ABC1 & 355022 & 900345 & USGS & 101 & 236 & 12.96 & 223 & 04/12/2012 \\
\hline 15N08E08DBC2 & 355605 & 901526 & USGS & 120 & 236 & 11.24 & 225 & 04/12/2012 \\
\hline 16N10E28BBD1 & 355906 & 900156 & USGS & 120 & 238 & 12.78 & 225 & 04/12/2012 \\
\hline 01N02W12CBC1 & 344242 & 911032 & USGS & 110 & 182 & 42.76 & 139 & 03/29/2012 \\
\hline 01N03W23BAC1 & 344124 & 911743 & NRCS & 100 & 170 & 9.5 & 161 & 04/24/2012 \\
\hline 01N03W24BBB1 & 344135 & 911651 & USGS & 125 & 185 & 26.08 & 159 & 03/29/2012 \\
\hline 01N04W33BBB2 & 343960 & 912649 & USGS & -- & 218 & 104.94 & 113 & 03/29/2012 \\
\hline 01S01W13CDD1 & 343611 & 910341 & USGS & 135 & 178 & 21.33 & 157 & 03/29/2012 \\
\hline 01S01W16DB & 343615 & 910632 & NRCS & 100 & 175 & 19 & 156 & 04/24/2012 \\
\hline 01S01W18DCD1 & 343618 & 910849 & USGS & 110 & 178 & 23.96 & 154 & 03/29/2012 \\
\hline 01S02W20BBB1 & 343613 & 911456 & USGS & 100 & 170 & 9.68 & 160 & 03/29/2012 \\
\hline 02S02W11DAC1 & 343209 & 911101 & USGS & 110 & 164 & 6.80 & 157 & 03/28/2012 \\
\hline 03N01W06DBA1 & 345411 & 910822 & USGS & 120 & 191 & 45.81 & 145 & 03/29/2012 \\
\hline 03N01W20ABA1 & 345201 & 910723 & USGS & -- & 189 & 50.06 & 139 & 03/29/2012 \\
\hline 03N02W31ADC1 & 344958 & 911447 & USGS & 95 & 190 & 38.27 & 152 & 03/29/2012 \\
\hline 03N03W36AAA1 & 345027 & 911547 & USGS & 120 & 176 & 18.98 & 157 & 03/29/2012 \\
\hline 04N02W01BCC1 & 345929 & 911004 & NRCS & 100 & 175 & 39.5 & 136 & $04 / 24 / 2012$ \\
\hline 04N02W05BBB1 & 345957 & 911311 & NRCS & 100 & 188 & 15 & 173 & 04/24/2012 \\
\hline 04N02W27CDD3 & 345540 & 911150 & USGS & 181 & 200 & 45.61 & 154 & 03/29/2012 \\
\hline 04N02W28DDD3 & 345535 & 911221 & USGS & 137 & 192 & 32.87 & 159 & 03/29/2012 \\
\hline 04N02W30BBB1 & 345628 & 911525 & USGS & 119 & 185.16 & 12.76 & 172 & 03/29/2012 \\
\hline \multicolumn{9}{|c|}{ Phillips County } \\
\hline 01S01E20DDB1 & 343529 & 910058 & NRCS & 114 & 185 & 27 & 158 & $03 / 12 / 2012$ \\
\hline 01S02E09CBB1 & 343719 & 905434 & USGS & 110 & 185 & 13.19 & 172 & 03/28/2012 \\
\hline
\end{tabular}


Appendix 1. Water levels measured in wells completed in the Mississippi River Valley alluvial aquifer in eastern Arkansas, 2012.Continued

[USGS, U.S. Geological Survey; NRCS, Natural Resources Conservation Service, ANRC, Arkansas Natural Resources Commission; --, no data; NGVD 29, National Geodetic Vertical Datum of 1929; Horizontal coordinate information is referenced to the North American Datum of 1983 (NAD 83)]

\begin{tabular}{|c|c|c|c|c|c|c|c|c|}
\hline Station name & $\begin{array}{l}\text { Latitude } \\
\text { (degrees, } \\
\text { minutes, } \\
\text { seconds) }\end{array}$ & $\begin{array}{l}\text { Longitude } \\
\text { (degrees, } \\
\text { minutes, } \\
\text { seconds) }\end{array}$ & $\begin{array}{l}\text { Source } \\
\text { of data }\end{array}$ & $\begin{array}{l}\text { Depth } \\
\text { of well } \\
\text { (feet) }\end{array}$ & $\begin{array}{l}\text { Land-surface } \\
\text { datum altitude } \\
\text { (feet above } \\
\text { NGVD 29) }\end{array}$ & $\begin{array}{l}\text { Depth to water } \\
\text { (feet below } \\
\text { land-surface } \\
\text { datum) }\end{array}$ & $\begin{array}{c}\text { Water-level } \\
\text { altitude } \\
\text { (feet above } \\
\text { NGVD 29) }\end{array}$ & $\begin{array}{c}\text { Date of } \\
\text { measurement }\end{array}$ \\
\hline 01S02E32BCC1 & 343350 & 905526 & NRCS & 120 & 200 & 50.8 & 149 & $03 / 12 / 2012$ \\
\hline 01S03E02ADD1 & 343814 & 904511 & NRCS & 120 & 200 & 19 & 181 & 03/13/2012 \\
\hline 01S04E05DCD1 & 343802 & 904151 & USGS & 120 & 230 & 47.70 & 182 & 03/28/2012 \\
\hline 02S01E28CCB1 & 342916 & 910058 & USGS & 108 & 174 & 17.37 & 157 & 03/28/2012 \\
\hline 02S02E29DDD1 & 342901 & 905444 & NRCS & 125 & 180 & 27 & 153 & 03/13/2012 \\
\hline 02S02E33ACC1 & 342824 & 905412 & NRCS & 120 & 177 & 25 & 152 & 03/13/2012 \\
\hline 03S03E04DAA1 & 342735 & 904710 & USGS & 36 & 171 & 19.53 & 151 & 03/28/2012 \\
\hline 03S04E02CAA1 & 342732 & 903918 & USGS & 120 & 176 & 10.90 & 165 & 03/28/2012 \\
\hline 04S01E01AAD1 & 342238 & 905700 & NRCS & 120 & 156 & 14 & 142 & 03/13/2012 \\
\hline 04S01E14CDD1 & 342014 & 905837 & NRCS & 120 & 155 & 13 & 142 & 03/13/2012 \\
\hline 04S01E23CCA1 & 341931 & 905853 & USGS & & 156 & 13.11 & 143 & 03/28/2012 \\
\hline 04S01E29CDC1 & 341844 & 910148 & NRCS & 120 & 150 & 8.5 & 142 & 03/13/2012 \\
\hline 05S02E18BDA1 & 341535 & 905628 & USGS & 130 & 156 & 15.32 & 141 & 03/28/2012 \\
\hline \multicolumn{9}{|c|}{ Poinsett County } \\
\hline 10N02E15CAA1 & 352940 & 905209 & NRCS & 160 & 237 & 112 & 125 & 03/20/2012 \\
\hline 10N02E20BAB1 & 352906 & 905418 & NRCS & 155 & 237 & 111 & 126 & 03/20/2012 \\
\hline 10N02E34BBB1 & 352726 & 905231 & USGS & 155.9 & 236 & 104.57 & 131 & 05/01/2012 \\
\hline 10N03E13BCB1 & 352958 & 904352 & NRCS & 155 & 275 & 144 & 131 & 03/20/2012 \\
\hline 10N03E14DAB1 & 352947 & 904405 & USGS & -- & 263 & 121.34 & 142 & 05/01/2012 \\
\hline 10N03E19BCB1 & 352905 & 904907 & NRCS & -- & 239 & 110 & 129 & 03/20/2012 \\
\hline 10N03E26BBD1 & 352816 & 904449 & NRCS & 140 & 257 & 120 & 137 & 03/20/2012 \\
\hline 10N03E35CDD1 & 352656 & 904436 & USGS & -- & 275 & 127.54 & 147 & 05/01/2012 \\
\hline 10N04E35BBA1 & 352745 & 903831 & NRCS & 100 & 212 & 15 & 197 & 03/19/2012 \\
\hline 10N05E15BDD1 & 352937 & 903253 & USGS & -- & 207 & 12.84 & 194 & $04 / 12 / 2012$ \\
\hline 10N07E28CBB1 & 352733 & 902128 & NRCS & 105 & 217 & 30 & 187 & 03/20/2012 \\
\hline 11N01E17DDC1 & 353437 & 910015 & NRCS & 100 & 232 & 88 & 144 & 03/20/2012 \\
\hline 11N01E17DDD1 & 353437 & 910013 & USGS & 100 & 230 & 83.30 & 147 & 04/26/2012 \\
\hline
\end{tabular}


Appendix 1. Water levels measured in wells completed in the Mississippi River Valley alluvial aquifer in eastern Arkansas, 2012.Continued

[USGS, U.S. Geological Survey; NRCS, Natural Resources Conservation Service, ANRC, Arkansas Natural Resources Commission; --, no data; NGVD 29, National Geodetic Vertical Datum of 1929; Horizontal coordinate information is referenced to the North American Datum of 1983 (NAD 83)]

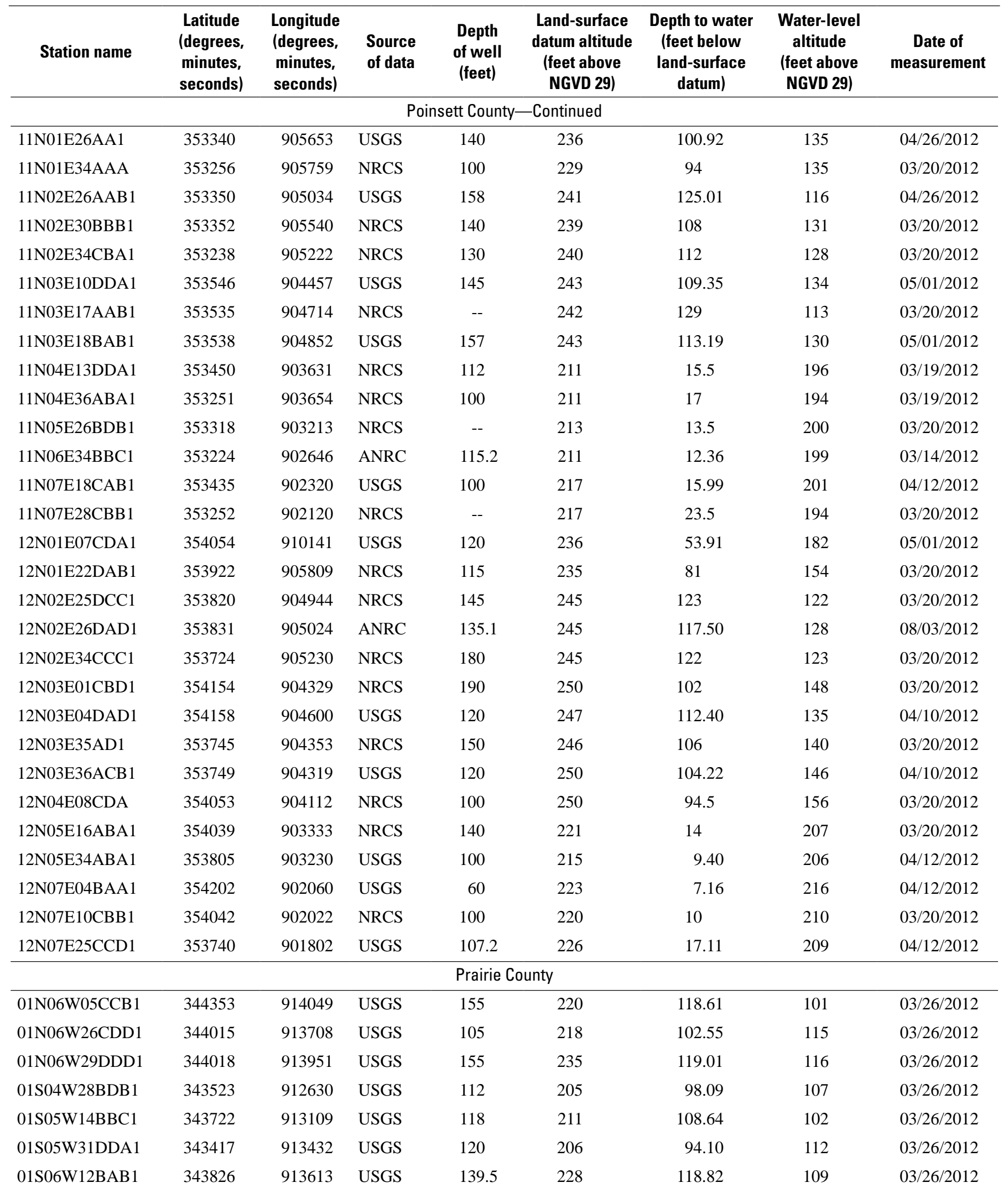


Appendix 1. Water levels measured in wells completed in the Mississippi River Valley alluvial aquifer in eastern Arkansas, 2012.Continued

[USGS, U.S. Geological Survey; NRCS, Natural Resources Conservation Service, ANRC, Arkansas Natural Resources Commission; --, no data; NGVD 29, National Geodetic Vertical Datum of 1929; Horizontal coordinate information is referenced to the North American Datum of 1983 (NAD 83)]

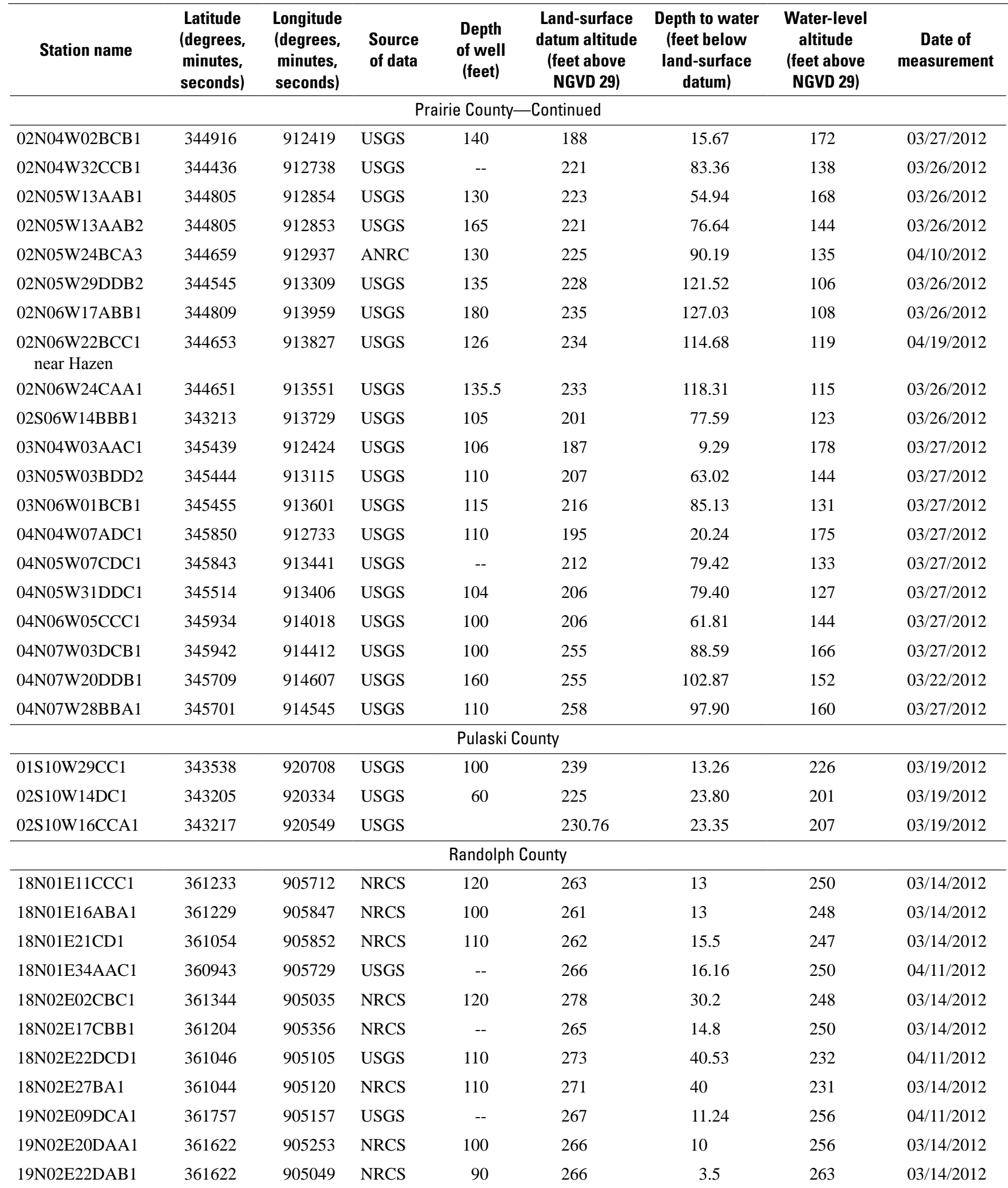


Appendix 1. Water levels measured in wells completed in the Mississippi River Valley alluvial aquifer in eastern Arkansas, 2012.Continued

[USGS, U.S. Geological Survey; NRCS, Natural Resources Conservation Service, ANRC, Arkansas Natural Resources Commission; --, no data; NGVD 29, National Geodetic Vertical Datum of 1929; Horizontal coordinate information is referenced to the North American Datum of 1983 (NAD 83)]

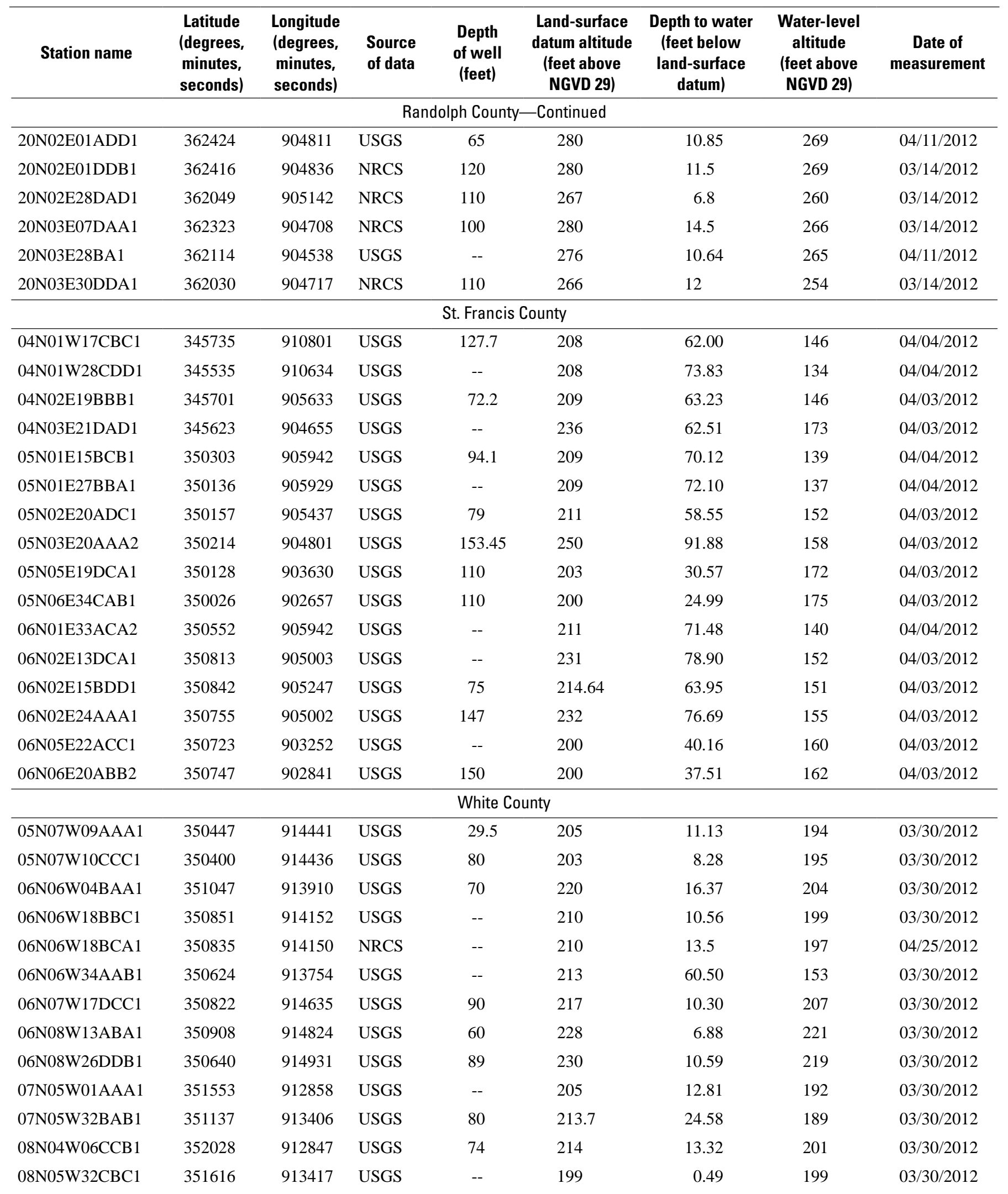


Appendix 1. Water levels measured in wells completed in the Mississippi River Valley alluvial aquifer in eastern Arkansas, 2012.— Continued

[USGS, U.S. Geological Survey; NRCS, Natural Resources Conservation Service, ANRC, Arkansas Natural Resources Commission; --, no data; NGVD 29, National Geodetic Vertical Datum of 1929; Horizontal coordinate information is referenced to the North American Datum of 1983 (NAD 83)]

\begin{tabular}{|c|c|c|c|c|c|c|c|c|}
\hline Station name & $\begin{array}{l}\text { Latitude } \\
\text { (degrees, } \\
\text { minutes, } \\
\text { seconds) }\end{array}$ & $\begin{array}{l}\text { Longitude } \\
\text { (degrees, } \\
\text { minutes, } \\
\text { seconds) }\end{array}$ & $\begin{array}{l}\text { Source } \\
\text { of data }\end{array}$ & $\begin{array}{l}\text { Depth } \\
\text { of well } \\
\text { (feet) }\end{array}$ & $\begin{array}{l}\text { Land-surface } \\
\text { datum altitude } \\
\text { (feet above } \\
\text { NGVD 29) }\end{array}$ & $\begin{array}{l}\text { Depth to water } \\
\text { (feet below } \\
\text { land-surface } \\
\text { datum) }\end{array}$ & $\begin{array}{c}\text { Water-level } \\
\text { altitude } \\
\text { (feet above } \\
\text { NGVD 29) }\end{array}$ & $\begin{array}{c}\text { Date of } \\
\text { measurement }\end{array}$ \\
\hline 04N03W03AB1 & 350021 & 911820 & USGS & 100 & 185 & 11.36 & 174 & 04/04/2012 \\
\hline 05N01W13CDC1 & 350244 & 910331 & NRCS & 135 & 210 & 79 & 131 & 04/10/2012 \\
\hline 05N02W20DCB1 & 350208 & 911356 & USGS & -- & 192 & 12.88 & 179 & 04/04/2012 \\
\hline 05N03W25DDB1 & 350133 & 911531 & NRCS & 120 & 190 & 11.7 & 178 & 04/10/2012 \\
\hline 05N04W12DBA1 & 350427 & 912211 & USGS & 92 & 186 & 4.35 & 182 & 04/04/2012 \\
\hline 06N01W06BAB1 & 351048 & 910835 & USGS & -- & 202 & 33.21 & 169 & 04/05/2012 \\
\hline 06N02W19AAA1 & 350802 & 911419 & NRCS & 130 & 225 & 47.5 & 178 & 04/10/2012 \\
\hline 06N03W15BAB1 & 350903 & 911807 & USGS & 111 & 188.79 & 4.54 & 184 & 04/04/2012 \\
\hline 06N03W31BCB1 & 350623 & 912144 & USGS & -- & 185 & 2.73 & 182 & 04/04/2012 \\
\hline 06N04W22BDA1 & 350807 & 912428 & NRCS & 120 & 186 & 2.0 & 184 & 04/10/2012 \\
\hline 07N01W04ABB1 & 351555 & 910607 & USGS & 120 & 226 & 61.44 & 165 & 04/04/2012 \\
\hline 07N03W19AAA1 & 351335 & 912025 & USGS & 100 & 202.59 & 8.49 & 194 & 04/05/2012 \\
\hline 07N03W31BBA1 & 351152 & 912103 & NRCS & 120 & 195 & 8.0 & 187 & 04/10/2012 \\
\hline 08N01W06DDD1 & 352028 & 910747 & USGS & -- & 218 & 43.49 & 175 & 04/05/2012 \\
\hline 09N03W32ACA1 & 352205 & 911936 & NRCS & 120 & 217 & 15.0 & 202 & 04/10/2012 \\
\hline
\end{tabular}




\section{Water Levels and Water Quality in the Mississippi River Valley Alluvial Aquifer in Eastern Arkansas, 2012}

Appendix 2. Difference in water levels measured from 2008 to 2012 in the Mississippi River Valley alluvial aquifer in eastern Arkansas.

[Horizontal coordinate information is referenced to the North American Datum of 1983 (NAD 83)]

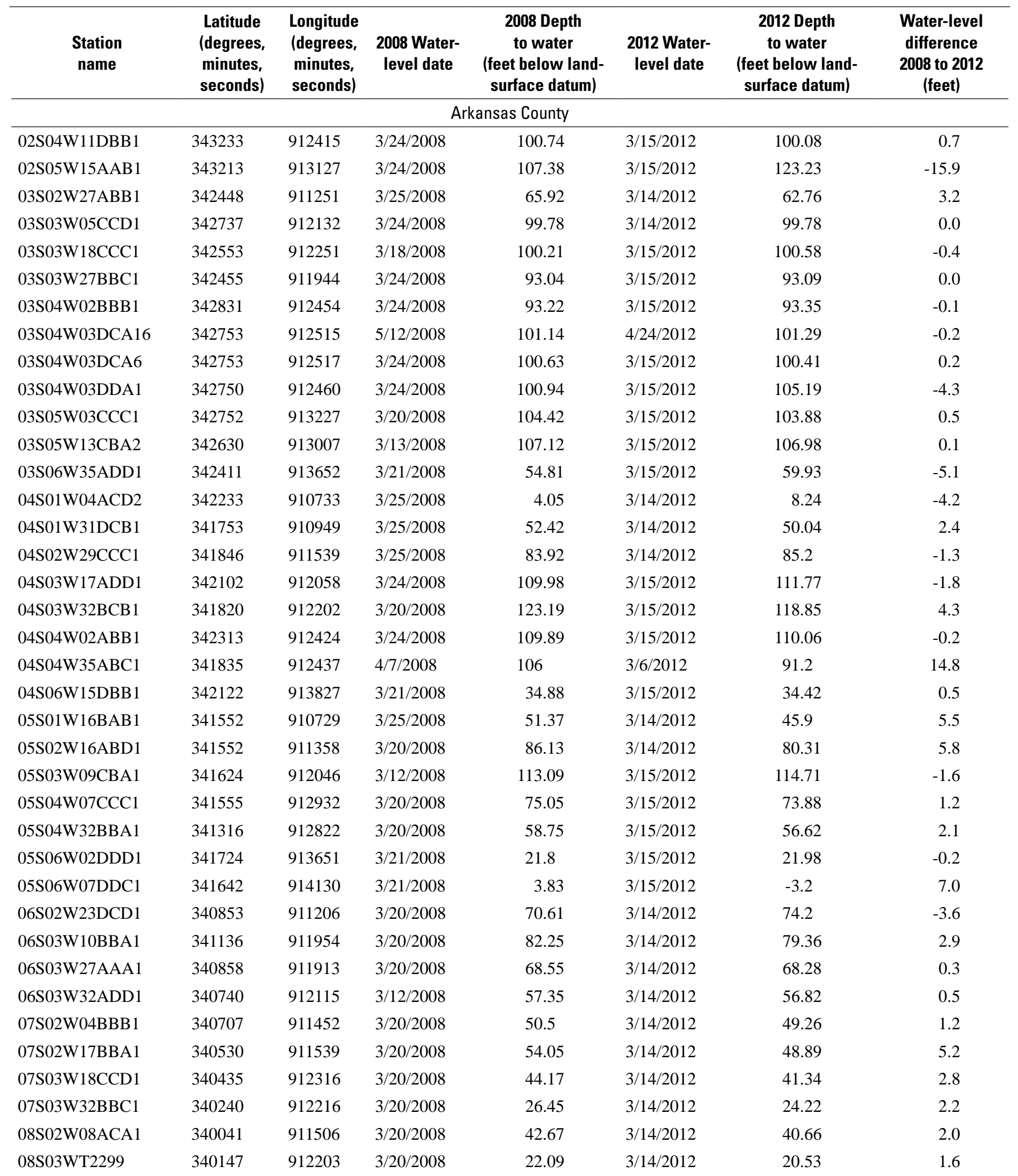


Appendix 2. Difference in water levels measured from 2008 to 2012 in the Mississippi River Valley alluvial aquifer in eastern Arkansas.-Continued

[Horizontal coordinate information is referenced to the North American Datum of 1983 (NAD 83)]

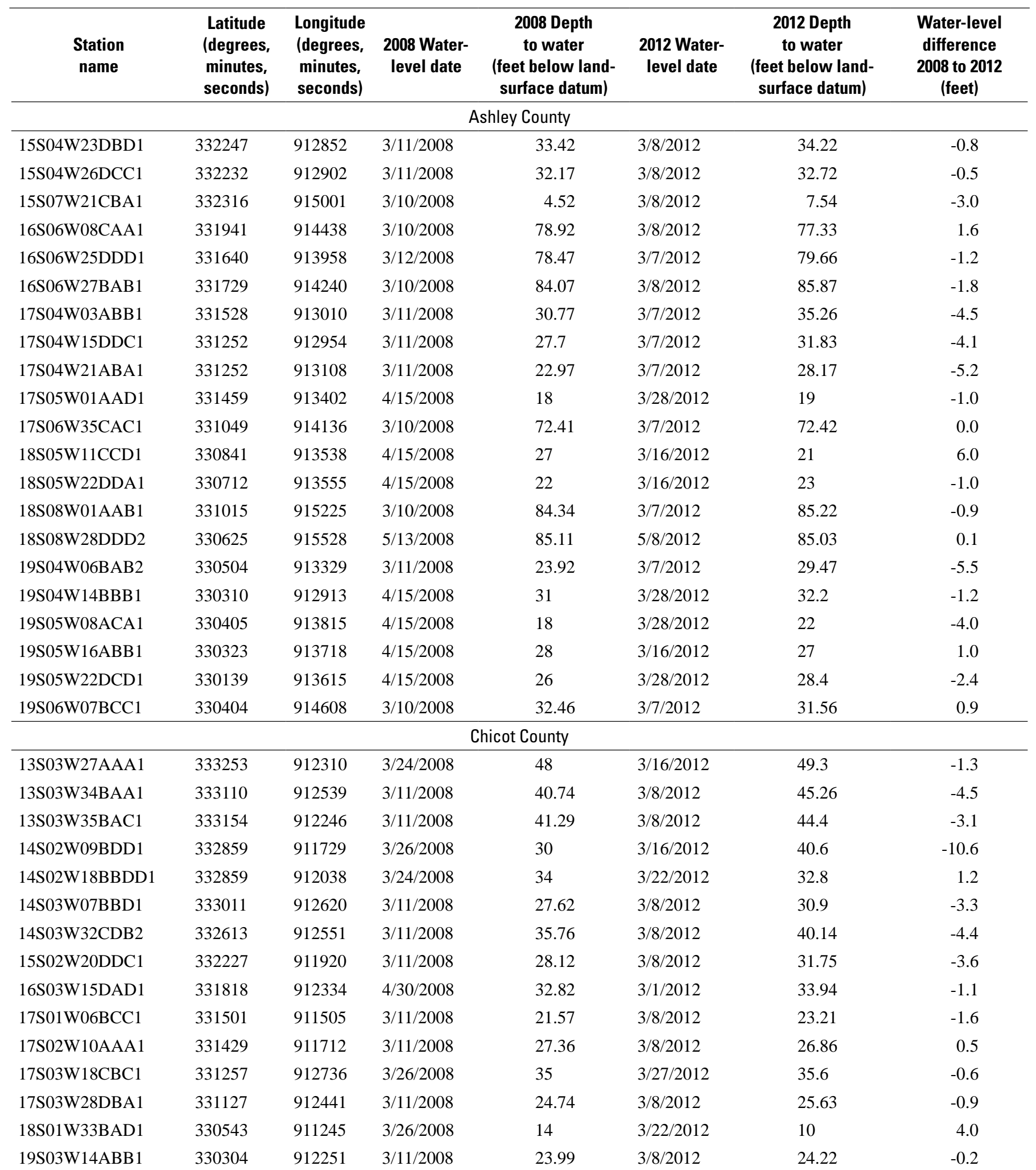


Appendix 2. Difference in water levels measured from 2008 to 2012 in the Mississippi River Valley alluvial aquifer in eastern Arkansas.-Continued

[Horizontal coordinate information is referenced to the North American Datum of 1983 (NAD 83)]

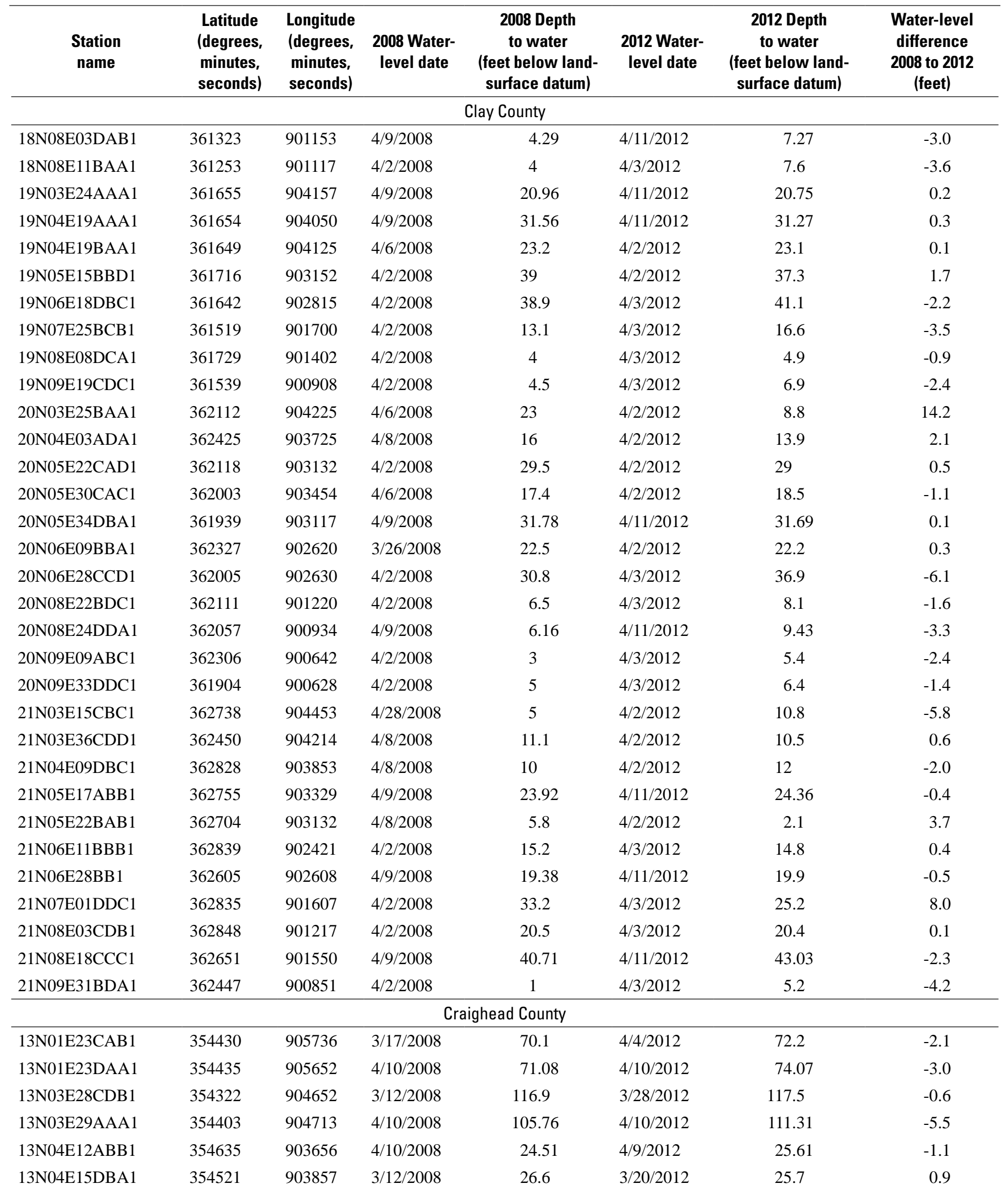


Appendix 2. Difference in water levels measured from 2008 to 2012 in the Mississippi River Valley alluvial aquifer in eastern Arkansas.-Continued

[Horizontal coordinate information is referenced to the North American Datum of 1983 (NAD 83)]

\begin{tabular}{|c|c|c|c|c|c|c|c|}
\hline $\begin{array}{l}\text { Station } \\
\text { name }\end{array}$ & $\begin{array}{c}\text { Latitude } \\
\text { (degrees, } \\
\text { minutes, } \\
\text { seconds) }\end{array}$ & $\begin{array}{l}\text { Longitude } \\
\text { (degrees, } \\
\text { minutes, } \\
\text { seconds) }\end{array}$ & $\begin{array}{l}2008 \text { Water- } \\
\text { level date }\end{array}$ & $\begin{array}{c}2008 \text { Depth } \\
\text { to water } \\
\text { (feet below land- } \\
\text { surface datum) }\end{array}$ & $\begin{array}{c}2012 \text { Water- } \\
\text { level date }\end{array}$ & $\begin{array}{c}2012 \text { Depth } \\
\text { to water } \\
\text { (feet below land- } \\
\text { surface datum) }\end{array}$ & $\begin{array}{c}\text { Water-level } \\
\text { difference } \\
2008 \text { to } 2012 \\
\text { (feet) }\end{array}$ \\
\hline \multicolumn{8}{|c|}{ Craighead County-Continued } \\
\hline 13N04E26BCC1 & 354340 & 903829 & $3 / 12 / 2008$ & 26.6 & 3/20/2012 & 27.5 & -0.9 \\
\hline 13N05E02CCC1 & 354648 & 903202 & $3 / 12 / 2008$ & 13.5 & 3/20/2012 & 15 & -1.5 \\
\hline 13N06E21AAA1 & 354450 & 902701 & $3 / 12 / 2008$ & 8.5 & 3/20/2012 & 9 & -0.5 \\
\hline 13N07E02CAB1 & 354642 & 901901 & $3 / 12 / 2008$ & 10.5 & $3 / 20 / 2012$ & 10 & 0.5 \\
\hline 13N07E05ABB1 & 354716 & 902158 & $3 / 12 / 2008$ & 4.4 & 3/20/2012 & 7.3 & -2.9 \\
\hline 13N07E20BBA1 & 354440 & 902216 & $4 / 10 / 2008$ & 1.95 & $4 / 10 / 2012$ & 4.92 & -3.0 \\
\hline 14N01E31DCA1 & 354817 & 910121 & $3 / 17 / 2008$ & 61.9 & $4 / 4 / 2012$ & 66.5 & -4.6 \\
\hline 14N02E18BDD1 & 355041 & 905419 & $4 / 10 / 2008$ & 53.57 & 4/10/2012 & 60.4 & -6.8 \\
\hline 14N02E22AAA1 & 355007 & 905129 & $3 / 17 / 2008$ & 78 & 3/28/2012 & 79.5 & -1.5 \\
\hline 14N02E27AAA1 & 354916 & 905125 & 4/9/2008 & 80.46 & $5 / 2 / 2012$ & 84.64 & -4.2 \\
\hline 14N05E25ABB1 & 354921 & 903025 & $4 / 10 / 2008$ & 18.58 & 4/10/2012 & 19.61 & -1.0 \\
\hline 14N06E06BAA1 & 355234 & 902934 & $3 / 12 / 2008$ & 21.5 & 3/20/2012 & 21 & 0.5 \\
\hline 14N06E27AAB1 & 354911 & 902559 & 4/10/2008 & -0.25 & 4/10/2012 & 2.81 & -3.1 \\
\hline 14N07E14DDC1 & 354956 & 901831 & $3 / 12 / 2008$ & 13.1 & 3/20/2012 & 14.5 & -1.4 \\
\hline 14N07E26DBB1 & 354834 & 901843 & $4 / 10 / 2008$ & 2.68 & 4/10/2012 & 7.05 & -4.4 \\
\hline 04N07E21AAD1 & 345644 & 902121 & $4 / 3 / 2008$ & 10.1 & 4/9/2012 & 9.87 & 0.2 \\
\hline 05N07E28CBA1 & 350121 & 902140 & $4 / 3 / 2008$ & 17.08 & 4/9/2012 & 16.06 & 1.0 \\
\hline 05N07E34BAB1 & 350059 & 902030 & $4 / 3 / 2008$ & 16.27 & 4/9/2012 & 14.36 & 1.9 \\
\hline 05N08E11CCD2 & 350345 & 901308 & 4/3/2008 & 25.27 & 4/9/2012 & 24.91 & 0.4 \\
\hline 07N07E05DAD1 & 351504 & 902129 & $4 / 3 / 2008$ & 31.39 & 4/9/2012 & 30.98 & 0.4 \\
\hline 07N07E31CCC1 & 351042 & 902359 & $4 / 3 / 2008$ & 36.48 & 4/9/2012 & 36.53 & -0.1 \\
\hline 07N09E05CDD1 & 351453 & 900934 & $4 / 3 / 2008$ & 14.83 & 4/9/2012 & 9.46 & 5.4 \\
\hline 08N07E13CCC2 & 351828 & 901812 & $4 / 3 / 2008$ & 31.43 & 4/9/2012 & 31.13 & 0.3 \\
\hline 08N07E14DAA2 & 351854 & 901833 & $4 / 3 / 2008$ & 31.82 & 4/9/2012 & 32.62 & -0.8 \\
\hline 08N07E35BBC1 & 351630 & 901933 & $4 / 7 / 2008$ & 32.58 & $3 / 14 / 2012$ & 32.56 & 0.0 \\
\hline 09N07E10DDA1 & 352448 & 901925 & $4 / 3 / 2008$ & 29.29 & 4/9/2012 & 28.84 & 0.4 \\
\hline 09N07E31BAB1 & 352160 & 902327 & 4/3/2008 & 34.06 & 4/9/2012 & 33.2 & 0.9 \\
\hline
\end{tabular}


Appendix 2. Difference in water levels measured from 2008 to 2012 in the Mississippi River Valley alluvial aquifer in eastern Arkansas.-Continued

[Horizontal coordinate information is referenced to the North American Datum of 1983 (NAD 83)]

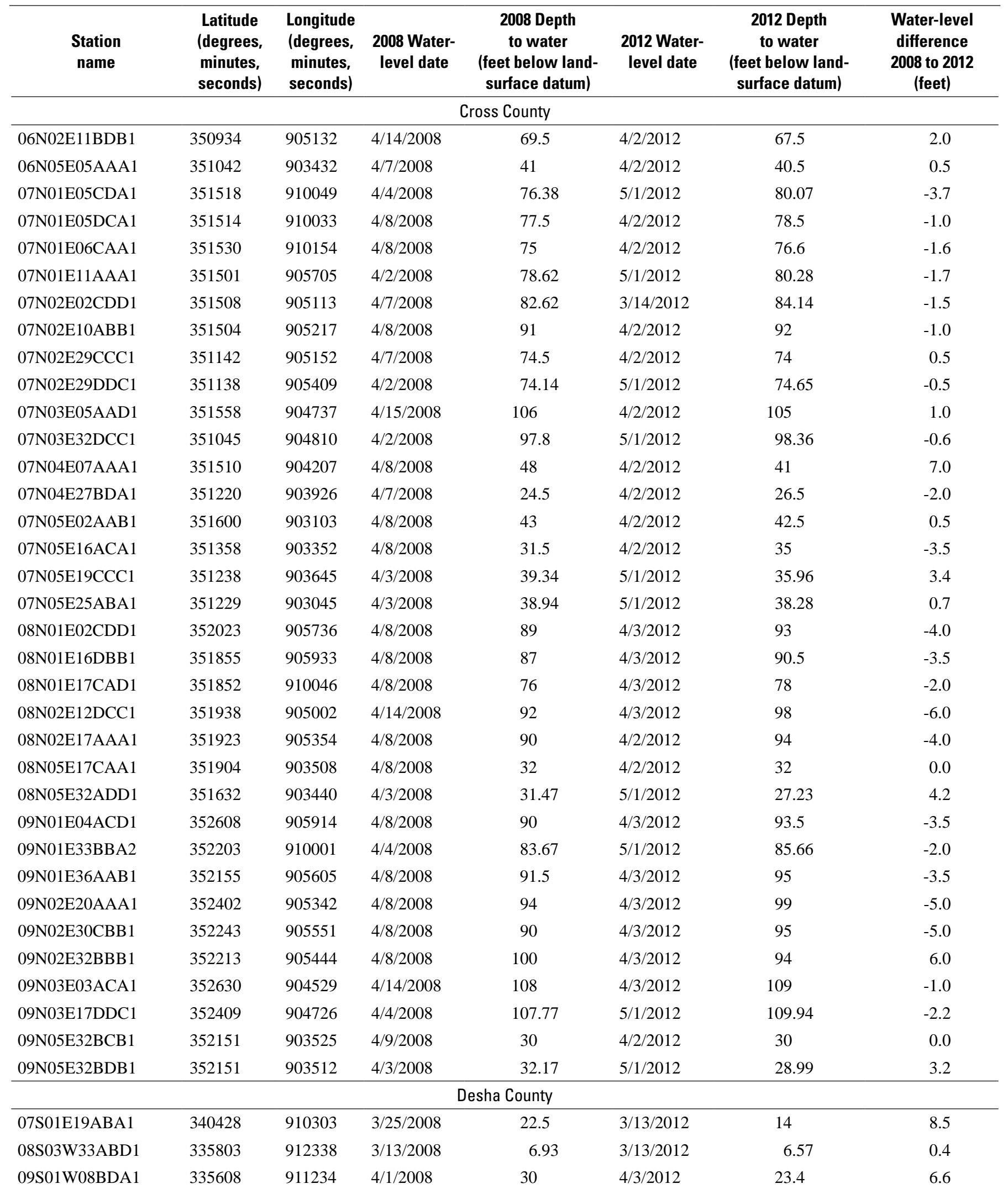


Appendix 2. Difference in water levels measured from 2008 to 2012 in the Mississippi River Valley alluvial aquifer in eastern Arkansas.-Continued

[Horizontal coordinate information is referenced to the North American Datum of 1983 (NAD 83)]

\begin{tabular}{|c|c|c|c|c|c|c|c|}
\hline $\begin{array}{l}\text { Station } \\
\text { name }\end{array}$ & $\begin{array}{c}\text { Latitude } \\
\text { (degrees, } \\
\text { minutes, } \\
\text { seconds) }\end{array}$ & $\begin{array}{c}\text { Longitude } \\
\text { (degrees, } \\
\text { minutes, } \\
\text { seconds) }\end{array}$ & $\begin{array}{c}2008 \text { Water- } \\
\text { level date }\end{array}$ & $\begin{array}{c}2008 \text { Depth } \\
\text { to water } \\
\text { (feet below land- } \\
\text { surface datum) }\end{array}$ & $\begin{array}{l}2012 \text { Water- } \\
\text { level date }\end{array}$ & $\begin{array}{c}2012 \text { Depth } \\
\text { to water } \\
\text { (feet below land- } \\
\text { surface datum) }\end{array}$ & $\begin{array}{c}\text { Water-level } \\
\text { difference } \\
2008 \text { to } 2012 \\
\text { (feet) }\end{array}$ \\
\hline \multicolumn{8}{|c|}{ Desha County-Continued } \\
\hline 09S01W15CBB1 & 335501 & 911055 & $4 / 1 / 2008$ & 39 & 4/3/2012 & 38.6 & 0.4 \\
\hline 09S02W26DDC1 & 335257 & 911530 & $5 / 13 / 2008$ & 31.68 & $4 / 24 / 2012$ & 32.31 & -0.6 \\
\hline 09S03W13BAB1 & 335500 & 911922 & $4 / 1 / 2008$ & 35 & 4/3/2012 & 36.5 & -1.5 \\
\hline 09S03W17DCB1 & 335448 & 912457 & $3 / 13 / 2008$ & 33.68 & 3/13/2012 & 37.38 & -3.7 \\
\hline 09S04W06BCA1 & 335756 & 913243 & $3 / 13 / 2008$ & 36.43 & 3/13/2012 & 37.66 & -1.2 \\
\hline 09S04W06CBB1 & 335629 & 913257 & $3 / 12 / 2008$ & 39 & 3/29/2012 & 44 & -5.0 \\
\hline 10S03W26CAA1 & 334806 & 912145 & $3 / 12 / 2008$ & 47.43 & 3/13/2012 & 48.71 & -1.3 \\
\hline 10S04W03BAB1 & 335209 & 912948 & 3/13/2008 & 36.86 & 3/13/2012 & 39.55 & -2.7 \\
\hline 10S04W11DDA1 & 335031 & 912802 & $3 / 13 / 2008$ & 33.33 & 3/13/2012 & 35.52 & -2.2 \\
\hline 11S02W15ADD1 & 334446 & 911635 & $4 / 1 / 2008$ & 36 & 4/3/2012 & 35.9 & 0.1 \\
\hline 11S03W16CBA1 & 334439 & 912433 & $4 / 1 / 2008$ & 36 & $4 / 3 / 2012$ & 36 & 0.0 \\
\hline 11S03W31BBA1 & 334228 & 912651 & $3 / 12 / 2008$ & 37.27 & 3/12/2012 & 35.95 & 1.3 \\
\hline 12S01W33BAA1 & 333718 & 911205 & $3 / 13 / 2008$ & 25.21 & $3 / 12 / 2012$ & 7.39 & 17.8 \\
\hline 13S02W17ADA1 & 333421 & 911858 & $4 / 1 / 2008$ & 46 & $3 / 27 / 2012$ & 47.2 & -1.2 \\
\hline 13S02W27CAC1 & 333224 & 911735 & $3 / 12 / 2008$ & 32.43 & $3 / 12 / 2012$ & 33.92 & -1.5 \\
\hline 13S04W09ACD1 & 333512 & 913034 & $3 / 17 / 2008$ & 20 & 4/9/2012 & 30 & -10.0 \\
\hline 13S05W29ADA1 & 333248 & 913747 & $3 / 12 / 2008$ & 46.85 & 3/12/2012 & 41.6 & 5.3 \\
\hline 13S06W21DAA1 & 333324 & 914258 & $3 / 17 / 2008$ & 72 & 3/27/2012 & 75 & -3.0 \\
\hline 14S04W03ADD1 & 333050 & 912929 & $3 / 17 / 2008$ & 28 & $3 / 27 / 2012$ & 33 & -5.0 \\
\hline 14S04W05CBC1 & 333042 & 913226 & $3 / 17 / 2008$ & 20 & 3/27/2012 & 17 & 3.0 \\
\hline \multicolumn{8}{|c|}{ Greene County } \\
\hline 16N03E03BA1 & 360316 & 904516 & $4 / 9 / 2008$ & 33.17 & $5 / 2 / 2012$ & 36.38 & -3.2 \\
\hline 16N03E05BBB1 & 360316 & 904750 & $4 / 17 / 2008$ & 32.6 & $4 / 2 / 2012$ & 35.9 & -3.3 \\
\hline 16N03E16DDD1 & 360049 & 904547 & $4 / 17 / 2008$ & 28.1 & $4 / 2 / 2012$ & 37 & -8.9 \\
\hline 16N06E09ABB1 & 360215 & 902651 & $4 / 7 / 2008$ & 40.2 & $4 / 3 / 2012$ & 37.8 & 2.4 \\
\hline 16N06E21BAA1 & 360031 & 902705 & $4 / 7 / 2008$ & 27.6 & 4/3/2012 & 35 & -7.4 \\
\hline 17N03E02DCC1 & 360806 & 904352 & $4 / 17 / 2008$ & 30.8 & $4 / 2 / 2012$ & 45.6 & -14.8 \\
\hline 17N04E07AD1 & 360718 & 904122 & $4 / 17 / 2008$ & 38.1 & 4/2/2012 & 43.3 & -5.2 \\
\hline 17N04E28DAA1 & 360431 & 903917 & $4 / 8 / 2008$ & 87.26 & $3 / 14 / 2012$ & 89.79 & -2.5 \\
\hline 17N06E15ABC1 & 360631 & 902546 & $4 / 17 / 2008$ & 30.9 & 4/3/2012 & 36.1 & -5.2 \\
\hline
\end{tabular}


Appendix 2. Difference in water levels measured from 2008 to 2012 in the Mississippi River Valley alluvial aquifer in eastern Arkansas.-Continued

[Horizontal coordinate information is referenced to the North American Datum of 1983 (NAD 83)]

\begin{tabular}{|c|c|c|c|c|c|c|c|}
\hline $\begin{array}{l}\text { Station } \\
\text { name }\end{array}$ & $\begin{array}{l}\text { Latitude } \\
\text { (degrees, } \\
\text { minutes, } \\
\text { seconds) }\end{array}$ & $\begin{array}{c}\text { Longitude } \\
\text { (degrees, } \\
\text { minutes, } \\
\text { seconds) }\end{array}$ & $\begin{array}{c}2008 \text { Water- } \\
\text { level date }\end{array}$ & $\begin{array}{c}2008 \text { Depth } \\
\text { to water } \\
\text { (feet below land- } \\
\text { surface datum) }\end{array}$ & $\begin{array}{l}2012 \text { Water- } \\
\text { level date }\end{array}$ & $\begin{array}{c}2012 \text { Depth } \\
\text { to water } \\
\text { (feet below land- } \\
\text { surface datum) }\end{array}$ & $\begin{array}{c}\text { Water-level } \\
\text { difference } \\
2008 \text { to } 2012 \\
\text { (feet) }\end{array}$ \\
\hline \multicolumn{8}{|c|}{ Greene County-Continued } \\
\hline 17N07E01BBA1 & 360832 & 901724 & $4 / 7 / 2008$ & 5.8 & $4 / 3 / 2012$ & 5.1 & 0.7 \\
\hline 17N07E18ABB1 & 360638 & 902235 & 4/9/2008 & 7.85 & $5 / 2 / 2012$ & 15.36 & -7.5 \\
\hline 18N04E04AAC1 & 361356 & 903854 & $4 / 17 / 2008$ & 31.3 & $4 / 2 / 2012$ & 33.8 & -2.5 \\
\hline 18N04E21CBD1 & 361052 & 903725 & $4 / 9 / 2008$ & 58.57 & $5 / 2 / 2012$ & 58.65 & -0.1 \\
\hline 18N06E23ABB1 & 361109 & 902402 & $4 / 17 / 2008$ & 15.4 & 4/3/2012 & 14.9 & 0.5 \\
\hline 18N07E05DAB1 & 361316 & 902025 & $4 / 7 / 2008$ & 12.2 & 4/3/2012 & 14.1 & -1.9 \\
\hline 19N03E33DDD1 & 361418 & 904516 & $4 / 17 / 2008$ & 36.5 & 4/2/2012 & 40.6 & -4.1 \\
\hline \multicolumn{8}{|c|}{ Independence County } \\
\hline 12N04W14DD1 & 353929 & 912236 & $4 / 16 / 2008$ & 10.54 & $5 / 2 / 2012$ & 22.03 & -11.5 \\
\hline 12N04W34CBB1 & 353720 & 912513 & 4/16/2008 & 4.47 & $5 / 2 / 2012$ & 20.83 & -16.4 \\
\hline \multicolumn{8}{|c|}{ Jackson County } \\
\hline 09N01W22ADD1 & 352332 & 910433 & $4 / 15 / 2008$ & 63.04 & 4/5/2012 & 62.74 & 0.3 \\
\hline 09N02W32CBB1 & 352152 & 911348 & $4 / 15 / 2008$ & 30.39 & 4/5/2012 & 28.95 & 1.4 \\
\hline 10N02W29ABB1 & 352829 & 911312 & $4 / 15 / 2008$ & 28.47 & 4/5/2012 & 26.64 & 1.8 \\
\hline 11N01W26AAD1 & 353330 & 910323 & $4 / 15 / 2008$ & 68.29 & $4 / 26 / 2012$ & 70.59 & -2.3 \\
\hline 03S09W06DDA1 & 342840 & 920037 & $3 / 18 / 2008$ & 37.02 & 3/19/2012 & 39.46 & -2.4 \\
\hline 03S09W14BCD1 & 342712 & 915712 & 3/31/2008 & 51 & 4/3/2012 & 72.8 & -21.8 \\
\hline 03S09W22AAA1 & 342640 & 915728 & 3/31/2008 & 43 & 4/3/2012 & 42 & 1.0 \\
\hline 03S09W29CBD1 & 342517 & 920023 & $3 / 18 / 2008$ & 27.74 & 3/19/2012 & 27.08 & 0.7 \\
\hline 03S09W36ACC1 & 342428 & 915555 & 3/31/2008 & 29 & 3/29/2012 & 38.9 & -9.9 \\
\hline 03S10W35BBC1 & 342449 & 920358 & 3/31/2008 & 8.5 & 4/3/2012 & 11 & -2.5 \\
\hline 04S07W35DDB1 & 341836 & 914347 & 3/31/2008 & 28.8 & 3/29/2012 & 30.6 & -1.8 \\
\hline 04S08W13DCB1 & 342123 & 914926 & $3 / 18 / 2008$ & 47.99 & 3/19/2012 & 47.8 & 0.2 \\
\hline 04S09W02CBD1 & 342325 & 915717 & 3/31/2008 & 26.6 & 3/29/2012 & 34.9 & -8.3 \\
\hline 05S08W12DAA1 & 341712 & 914907 & $3 / 18 / 2008$ & 16.15 & 3/19/2012 & 18.05 & -1.9 \\
\hline 06S05W15BCA1 & 341023 & 913245 & $3 / 18 / 2008$ & 18.22 & 3/13/2012 & 16.69 & 1.5 \\
\hline 06S06W23AAD1 & 341007 & 913712 & $3 / 18 / 2008$ & 19.02 & 3/13/2012 & 19.37 & -0.4 \\
\hline 06S07W14BAA1 & 341125 & 914426 & $3 / 18 / 2008$ & 15.25 & 3/13/2012 & 15.69 & -0.4 \\
\hline 07S08W06BAA1 & 340859 & 915647 & $3 / 18 / 2008$ & 19.07 & 3/13/2012 & 20.62 & -1.6 \\
\hline
\end{tabular}


Appendix 2. Difference in water levels measured from 2008 to 2012 in the Mississippi River Valley alluvial aquifer in eastern Arkansas.-Continued

[Horizontal coordinate information is referenced to the North American Datum of 1983 (NAD 83)]

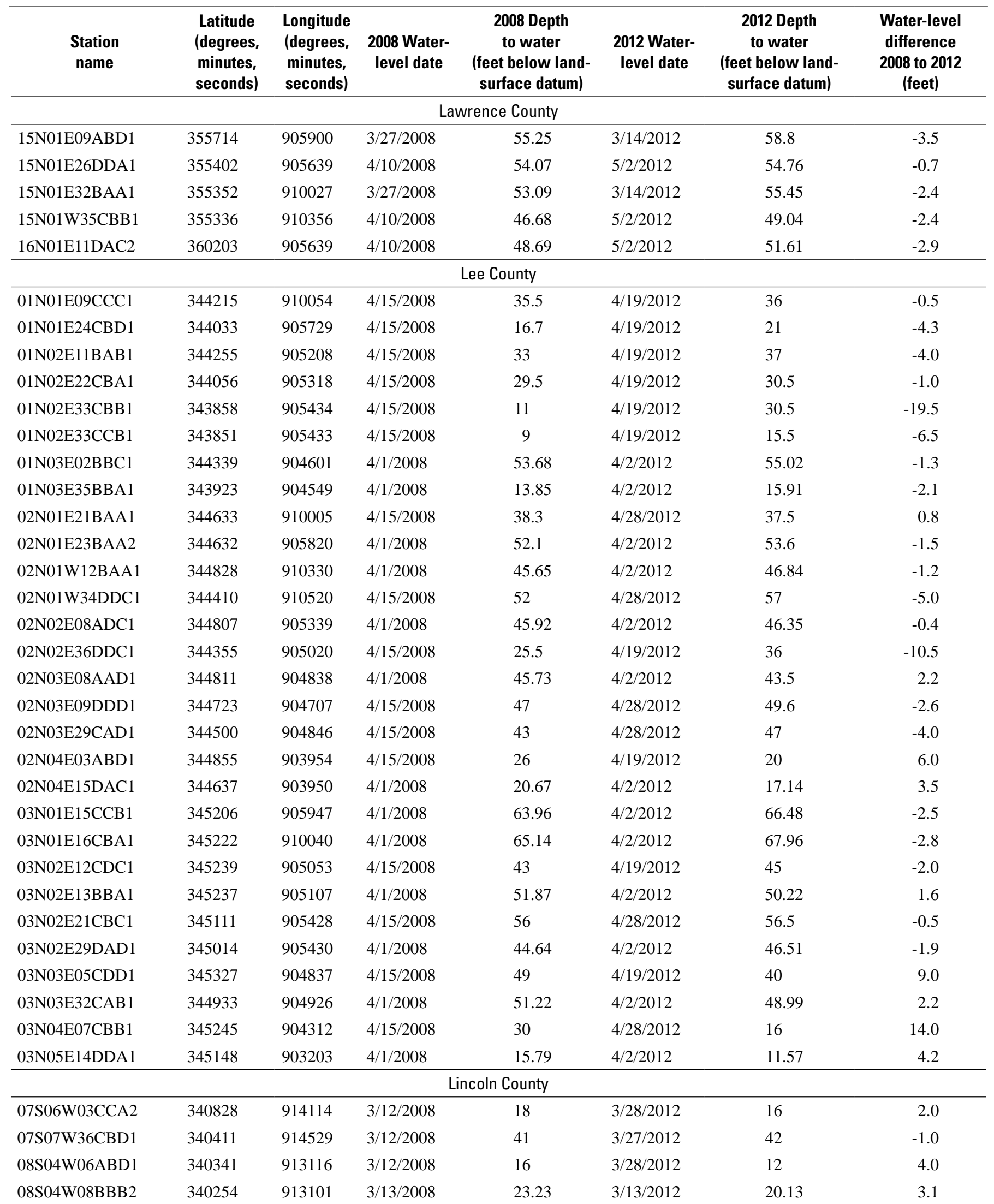


Appendix 2. Difference in water levels measured from 2008 to 2012 in the Mississippi River Valley alluvial aquifer in eastern Arkansas.-Continued

[Horizontal coordinate information is referenced to the North American Datum of 1983 (NAD 83)]

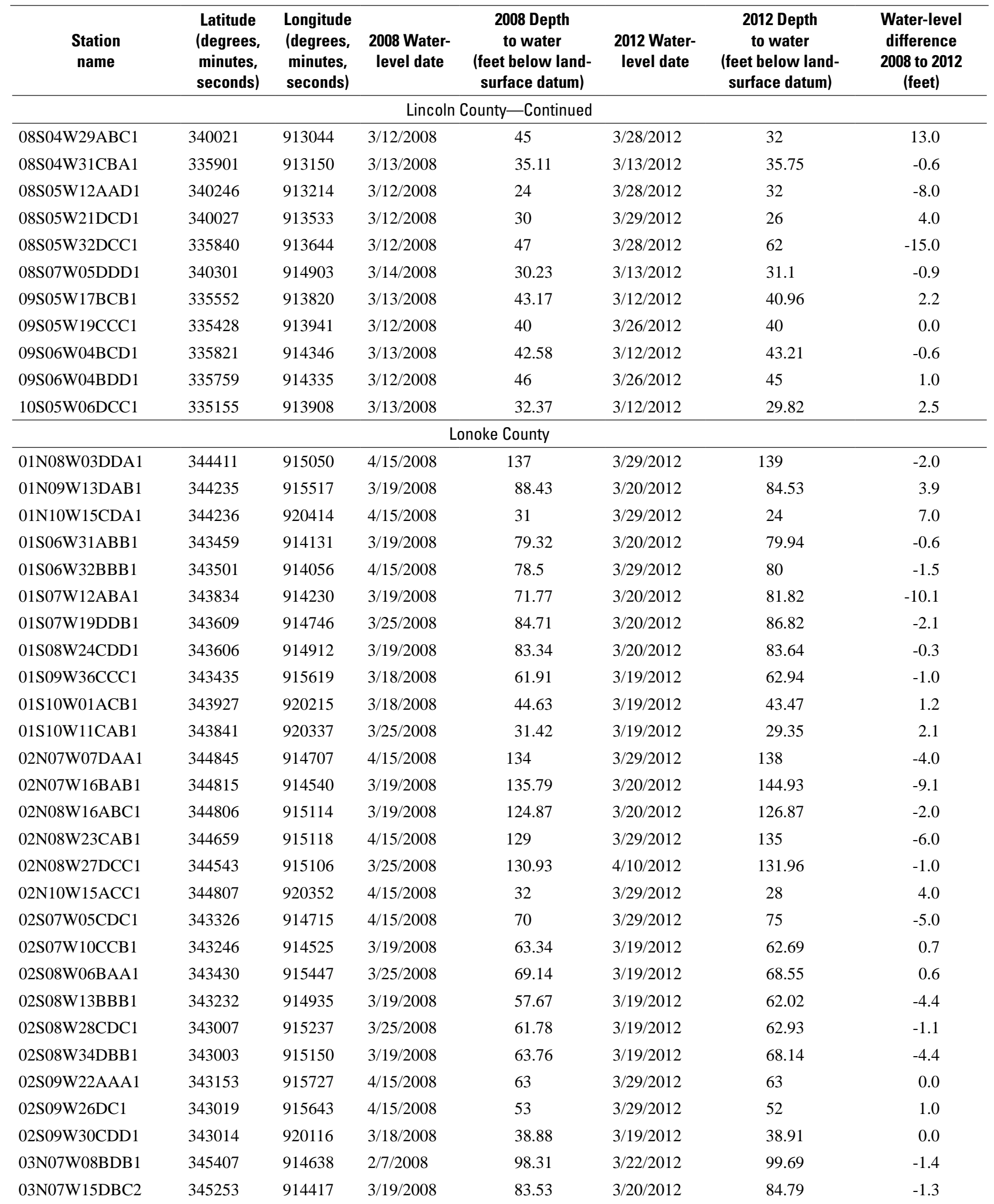


Appendix 2. Difference in water levels measured from 2008 to 2012 in the Mississippi River Valley alluvial aquifer in eastern Arkansas.-Continued

[Horizontal coordinate information is referenced to the North American Datum of 1983 (NAD 83)]

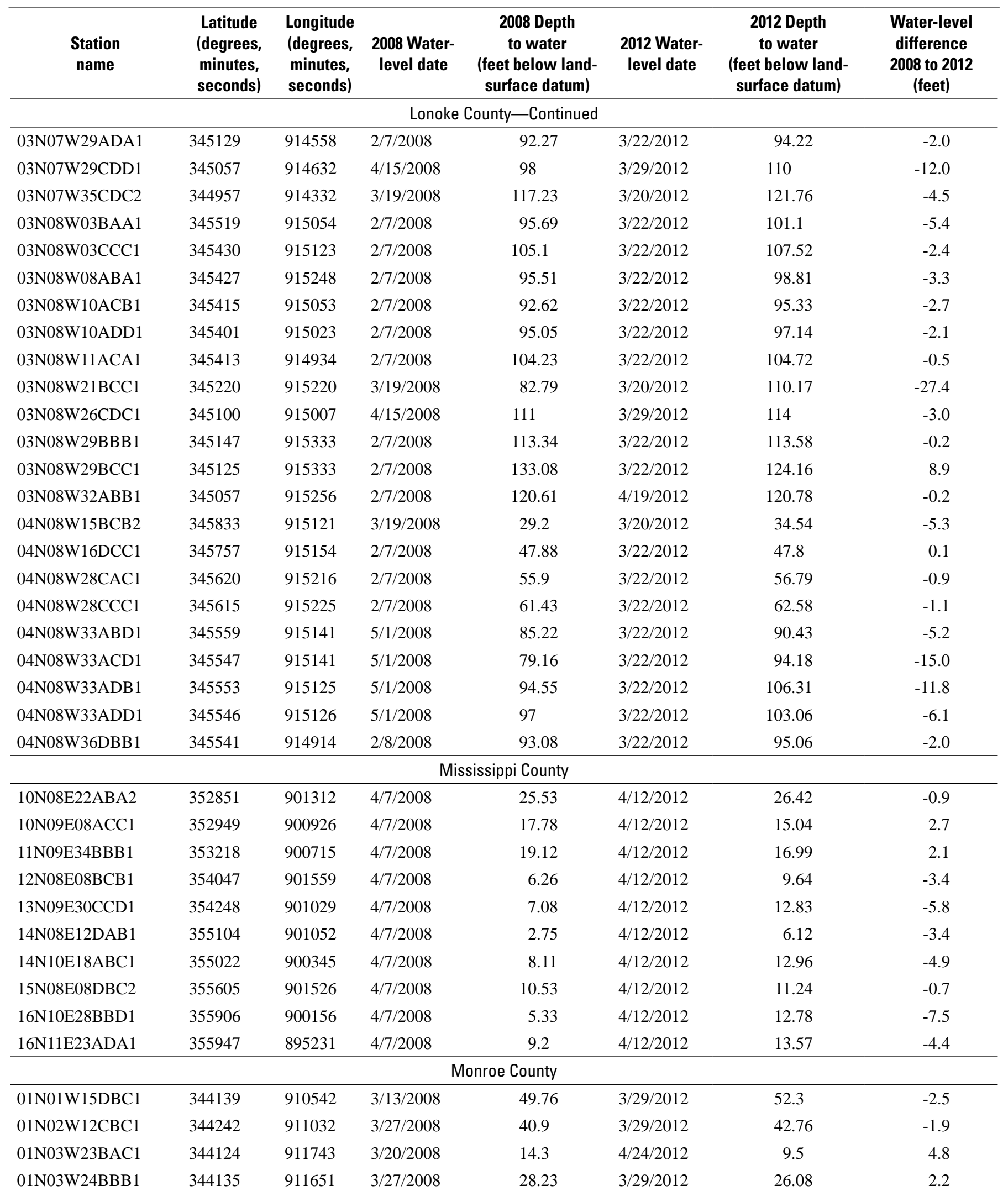


Appendix 2. Difference in water levels measured from 2008 to 2012 in the Mississippi River Valley alluvial aquifer in eastern Arkansas.-Continued

[Horizontal coordinate information is referenced to the North American Datum of 1983 (NAD 83)]

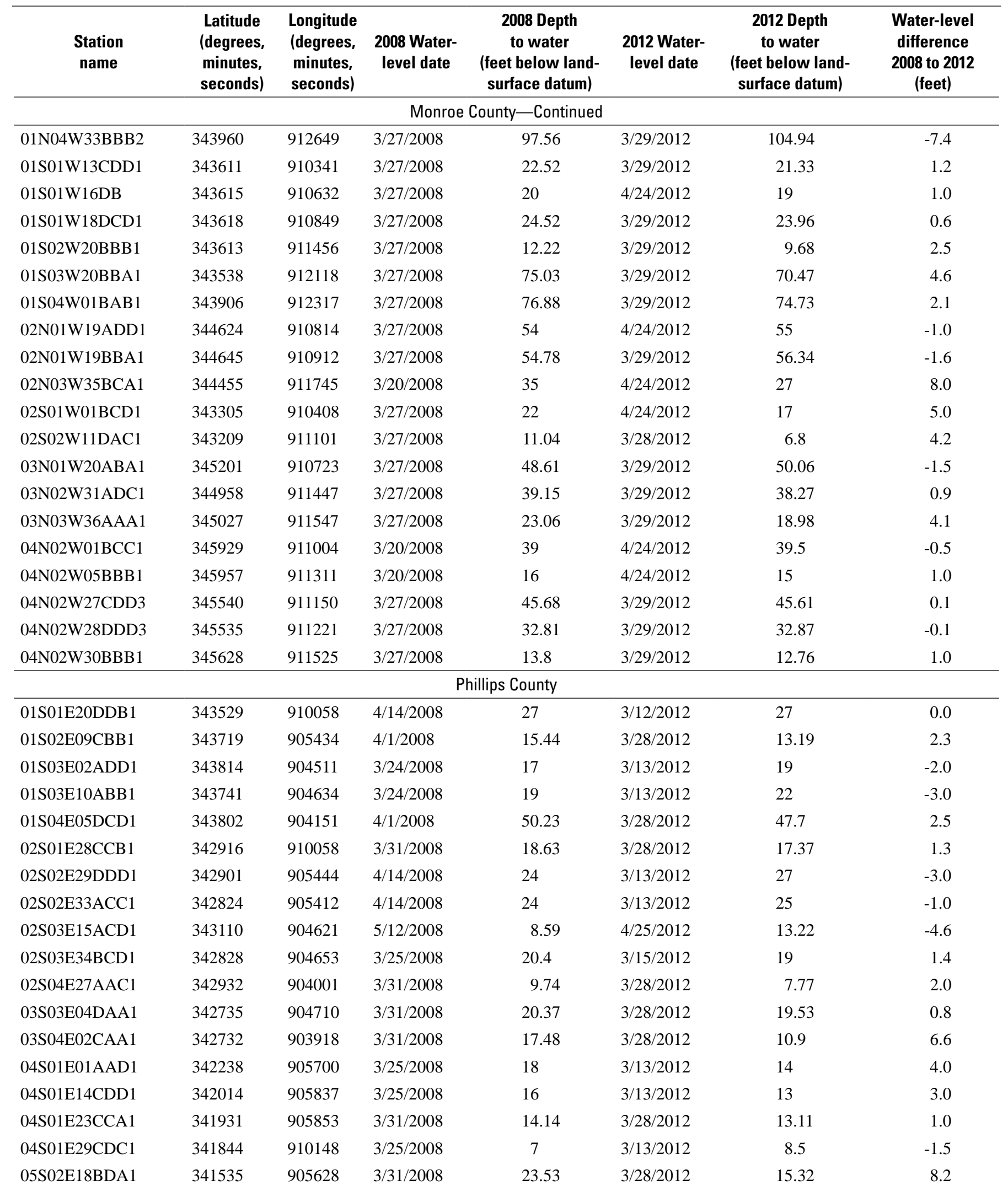


Appendix 2. Difference in water levels measured from 2008 to 2012 in the Mississippi River Valley alluvial aquifer in eastern Arkansas.-Continued

[Horizontal coordinate information is referenced to the North American Datum of 1983 (NAD 83)]

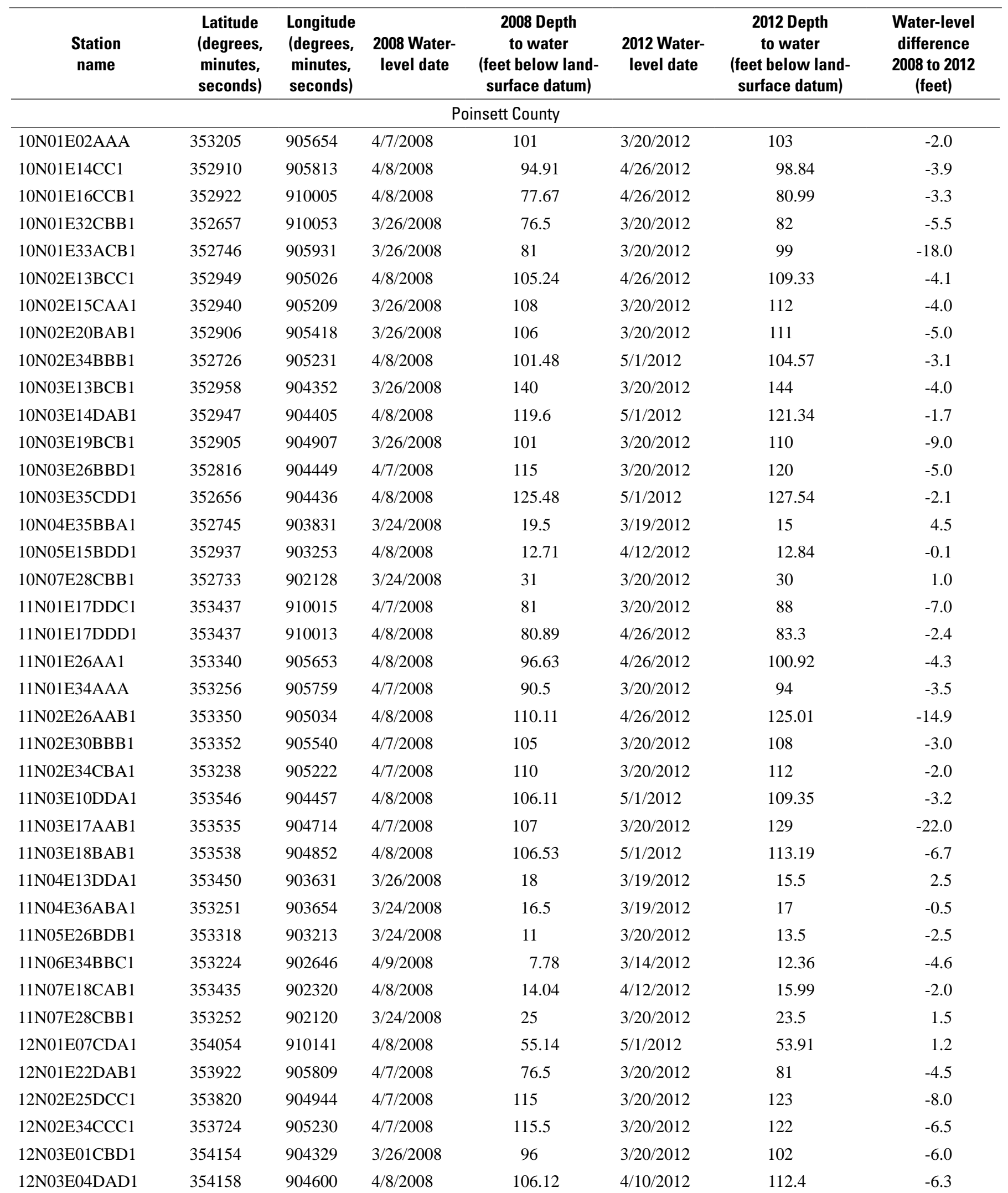


Appendix 2. Difference in water levels measured from 2008 to 2012 in the Mississippi River Valley alluvial aquifer in eastern Arkansas.-Continued

[Horizontal coordinate information is referenced to the North American Datum of 1983 (NAD 83)]

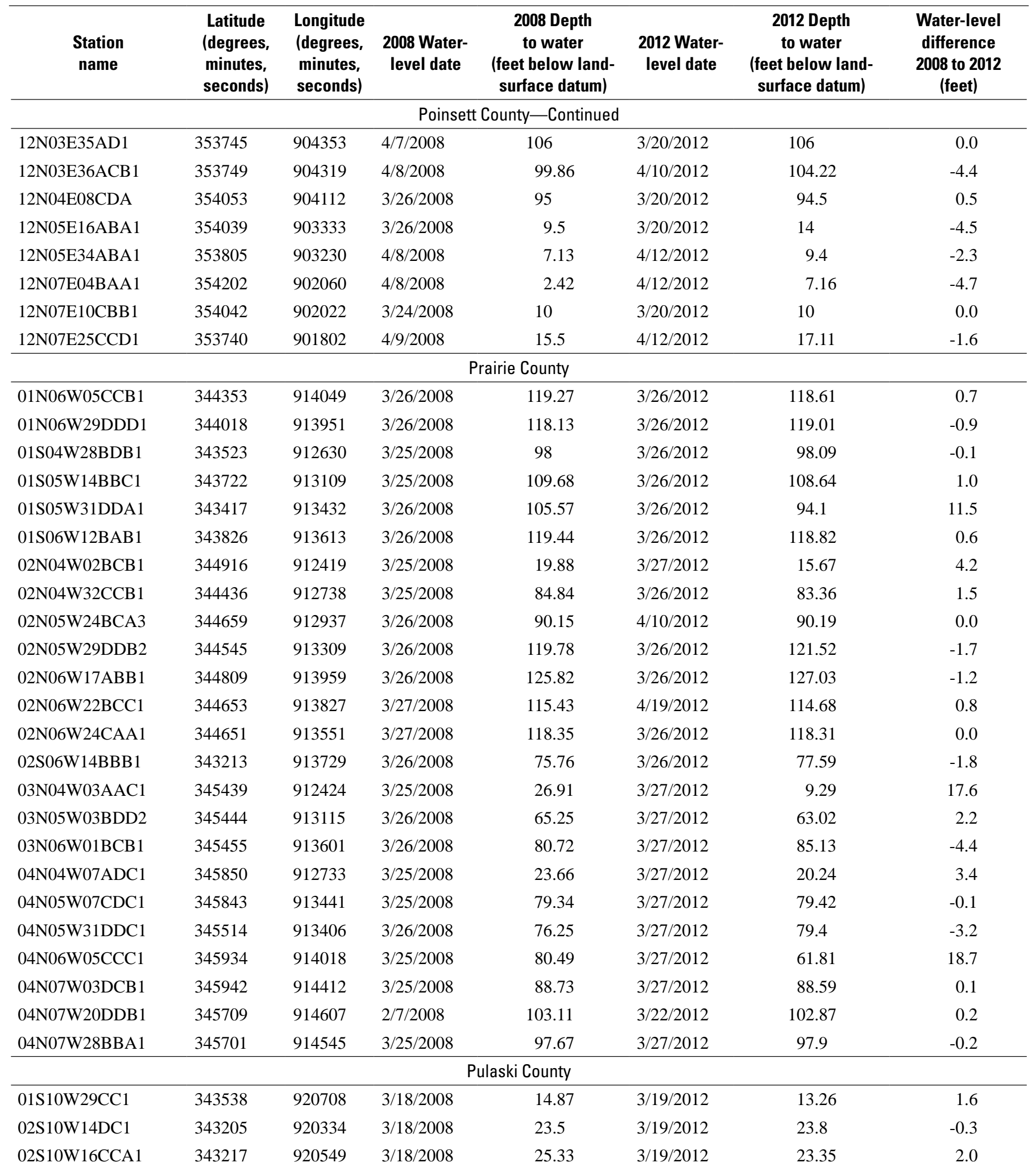


Appendix 2. Difference in water levels measured from 2008 to 2012 in the Mississippi River Valley alluvial aquifer in eastern Arkansas.-Continued

[Horizontal coordinate information is referenced to the North American Datum of 1983 (NAD 83)]

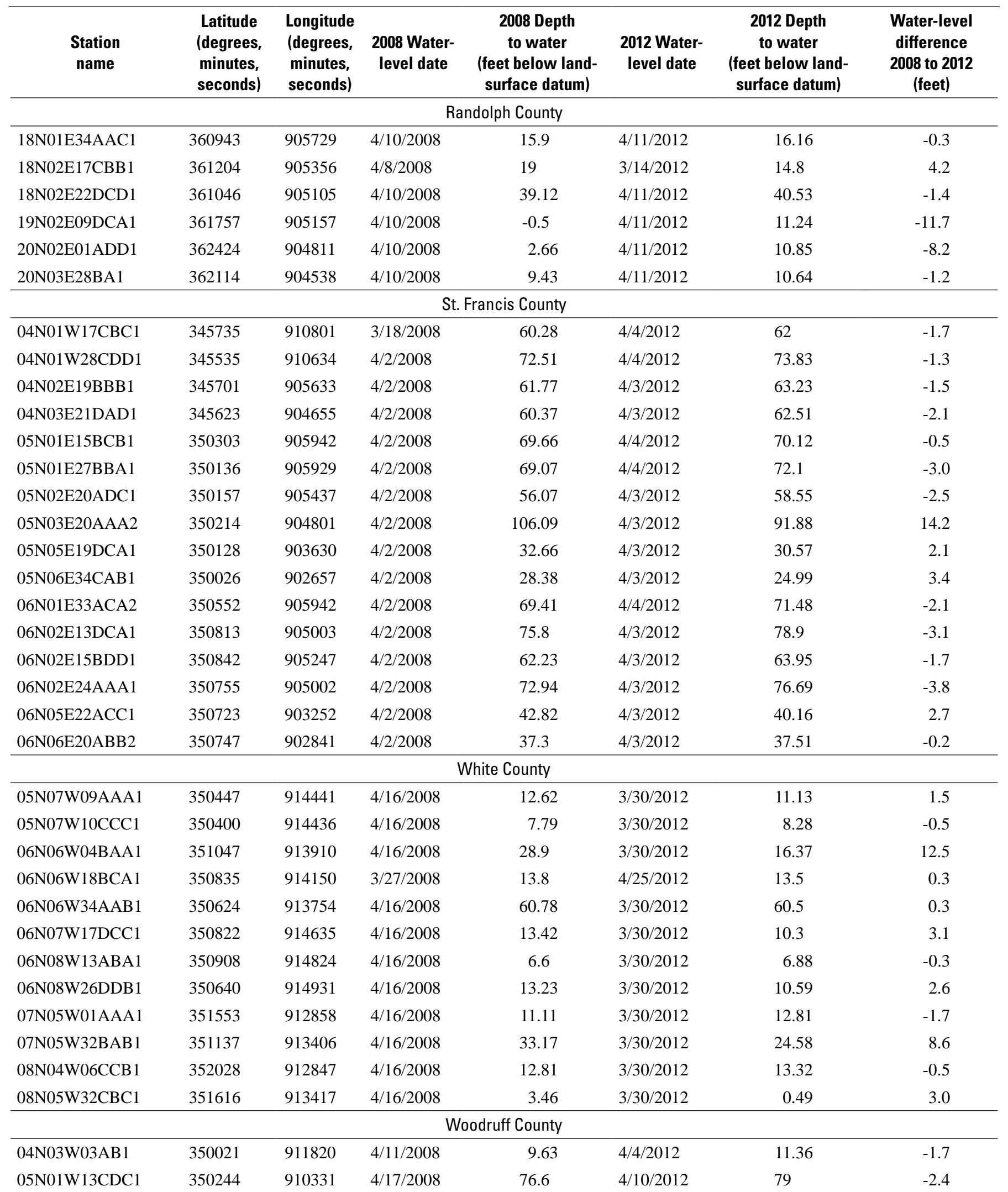


Appendix 2. Difference in water levels measured from 2008 to 2012 in the Mississippi River Valley alluvial aquifer in eastern Arkansas.-Continued

[Horizontal coordinate information is referenced to the North American Datum of 1983 (NAD 83)]

\begin{tabular}{|c|c|c|c|c|c|c|c|}
\hline $\begin{array}{c}\text { Station } \\
\text { name }\end{array}$ & $\begin{array}{l}\text { Latitude } \\
\text { (degrees, } \\
\text { minutes, } \\
\text { seconds) }\end{array}$ & $\begin{array}{c}\text { Longitude } \\
\text { (degrees, } \\
\text { minutes, } \\
\text { seconds) }\end{array}$ & $\begin{array}{l}2008 \text { Water- } \\
\text { level date }\end{array}$ & $\begin{array}{c}2008 \text { Depth } \\
\text { to water } \\
\text { (feet below land- } \\
\text { surface datum) }\end{array}$ & $\begin{array}{l}2012 \text { Water- } \\
\text { level date }\end{array}$ & $\begin{array}{c}2012 \text { Depth } \\
\text { to water } \\
\text { (feet below land- } \\
\text { surface datum) }\end{array}$ & $\begin{array}{c}\text { Water-level } \\
\text { difference } \\
2008 \text { to } 2012 \\
\text { (feet) }\end{array}$ \\
\hline \multicolumn{8}{|c|}{ Woodruff County-Continued } \\
\hline 05N01W31CCC1 & 350106 & 910900 & $4 / 17 / 2008$ & 61.2 & $4 / 10 / 2012$ & 62 & -0.8 \\
\hline 05N02W20DCB1 & 350208 & 911356 & $4 / 11 / 2008$ & 11.87 & $4 / 4 / 2012$ & 12.88 & -1.0 \\
\hline 05N04W12DBA1 & 350427 & 912211 & $4 / 15 / 2008$ & 2.94 & 4/4/2012 & 4.35 & -1.4 \\
\hline 06N01W06BAB1 & 351048 & 910835 & $4 / 11 / 2008$ & 36.73 & 4/5/2012 & 33.21 & 3.5 \\
\hline 06N01W11AAB1 & 350944 & 910354 & 3/27/2008 & 63.72 & 4/4/2012 & 64.92 & -1.2 \\
\hline 06N02W19AAA1 & 350802 & 911419 & $4 / 17 / 2008$ & 45.9 & $4 / 10 / 2012$ & 47.5 & -1.6 \\
\hline 07N03W31BBA1 & 351152 & 912103 & $4 / 17 / 2008$ & 7.7 & $4 / 10 / 2012$ & 8 & -0.3 \\
\hline 08N01W06DDD1 & 352028 & 910747 & $4 / 11 / 2008$ & 46.14 & 4/5/2012 & 43.49 & 2.6 \\
\hline 08N02W27DDB1 & 351711 & 911107 & $4 / 17 / 2008$ & 27.5 & $4 / 10 / 2012$ & 26 & 1.5 \\
\hline 08N02W31DDD1 & 351611 & 911411 & $4 / 11 / 2008$ & 1.66 & 4/4/2012 & 4.63 & -3.0 \\
\hline 08N03W04BBB1 & 352128 & 911919 & $3 / 27 / 2008$ & 17.62 & 4/5/2012 & 13.58 & 4.0 \\
\hline 08N03W31AAD1 & 351655 & 912028 & $4 / 15 / 2008$ & 22.78 & 4/5/2012 & 18.82 & 4.0 \\
\hline 09N03W28ABB1 & 352310 & 911845 & $4 / 17 / 2008$ & 17.6 & 4/10/2012 & 15 & 2.6 \\
\hline 09N03W29AAD1 & 352258 & 911921 & $4 / 15 / 2008$ & 18.9 & 4/5/2012 & 17.93 & 1.0 \\
\hline 09N03W32ACA1 & 352205 & 911936 & $4 / 17 / 2008$ & 16.9 & 4/10/2012 & 15 & 1.9 \\
\hline
\end{tabular}


Appendix 3. Specific conductance, temperature, pH, and chloride data from wells completed in the Mississippi River Valley alluvial aquifer in eastern Arkansas, summmer 2012.

[Horizontal coordinate information is referenced to the North American Datum of 1983 (NAD 83); $\mu \mathrm{S} / \mathrm{cm}$ at $25^{\circ} \mathrm{C}$, microsiemens per centimeter at 25 degrees Celsius; mg/L, milligrams per liter; --, no data]

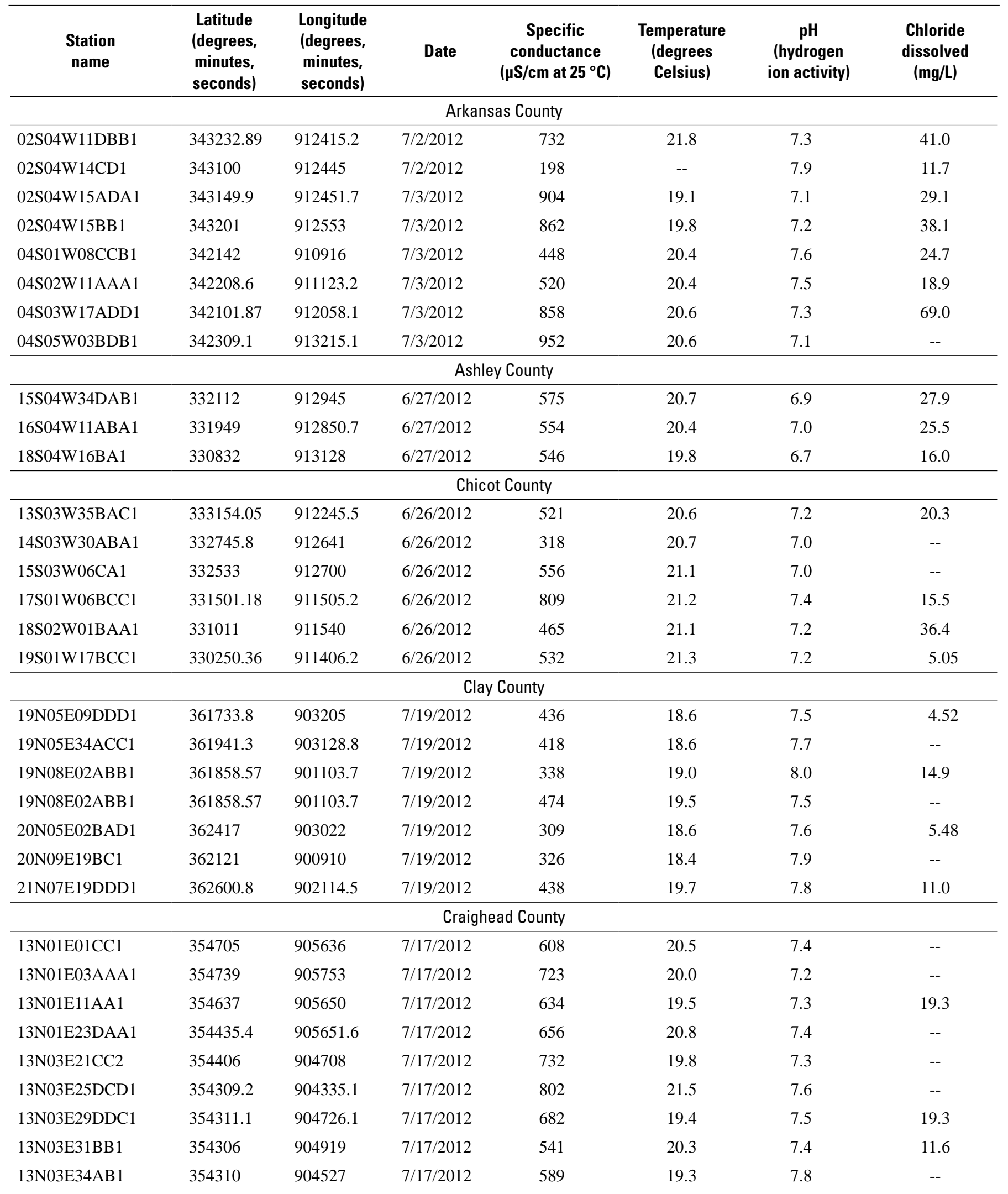


Appendix 3. Specific conductance, temperature, $\mathrm{pH}$, and chloride data from wells completed in the Mississippi River Valley alluvial aquifer in eastern Arkansas, summmer 2012.-Continued

[Horizontal coordinate information is referenced to the North American Datum of 1983 (NAD 83); $\mu \mathrm{S} / \mathrm{cm}$ at $25{ }^{\circ} \mathrm{C}$, microsiemens per centimeter at 25 degrees Celsius; mg/L, milligrams per liter; --, no data]

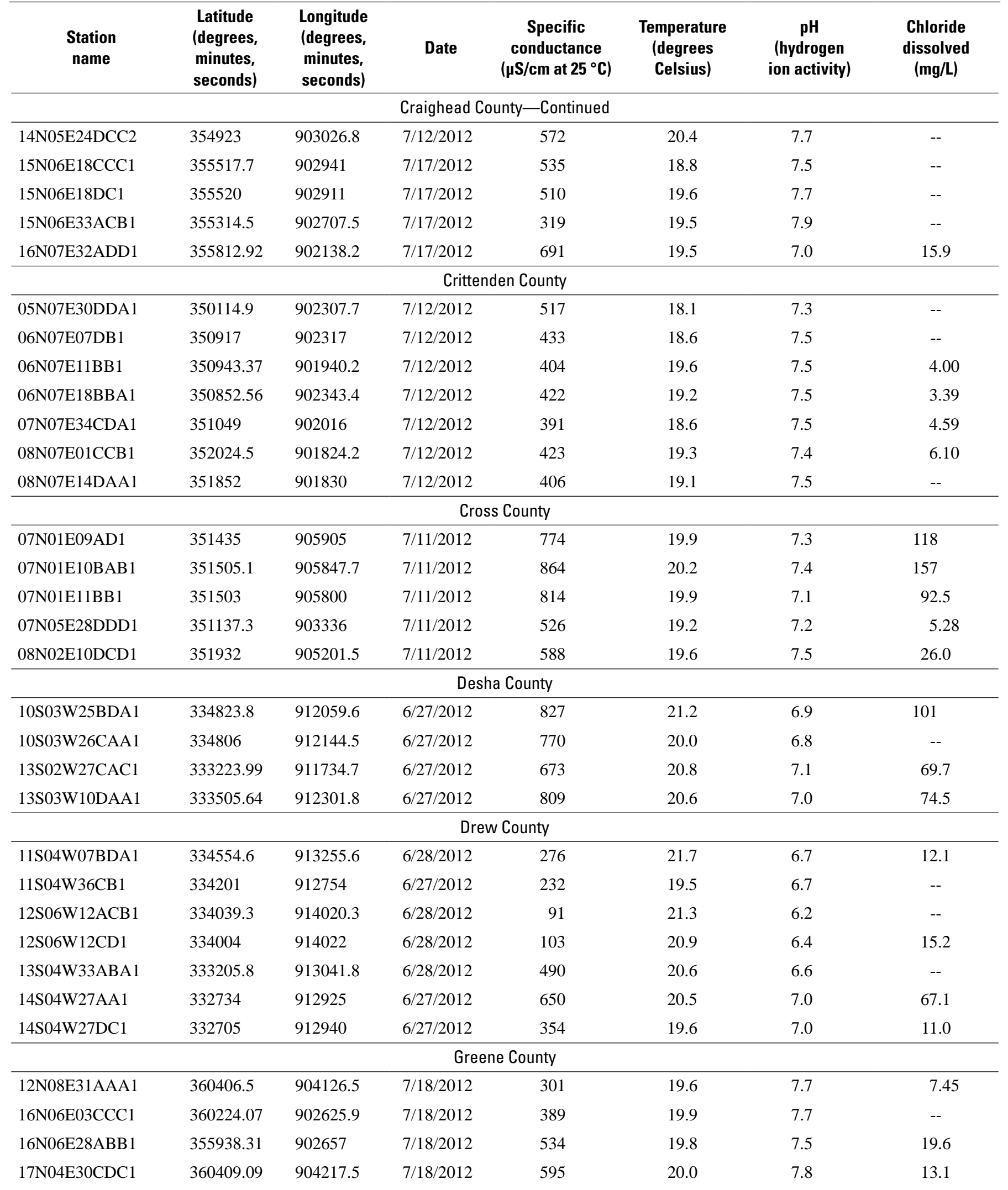


Appendix 3. Specific conductance, temperature, $\mathrm{pH}$, and chloride data from wells completed in the Mississippi River Valley alluvial aquifer in eastern Arkansas, summmer 2012.-Continued

[Horizontal coordinate information is referenced to the North American Datum of 1983 (NAD 83); $\mu \mathrm{S} / \mathrm{cm}$ at $25^{\circ} \mathrm{C}$, microsiemens per centimeter at 25 degrees Celsius; mg/L, milligrams per liter; --, no data]

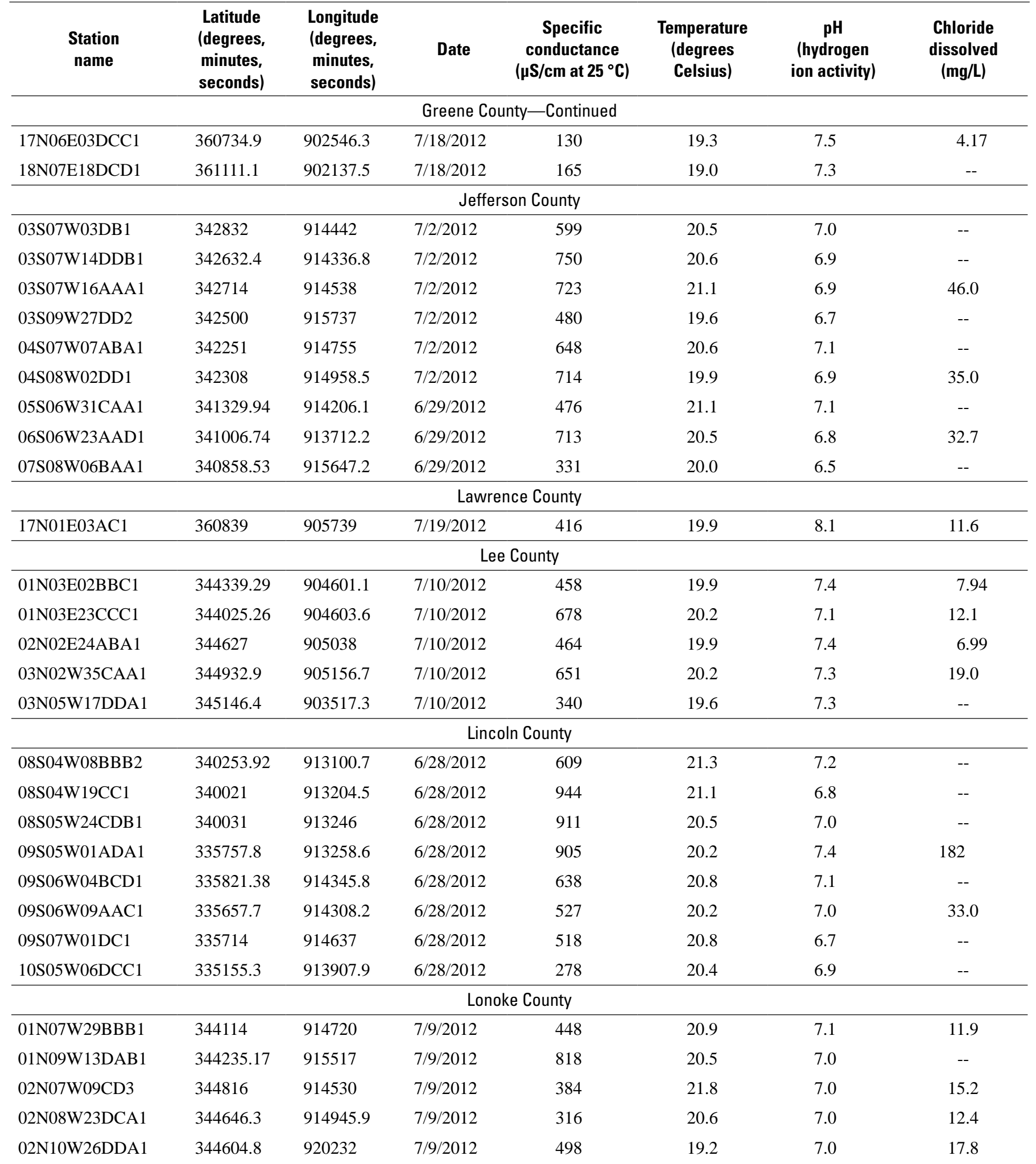


Appendix 3. Specific conductance, temperature, $\mathrm{pH}$, and chloride data from wells completed in the Mississippi River Valley alluvial aquifer in eastern Arkansas, summmer 2012. - Continued

[Horizontal coordinate information is referenced to the North American Datum of 1983 (NAD 83); $\mu \mathrm{S} / \mathrm{cm}$ at $25^{\circ} \mathrm{C}$, microsiemens per centimeter at 25 degrees Celsius; mg/L, milligrams per liter; --, no data]

\begin{tabular}{|c|c|c|c|c|c|c|c|}
\hline $\begin{array}{c}\text { Station } \\
\text { name }\end{array}$ & $\begin{array}{l}\text { Latitude } \\
\text { (degrees, } \\
\text { minutes, } \\
\text { seconds) }\end{array}$ & $\begin{array}{l}\text { Longitude } \\
\text { (degrees, } \\
\text { minutes, } \\
\text { seconds) }\end{array}$ & Date & $\begin{array}{c}\text { Specific } \\
\text { conductance } \\
\left(\mu \mathrm{S} / \mathrm{cm} \text { at } 25^{\circ} \mathrm{C}\right)\end{array}$ & $\begin{array}{c}\text { Temperature } \\
\text { (degrees } \\
\text { Celsius) }\end{array}$ & $\begin{array}{c}\text { pH } \\
\text { (hydrogen } \\
\text { ion activity) }\end{array}$ & $\begin{array}{c}\text { Chloride } \\
\text { dissolved } \\
\text { (mg/L) }\end{array}$ \\
\hline \multicolumn{8}{|c|}{ Mississippi County } \\
\hline 11N09E04BDA1 & 353627.7 & 900802 & $7 / 18 / 2012$ & 551 & 19.5 & 7.6 & 9.28 \\
\hline 11N09E04CD1 & 353555 & 900809 & 7/18/2012 & 480 & 19.7 & 8.0 & 7.74 \\
\hline 12N08E33AB2 & 353732 & 901447 & 7/18/2012 & 404 & 21.5 & 8.2 & 4.57 \\
\hline 12N09E34CDC1 & 353642 & 900708 & 7/18/2012 & 528 & 19.5 & 7.5 & -- \\
\hline 14N10E04CDC1 & 355127.9 & 900150.1 & 7/18/2012 & 470 & 19.6 & 7.4 & 6.83 \\
\hline 14N10E07DAC1 & 355050 & 900326.4 & 7/18/2012 & 360 & 20.0 & 7.4 & 5.53 \\
\hline 02N01W19BBA1 & 344645.21 & 910912.4 & 7/5/2012 & 984 & 21.2 & 7.6 & -- \\
\hline 02N02W06AAD1 & 344920 & 911442 & 7/6/2012 & 562 & 20.8 & 7.2 & 36.5 \\
\hline 02S02W11DAC1 & 343208.97 & 911100.5 & 7/5/2012 & 438 & 20.3 & 7.5 & 8.19 \\
\hline 03N02W26AAB1 & 345103 & 911033 & 7/5/2012 & 917 & 20.4 & 7.5 & 143 \\
\hline \multicolumn{8}{|c|}{ Phillips County } \\
\hline 01S01E29DA1 & 343436 & 910059 & $7 / 5 / 2012$ & 624 & 21.0 & 7.5 & -- \\
\hline 02S01E26CAB1 & 342924.4 & 905839.4 & 7/5/2012 & 669 & 20.3 & 7.3 & 12.5 \\
\hline 02S01E28CCB1 & 342916.37 & 910058.1 & 7/5/2012 & 424 & 20.4 & 7.4 & 20.4 \\
\hline 11N02E30BAB1 & 353350 & 905522 & $7 / 16 / 2012$ & 612 & 20.6 & 7.5 & 11.2 \\
\hline \multicolumn{8}{|c|}{ Prairie County } \\
\hline 01N05W20DCB1 & 344118.18 & 913348.7 & $7 / 9 / 2012$ & 564 & 20.4 & 7.5 & 11.0 \\
\hline 01N06W26CDC1 & 344013.9 & 913724.8 & 7/9/2012 & 576 & 21.0 & 7.4 & 20.5 \\
\hline 01N06W30ADC1 & 344050.6 & 914111.4 & 7/9/2012 & 758 & 20.1 & 7.2 & 45.5 \\
\hline 01S06W13CCC1 & 343648.6 & 913638.6 & 7/9/2012 & 726 & 22.4 & 7.0 & -- \\
\hline 02N05W31AA1 & 344537 & 913406 & 7/9/2012 & 776 & 20.4 & 7.4 & 32.8 \\
\hline 04N04W01BAA1 & 350026.3 & 912238.2 & $7 / 12 / 2012$ & 422 & 20.4 & 7.6 & 41.4 \\
\hline \multicolumn{8}{|c|}{ Pulaski County } \\
\hline 01S10W26DAC1 & 343553 & 920304.1 & $7 / 9 / 2012$ & 483 & 19.4 & 6.8 & 18.3 \\
\hline 01S10W29CC1 & 343537.78 & 920707.6 & $6 / 25 / 2012$ & 770 & 20.8 & 6.9 & 11.1 \\
\hline 02S10W15CDD1 & 343204 & 920430 & $6 / 25 / 2012$ & 819 & 19.8 & 6.9 & -- \\
\hline
\end{tabular}


Appendix 3. Specific conductance, temperature, $\mathrm{pH}$, and chloride data from wells completed in the Mississippi River Valley alluvial aquifer in eastern Arkansas, summmer 2012.-Continued

[Horizontal coordinate information is referenced to the North American Datum of 1983 (NAD 83); $\mu \mathrm{S} / \mathrm{cm}$ at $25^{\circ} \mathrm{C}$, microsiemens per centimeter at 25 degrees Celsius; mg/L, milligrams per liter; --, no data]

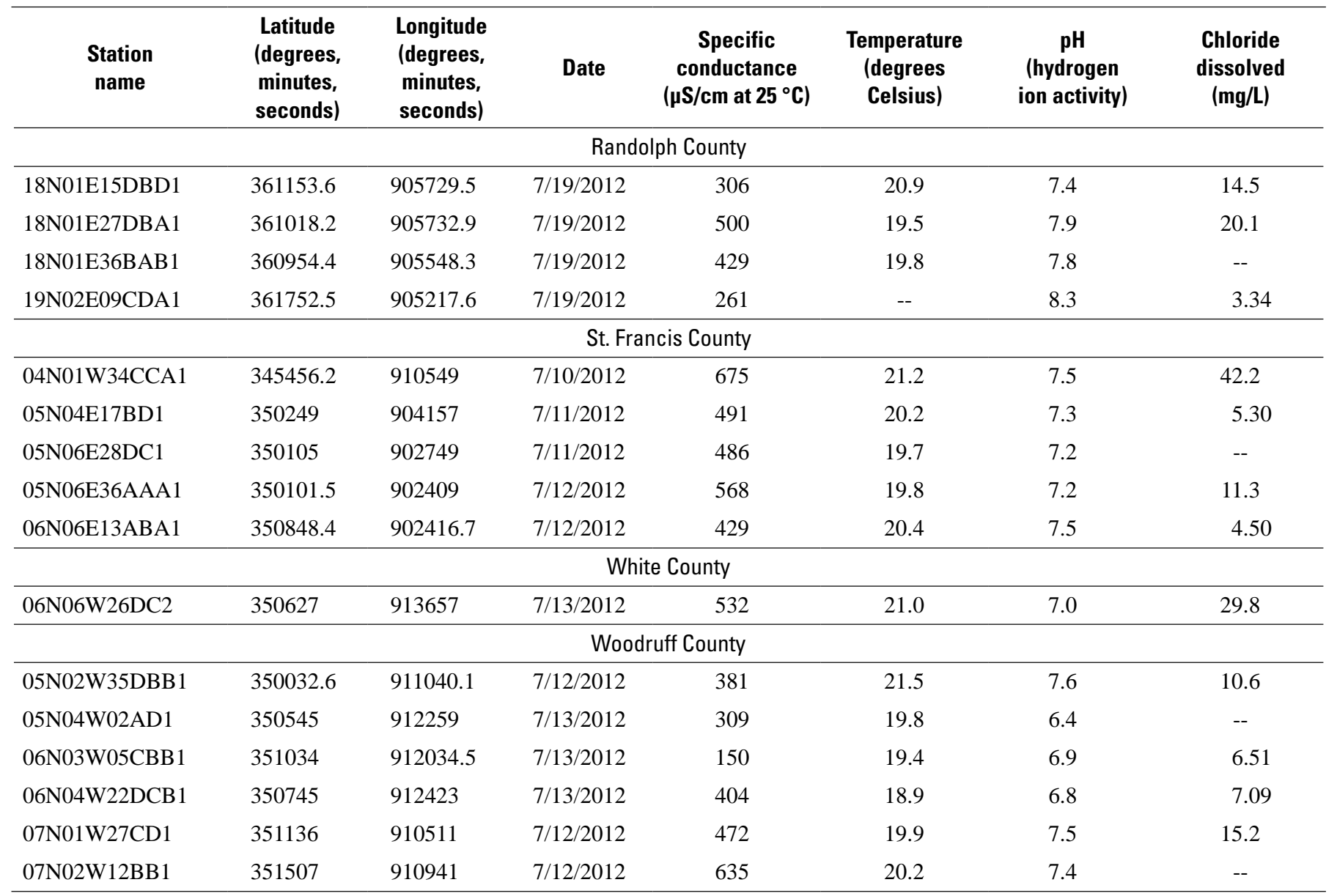


